\title{
Esperanza y la gran historia de nuestro camino: Guía para mentoras de Abriendo Oportunidades
}

Population Council

Follow this and additional works at: https://knowledgecommons.popcouncil.org/departments_sbsr-pgy How does access to this work benefit you? Let us know!

\section{Recommended Citation}

"Esperanza y la gran historia de nuestro camino: Guía para mentoras de Abriendo Oportunidades." Ciudad de Guatemala: Population Council, 2021. 


\section{POPULATION}

coUNCIL

Ideas. Evidence. Impact.
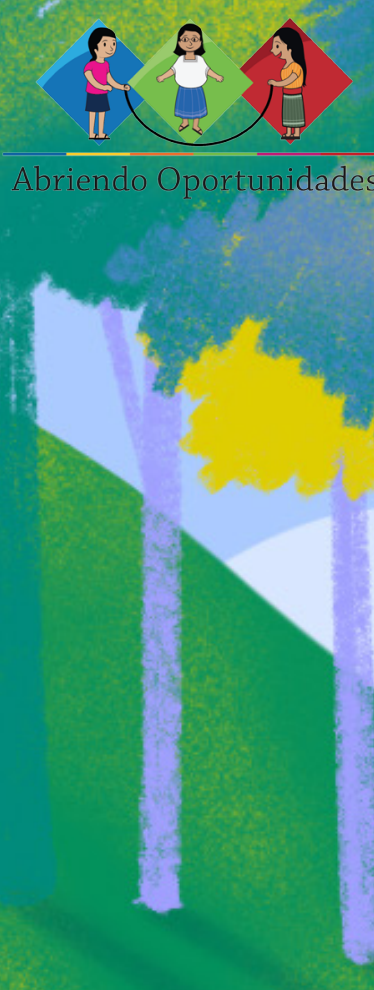
El Population Council enfrenta problemas críticos de salud y desarrollo, desde detener la propagación del VIH hasta mejorar la salud sexual reproductiva y garantizar que los jóvenes lleven una vida plena y productiva. A través de la investigación biomédica, de ciencias sociales y de salud pública en 50 países, trabajamos con nuestros socios para ofrecer soluciones que conduzcan a políticas, programas y tecnologías más efectivas que mejoren vidas en todo el mundo. Establecido en 1952 y con sede en Nueva York, el Council es una organización no gubernamental, sin fines de lucro, gobernada por una junta internacional.

\section{Population Council Guatemala}

19 avenida 0-35 Zona 15, Vista Hermosa 2,

Ciudad de Guatemala, 01015 Guatemala

Tel: +502 2369-0292

popcouncil.org

Texto, diseño y diagramación:

Luis Méndez Salinas y Carmen Lucía Alvarado

Ilustraciones:

Paula Gramajo, Mario Valdez y Leke García

Ciudad de Guatemala, Population Council

(C) 2021 The Population Council, Inc. 


\title{
Esperanza y la gran historia de nuestro camino
}

\author{
Guía para mentoras de Abriendo Oportunidades ${ }^{\circledR}$
}

\section{Introducción}

Esperanza es una niña llena de preguntas. Sus estudios en la escuela, su relación diaria con las personas que le rodean, las oportunidades y los conocimientos que le ha dado su participación en los grupos de $\mathrm{AO}$, la han hecho pensar mucho. Ella es una niña como todas las que participan semana a semana contigo. Por eso, creemos que es importante que la conozcas y que compartas con las niñas de tu comunidad todas estas preguntas.

Son preguntas simples que requieren respuestas complejas, y por eso es muy útil tratar de responderlas entre todas. Tienen que ver con ella misma, con su grupo familiar, con su comunidad, su municipio, su departamento, su país; con la historia de todos ellos. Estas preguntas son las que trataremos de responder durante las 18 sesiones que integran esta guía:

- ¿̇Quién soy?

- ¿̇Por qué estoy acá?

- ¿De dónde vengo?

- ¿̇Por qué es así el lugar donde vivo?

- ¿Por qué son así las personas que veo todos los días?

Trata de tener estas preguntas presentes durante todo el proceso, pues haremos un recorrido largo y profundo por la historia de los lugares que habitamos y por la historia de los grupos humanos que le han dado origen a la sociedad actual. Haremos un viaje en el tiempo y conoceremos información importante para situarnos en el aquí y el ahora.

En términos generales, cada una de las 18 sesiones que forman esta guía está integrada por los siguientes contenidos:

\section{Nuestras grandes preguntas}

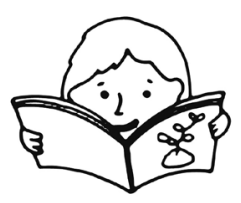

Tu grupo de Abriendo Oportunidades ${ }^{\circledR}$ es un punto de encuentro, un lugar y un momento en que las niñas sienten la confianza y la seguridad de platicar sus cosas, de compartir con alegría. Por eso, al iniciar cada sesión, es bueno dialogar: pregúntales cómo les va, cómo se sienten,

$$
\text { Guia para mentoras de Abriendo Oportunidades }{ }^{(3)}
$$


qué han hecho en la escuela; cuéntales también cómo ha sido tu día a día. Es importante que se establezca una relación verdadera entre todas las niñas participantes, y el resultado será mucho mejor si tú -como mentora- te involucras y favoreces esa relación.

\section{Los relatos de Esperanza}

En cada sesión te presentaremos un relato de lo que sucede en la vida de Esperanza, de las situaciones de todos los días que la hacen preguntarse cosas. En esta sección iremos abarcando los distintos momentos históricos y sociales que hemos atravesado como país, como comunidad. En ese sentido, las niñas de tu grupo irán reforzando conocimientos que les serán muy útiles en su vida y que se comunican con el aprendizaje que la escuela les brindará en el área de estudios sociales, particularmente en relación con la historia de Guatemala.

\section{Hagamos algo juntas}

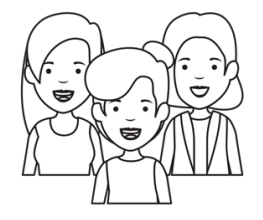

Luego del relato, encontrarás alguna actividad grupal o individual que las niñas de tu grupo deberán realizar, siempre relacionadas con el tema que estemos aprendiendo. Es importante que uses toda tu creatividad para hacer que cada sesión sea distinta, para interesar a las niñas y para que todas la pasen bien mientras aprenden juntas en un espacio seguro. Las actividades que aquí te sugerimos pueden modificarse de acuerdo a las necesidades y a las posibilidades que tú y tu grupo tengan.

\section{Oportunidades en casa}

También encontrarás diversas actividades que las niñas deberán realizar en casa. Tú se las comunicarás al final de cada sesión, y recuerda empezar las sesiones siguientes enlazando con las sesiones desarrolladas en los días previos. Es importante que las niñas desarrollen vínculos sanos con los mayores que están a su alrededor, y muchas de las actividades para hacer en casa que encontrarás en esta guía se basan en preguntas y conversaciones que las niñas deberán tener con sus padres, madres, abuelos, amigas mayores, líderes y lideresas comunitarias. Es importante que el conocimiento se comparta entre distintas generaciones, que pase de las y los mayores hacia las niñas. 


\section{Las palabras que nos nombran}

También quisimos poner en tus manos una breve muestra de poemas y relatos escritos por algunos de los escritores más importantes de la historia en Guatemala. Estos breves fragmentos te ayudarán a conocer obras literarias de gran calidad, que siempre son útiles para pensar el lugar que habitamos y la sociedad de la que formamos parte. En cada sesión encontrarás un fragmento que puede llamar tu atención y que podrás complementar buscando en internet otras obras de las y los autores incluidos.

\section{Ruta hacia un proyecto comunitario}

Recuerda también que durante todo este proceso de 18 sesiones deberás desarrollar junto a las niñas un proyecto comunitario que refuerce los conocimientos que han adquirido y que sea útil para la comunidad de la que forman parte. La libertad para desarrollar este proyecto es absoluta, y las niñas y tú definirán todos sus componentes y sus formas. A lo largo de las sesiones te recordaremos que deben definir y ejecutar el proyecto comunitario, y te daremos algunos ejemplos y opciones que les pueden resultar útiles.

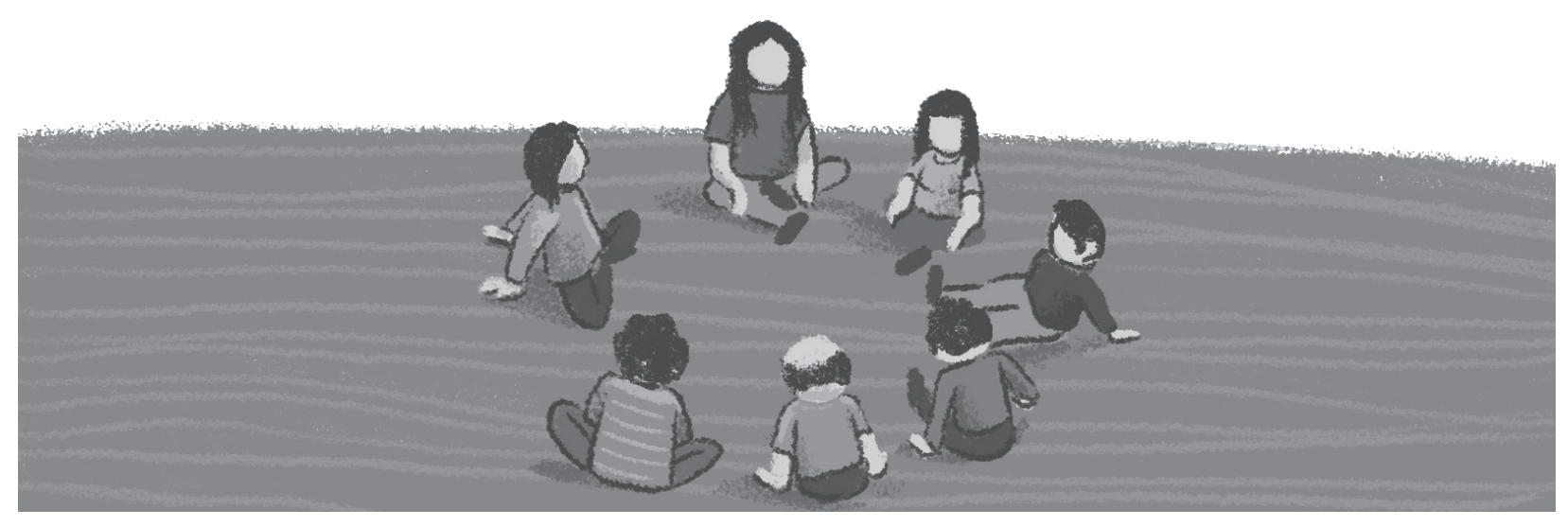

\section{Hagamos memoria}

Es importante que tú -como mentora-y las niñas vean cada una de estas 18 sesiones como parte de un proceso: cada vez que nos reunamos, iremos acumulando conocimientos, experiencias y sensaciones. Por eso, al iniciar cada sesión, recuerda con las niñas los contenidos de la sesión previa y pongan en común los resultados de las actividades que desarrollaron en casa.

Empecemos entonces, alegres y contentas, a recorrer la historia de nuestros territorios y nuestras comunidades de la mano de Esperanza. 


\section{Sesión 1}

\section{Las grandes preguntas de Esperanza}

Tu grupo de $\mathrm{AO}$ está a punto de iniciar un viaje muy profundo. Recorreremos nuestros territorios, pero también nos moveremos en el tiempo. Es maravilloso, ¿̇verdad? Estamos aquí y ahora, pero con la mente, la imaginación, el conocimiento y las ideas, podemos movernos y visitar el origen de nuestros pueblos, podemos pensar y sentir esa historia larga que no ha traído hasta acá.

Saluda a las niñas que se integran al grupo. Platica con ellas. Pregúntales por sus actividades diarias, por sus estudios y por sus familias. Mientras todas se reúnen, háblales con entusiasmo del extraordinario recorrido que empezarán hoy.

Cuando todas estén listas, busca un lugar cómodo donde puedan estar de pie, y ubícate ahí con ellas. Desarrolla la siguiente actividad.

\section{Nuestras grandes preguntas}

Lee el siguiente texto, o platícalo con las niñas en tus propios términos:

A veces hay preguntas tan grandes que nos envuelven, tan grandes que no caben en palabras. Son preguntas que parecen sencillas, pero que son muy profundas. $Y$ eso no quiere decir que no tengan respuesta: al contrario, las respuestas suelen estar tan dentro de nosotras mismas, que parecieran estar hechas de nuestra misma sustancia. ¿Cuáles pueden ser esas preguntas inmensas que casi nunca nos hacemos? Aquí hay algunas:

- ¿̇Quién soy?

- ¿ंPor qué estoy acá?

- ¿De dónde vengo?

- ¿2Por qué soy así?

- ¿Cómo es el lugar donde vivo?

- ¿̇Por qué son así las personas que veo todos los días?

Pídeles a todas que cierren un momento los ojos y que se relajen. Que traten de poner su mente en blanco. Luego pídeles que pongan una mano sobre su pecho y que traten de sentir los latidos de su corazón. Respiren profundo y pongan mucha atención a su palpitar. Cuando todas las niñas estén así, repite con voz tranquila todas estas preguntas: 
- ¿̇Quién soy?

- ¿Por qué estoy acá?

- ¿̇De dónde vengo?

- ¿Por qué soy así?

- ¿Cómo es el lugar donde vivo?

- ¿Por qué son así las personas que veo todos los días?

Dilas muy lentamente, una a una, y haz tres repeticiones.

Luego pídeles que abran los ojos.

Mientras las niñas tienen los ojos cerrados y están escuchando las preguntas, tú debes verlas con atención. Es importante que el silencio sea casi total y que tu voz sea lo único que ellas puedan escuchar. Con esto crearás un ambiente lo suficientemente alejado de cualquier sonido cotidiano, y las niñas comprenderán que están haciéndose preguntas realmente trascendentes.

Platiquen entre todas, teniendo en cuenta las siguientes preguntas:

- Cuando se preguntaban quién soy, por qué estoy acá, de dónde vengo y por qué soy así, ¿̇qué veían?: ¿̇u rostro? ¿̇Su nombre? ¿̇u casa? ¿̇Su familia? ¿̇Todo lo anterior? ¿̇Algo diferente? Discutan entre todas la experiencia que acaban de tener.

Pregúntales también si alguna vez se habían hecho ya estas preguntas. Deja que las niñas hablen contigo y entre sí.

Recibirás un audio que tendrá grabado el siguiente texto. Si tu teléfono tiene buen sonido, o si cuentas con alguna bocina, compárteles el audio. Si no, puedes leerlo tú misma:

Somos cuerpo, pero también somos ideas. Estamos hechas de muchas personas que existieron antes que nosotras: cientos, quizá miles de personas forman una cadena inmensa que nos puso hoy acá. Somos memoria, pero también somos imaginación. Somos lo que recordamos y lo que deseamos. Somos como nuestros padres y madres, como nuestros

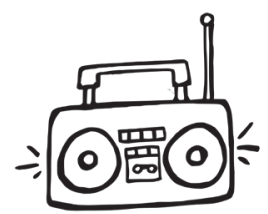
abuelos y abuelas, pero también somos diferentes a ellos. Somos personas individuales pero también somos la comunidad, que es como un cuerpo más grande que nuestro propio cuerpo. Somos las que caminan entre la naturaleza, pero también somos la naturaleza. Somos pensamiento, somos alegrías, somos sueños, somos tristezas, somos fuertes y a veces también somos débiles. Somos amigas, hermanas, tías, primas... Quizá en algún momento seamos madres, abuelas, ancianas... Somos las que cruzan un río, pero también somos el río. Somos las que suben un cerro pero también somos el cerro. Somos las que miran las estrellas pero

$$
\text { Giva para mentoras de Abriendo } O_{\text {portunidades }}{ }^{\circledR}
$$


también somos las estrellas. Aunque no las veamos, tenemos raíces como las de los árboles, tenemos retoños como los de las flores. A veces esos retoños y esas raíces son una idea, a veces son las voces del pasado que nos llegan. Somos nuestro nombre, nuestra voz, nuestra fuerza.

\section{Los relatos de Esperanza}

Cuéntales a las niñas que en cada sesión compartirás con ellas un cuento que tiene como personaje principal a Esperanza, una niña que se parece mucho a ellas. Cada semana, iremos conociéndola más, con sus pensamientos, sus emociones y sus preguntas. También conoceremos a sus amigos y sus familiares, y ella nos guiará por la historia del territorio y la comunidad que compartimos.

Recibirás cada uno de estos cuentos en un audio, que podrás compartirles directamente o bien leerlo tú misma:

\section{La abuela montaña}

Una tarde, mientras camina sola y pensativa, Esperanza quiere esconderse un momento porque se siente triste. Recién acaban de talar muchos árboles cerca de su comunidad y siente que tiene que llorarlos -como si fueran personas- porque estaban vivos. En su caminata encuentra un paredón. Ese paredón es el resultado de una máquina que se comió un pedazo de cerro, quizá hace ya mucho tiempo. Esperanza se acerca, mira y toca con atención la tierra y las rocas que forman la montaña. Distingue varias franjas y cada una es distinta: en algunas hay piedras grandes, otras son húmedas, otras son casi blancas. Esperanza está deslumbrada y siente el impulso de preguntarle a la tierra misma por qué existen esas diferencias. Así, pone su mano sobre la tierra, cierra los ojos y escucha la voz de una anciana que le cuenta la siguiente historia:

-El mar, querida Esperanza, es un inmenso cuerpo de agua que nunca se está quieto. A él le nació la vida. De su profundidad se levantó un día la tierra que quería tocar el aire y desde entonces los continentes han buscado su lugar, mientras les nace también a ellos la vida. La última vez que el mar dio a luz un pedazo de tierra fue una delgada línea que estaba destinada a unir, a ser puente, pero también casa.

"Esa delgada línea se llama hoy Centroamérica, y diríamos que es tan joven que aún su tierra tiene la humedad del mar, y aunque para nosotros han pasado millones de años, para el mar es todavía una tierra recién nacida.

"Su forma parece una pequeña muestra del mundo: las más altas cimas conviven con las playas, los climas más fríos y los más cálidos están uno a la par del otro. Bosques, planicies, volcanes, valles... Todo en una tierra que desde el espacio exterior se ve muy pequeña, pero que para nosotras es inmensa, y ha sido el hogar de civilizaciones, de gente que piensa y siente, de las más variadas formas de vida y de hermosas geografías.

8 Esperanza y la gran historia de nuestro camino 
Esperanza estaba muda, escuchando con atención lo que le decía la Abuela Montaña.

-Son millones de años, mi querida Esperanza -le decía la voz de la anciana-, y en millones de años la historia no puede ser solo una. Son muchísimas historias en muchísimo tiempo, por eso es necesario dividir ese tiempo, ponerle nombres y contar por partes para que puedas comprender la gran historia de nuestro camino.

"Debes tener presente que el lugar en donde vives es parte de un lugar más grande. Tu comunidad es parte de un municipio, el municipio de un departamento, el departamento de un país, el país de una región y las regiones están todas sobre una porción de tierra muy grande que es un continente. El nuestro se llama América, y ocupa una gran parte de nuestro planeta la Tierra.

"Pero no siempre hubo gente en América, Esperanza, la humanidad como tal inició en África, otro continente que está muy lejos de aquí. Pero ustedes, los seres humanos, siempre han buscado, han explorado, han querido ver con sus propios ojos el planeta en que viven. Son como el mar, que nunca se está quieto. Por eso, desde África las personas empezaron a caminar y a ocupar poco a poco los continentes. Pasaron los años, los siglos, y sus cuerpos fueron tomando distintas formas para adaptarse a las condiciones de la tierra a la que llegaban, cambiando de color de piel, de tipo de pelo...

- ¿Cómo llegó la gente a América -preguntó tímidamente Esperanza.

-Justo eso es lo que quiero contarte. La gente llegó a América caminando a través de un puente de hielo que se formó entre Siberia (Asia) y lo que hoy conocemos como Alaska (América). Ese puente se llama Estrecho de Bering, y unió los dos continentes durante algunos miles de años, tiempo suficiente para que las personas, los animales y otras formas de vida avanzaran del norte al sur de América.

Abuela Montaña hizo una pausa, como tratando de recordar, hasta que su voz sonó de nuevo en los oídos de Esperanza:

-Las culturas que han vivido y viven en América son muchísimas, pero el lugar en donde se han desenrollado nuestras historias se llama Mesoamérica, que es la parte media del continente en que las culturas hermanas se han desarrollado, y son culturas hermanas porque lo que comen se parece, porque cuentan el tiempo de formas similares y porque comparten formas de construcción y de escritura. Las culturas mesoamericanas ocupan el territorio que va del centro al sur de México, Guatemala, Belice, El Salvador y la parte occidental de Honduras.

"La cultura Maya es una de las más importantes de Mesoamérica. Abarca un territorio muy grande y al menos unos cuatro mil años. ilmagínate: cuatro mil años! Para comprenderlo mejor, hoy se conoce como periodo Preclásico a los años en que se formó la cultura de la que eres parte, mi querida Esperanza. La gente se asentó en lugares permanentes, empezó a sembrar su milpa, a cuidar sus cultivos y criar animales. Sabemos eso porque dejaron muchísimos rastros de su paso por la tierra: hicieron vasijas de distinta forma, construyeron sus casas, sus herramientas, sus obras de arte. Empezaron a contar el tiempo y a crear historias, relatos que hoy pocos conocen. Sin embargo, su pensamiento vive. Las primeras formas viven, y tú lo sabes.

"Luego vino el periodo Clásico. Así se llama ahora al momento que vino después. Seiscientos años de apogeo arquitectónico y de la cuenta del tiempo. En esos días se construyeron majestuosas ciudades, que aún hoy sorprenden a quien las mira. El arte

$$
\text { Giva para mentoras de Abriendo } O_{\text {portunidades }}{ }^{\circledR}
$$


estaba por todos lados, y también los dioses y los gobernantes. Aún hoy, mil quinientos años después, se conservan sus imágenes, sus caras y sus nombres.

"Y luego, durante el periodo Posclásico, muchas de las grandes ciudades se abandonaron, pero se construyeron otras igual de grandes, igual de complejas. La gente comerciaba con muchos pueblos, los bienes y las ideas andaban por todo el territorio. En ese periodo se reorganizó la vida y entonces, de pronto, las cosas cambiaron. Pero de eso hablaremos después.

"Lo que debes recordar, Esperanza, es que la civilización Maya está viva, cambia, se adapta, crece, se reorganiza. ¿̇Por qué digo que está viva? Porque tú ves el mundo de la forma en que la civilización de la que eres parte te enseñó a hacerlo, y el hecho de que tú estés acá, hablando el idioma que hablas, sembrando, tejiendo, contando los días, es la muestra clara de que esa civilización que te cuento no ha muerto nunca.

Esperanza abrió los ojos. Seguía escuchando la voz de la Abuela Montaña aunque ya no entendía sus palabras. Con lágrimas en sus ojos, le dio las gracias a la Tierra por haberle contado una historia de la que ella formaba parte.

Platiquen sobre el cuento que acaban de escuchar. ¿Qué llamó más su atención? Es importante que las niñas tengan claros dos elementos:

1. El territorio que hoy conforma buena parte de Guatemala surgió del fondo del mar hace millones de años. El choque de las placas tectónicas del planeta fue levantando los suelos y formando la geografía que podemos ver hoy: montañas, volcanes, valles y costas. Centroamérica entera tiene una función muy importante para el surgimiento de la vida en la Tierra: unió los dos grandes bloques del continente americano, separó los océanos e hizo que el clima en el planeta fuera como es hoy. Todo ese proceso maravilloso ha durado una enorme cantidad de tiempo.

2. El continente americano fue poblado gracias a una migración que también duró muchísimo tiempo. Los primeros grupos humanos que llegaron al territorio actual de Guatemala lo hicieron hace unos 15 mil años. Aprovecharon las características del suelo y el acceso a recursos básicos -fuentes de agua y de alimento, así como lugares en los que pudieran protegerse- para asentar sus comunidades. En en los departamentos de Huehuetenango, Quiché y Guatemala se han encontrado algunos objetos que los primeros pobladores de los territorios hicieron como parte de su vida diaria.

\section{Hagamos algo juntas}

Para que hoy día podamos habitarlo, el paisaje ha tenido una historia muy larga, muy compleja y muy hermosa. No son pocas las fuerzas que han intervenido para que se formaran las montañas, ríos, volcanes y costas que hoy podemos ver. Habla 
de eso con las niñas, y ubica en los alrededores del lugar donde se desarrolla la sesión un espacio al aire libre donde puedan tener contacto con tierra, piedras, plantas y diversos materiales de la naturaleza.

Organiza dos grupos, y pídeles a las niñas que hagan la representación de un paisaje que les resulte familiar (que tenga montañas, sitios planos, alguna fuente de agua, etc). Para ello usarán todos los elementos que estén disponibles en el entorno. Mientras ellas buscan tierra, la mueven y van formando su paisaje, tú puedes hablar con ambos grupos para hacerles ver el tiempo y la fuerza que se necesita para formar esa representación. Que imaginen cuánto tiempo y cuánta fuerza se necesitaría para formar el paisaje actual de la comunidad.

Cuando los dos grupos terminen, pídeles que describan su paisaje al otro grupo y platiquen juntas sobre su experiencia "creando montañas".

\section{Las palabras que nos nombran}

Reúne a las niñas en el espacio habitual, pues la primera sesión está a punto de terminar. Antes de que se vayan, compartirás con ellas este fragmento de un poema del escritor Luis Alfredo Arango, que nació en Totonicapán en 1935. Pídeles que lo escuchen con atención y que traten de imaginar lo que indican las palabras del poema:

\section{Poema del tiempo circular (fragmento) Luis Alfredo Arango}

Estoy de paso aquí pero también estuve con los jefes andariegos y descalzos, con los fundadores, los que vieron esta tierra antes que nadie, se acercaron a sus lagos con asombro, con el alma dilatada de emoción y lo primero que hicieron fue arrodillarse, lavarse las pestañas y la frente, mojarse el pecho desnudo, asperjar como en un sueño a sus mujeres $y$ a sus hijos y bautizarlo todo con nombres que sacaban de las peñas, 
de las canteras, del jugo de los árboles, de zumos y raíces virginales.

Estuve.

Fui con ellos a gozar, a contemplar los valles, las montañas azulencas, sumergidas todavía en la neblina primordial.

Ellos todo lo tomaron de la tierra, supieron preguntarle, interrogar al barro, a los volcanes, a los ríos...

Esa fue su Gran Sabiduría:

vestirse con las flores que hallaban a su paso, ponerse plumas y collares de semillas, lucir pieles doradas, trabajar con alegría, regalarse con los frutos de la tierra, levantarse, edificar ciudades, inventarse dioses nuevos...

Al terminar, pregúntales qué les pareció. Imaginen juntas cómo habrán sido los primeros habitantes de las tierras en que ahora ustedes viven. ¿̇Qué le preguntarían a las personas que fundaron su comunidad?

\section{Oportunidades en casa}

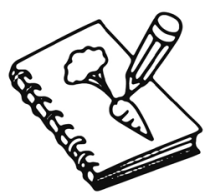

Dile a las niñas que en cuanto lleguen a su casa platiquen con sus familiares sobre todo lo que hicieron, escucharon y pensaron en la sesión de hoy. En una hoja en blanco que les entregarás, diles que hagan lo siguiente:

1. Dibujen un pequeño mapa de su comunidad.

2. Identifiquen las fuentes de agua y de recursos disponibles.

3. Identifiquen si hay algún lugar que consideren sagrado.

4. Incluyan en el dibujo algún elemento que permita definir el clima en la comunidad.

5. Discutan el mapa y complétenlo en familia.

6. En la parte de atrás, respondan -con ayuda de sus familiares- las siguientes preguntas: ¿Por qué se asentó aquí la comunidad?

¿Qué ventajas tiene nuestro entorno inmediato?

¿Cuándo se fundó la comunidad en la que vivimos? 
Al iniciar la siguiente sesión, las niñas te entregarán la hoja con su dibujo y sus respuestas. Compartan algo sobre la experiencia que cada una tuvo en su casa.

\section{Ruta hacia un proyecto comunitario}

Recuerda que un elemento importante de todo este proceso es el proyecto comunitario. Al finalizar la primera sesión y cuando las niñas se hayan ido a casa, piensa e imagina qué tipo de proyecto te gustaría realizar. Durante las siguientes sesiones, las niñas irán conociendo más a fondo la historia de Guatemala, desde los tiempos más remotos -en que surgió el territorio y empezó a poblarse- hasta hoy. Como mentora y responsable del grupo, responde las siguientes preguntas:

- ¿Qué tipo de proyecto me gustaría hacer?

- ¿QQué necesito para llevarlo a cabo?

- ¿Cuánto tiempo podemos dedicar a nuestro proyecto comunitario?

- ¿Qué apoyos debo solicitar para poder realizar el proyecto?

En las próximas sesiones iremos aterrizando las ideas necesarias.

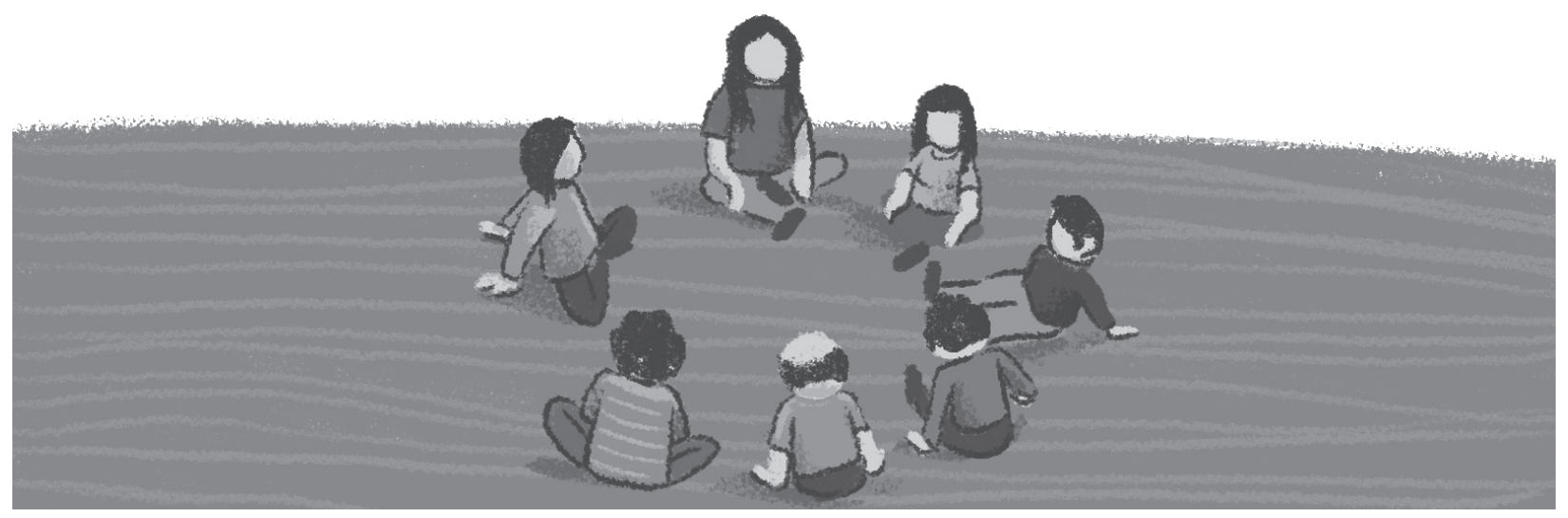




\section{Sesión 2}

\section{Nuestra cultura madre}

En esta segunda sesión de nuestro grupo veremos contenidos sumamente importantes, que tienen que ver con el alma de nuestra cultura. Hablaremos de personas que estuvieron aquí hace muchísimos años, y que crearon dinámicas que aún hoy son muy importantes para nuestra vida diaria.

Mientras las niñas van llegando y se suman al grupo, platica con ellas. Pregúntales por su vida diaria (especialmente sobre la escuela) y cuéntales detalles de la tuya.

\section{Hagamos memoria}

Para empezar, pídele a las niñas que te ayuden a recordar los contenidos de la sesión anterior. $\dot{2}$ Recuerdan el cuento que escucharon, las actividades que hicieron? íRecuerdan a Esperanza?

Durante la semana, cada participante debía llenar una pequeña hoja de trabajo, que incluía un dibujo de su comunidad y la respuesta a las siguientes preguntas:

- ¿̇Por qué se asentó aquí la comunidad?

- ¿Cuándo se fundó la comunidad en la que vivimos?

Pídeles que voluntariamente compartan sus dibujos con las demás, y que nos cuenten la experiencia familiar que tuvieron al realizarlos. Luego, platiquen sobre las respuestas que obtuvieron a las tres preguntas y encuentren los puntos en común. Experimenten juntas cómo se complementan los aportes de cada una.

\section{Hagamos algo juntas}

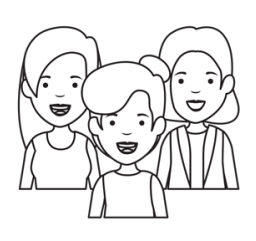

Organiza a las niñas en cuatro grupos y diles que cada grupo será el encargado de formar una comunidad. A partir de lo que platicaron hace unos momentos, invítalas a imaginar un lugar para vivir bien. Tú le darás a cada grupo una característica clave, y ellas imaginarán todas las demás. Puedes usar estas, o algunas más que tú imagines:

Ustedes estarán a la orilla de un río.

Ustedes se ubicarán en el centro de un valle.

Ustedes estarán en el cerro. 
Ustedes se asentarán entre árboles.

Etc.

Cada grupo deberá reunirse y hacer una lista de las características que un terreno debería tener para empezar su nueva comunidad, de acuerdo a la característica esencial que tú les asignaste. Pídeles que definan juntas cómo serían las casas y las calles de la comunidad, qué servicios necesitaría para ser bonita y funcional. En base a eso, cada grupo deberá escoger el nombre que le darían a su comunidad. Cuando definan esos detalles, comparen la comunidad que quisieran fundar con la comunidad en la que viven ahora. ¿Son totalmente distintas? ¿Se parecen?

Al concluir, reúnanse nuevamente y pide a cada grupo que le muestre a las demás su comunidad, utilizando los recursos que quieran y que tengan a su alcance: dibujos, muebles que estén cerca, etc. Llévalas, con la imaginación, a ese lugar que ellas fundaron.

\section{Las palabras que nos nombran}

Humberto $\mathrm{Ak}^{\prime}$ abal es uno de los poetas más reconocidos de Guatemala y era del pueblo k'iche'. Murió en 2019 y escribió muchos libros que han recorrido el mundo. Comparte con las niñas este breve poema y, al finalizar, discútanlo entre todas. Traten de responder qué sienten al escucharlo, qué ideas les trae a la mente:

\section{Camino al revés \\ Humberto $\mathrm{Ak}^{\prime}$ abal}

De vez en cuando

camino al revés:

es mi modo de recordar.

Si caminara sólo hacia delante,

te podría contar

cómo es el olvido.

\section{Los relatos de Esperanza}

Comparte la siguiente historia con todas las niñas:

\section{El almanaque del abuelo Lix}

Una tarde, Esperanza estaba en su casa escogiendo el maíz que más tarde pondría a cocer. Su abuelo -que es zapatero- trabajaba en una esquina de la habitación. La luz que iluminaba a su abuelo también

$$
\text { Guia para mentoras de Abriendo Oportunidades }{ }^{(3)}
$$


iluminaba un almanaque que estaba colgado en la pared y al que Esperanza no le había puesto atención. Recién había empezado el año y no se había acercado a ver la foto. Se acercó y vio la fotografía de un edificio de piedra. Era muy grande, se veía antiguo, era de forma triangular y tenía gradas en el frente. Eran muchas -porque el edificio era muy alto- y llevaban hasta la cima, en la que había una sola puerta. Ese edificio parece una montaña, pero fue hecho por personas -pensó Esperanza. Al fondo de la foto se veía una selva que parecía no tener final, y que de tan verde se iba haciendo azul. Abajo, en la descripción de la imagen se leía: "Gran Jaguar, Tikal".

-Tata Lix -le dijo Esperanza a su abuelo-, ¿̇qué lugar es ese que aparece en la foto del almanaque?

Su abuelo la vio con ternura, y se sonrió mientras terminaba de clavar un pequeño clavo en el zapato que trabajaba.

-Se llama Tikal, mija, y Tikal era una de nuestras ciudades. Porque aquí hubo unas ciudades enormes, lindas, con edificios que parecías soñados, que incluso viéndolos se preguntaba uno 'żpero cómo hicieron estas bellezas?', ciudades que parecían paisajes...

-¿̇Entonces ya no existen? -preguntó Esperanza.

-Claro que existen, mija. Existen, pero ha pasado mucho tiempo, han pasado muchas cosas, han cambiados las vidas, pero esas siguen siendo nuestras ciudades. Esas ciudades son mayas como nosotros, como nuestro idioma, como nuestra comida, mija. Nada de eso se ha muerto, pero las cosas que han pasado, y el tiempo, que ha sido tanto, a veces como que nos borra el camino de la memoria.

Al día siguiente, Esperanza fue muy contenta a la escuela y le contó a su maestra la plática que había tenido con su Tata Lix sobre Tikal. La maestra no le puso mucha atención, y le dijo que eso no era cierto, pues los mayas habían desaparecido hace mucho. Esa misma tarde, al regresar a su casa, Esperanza le mencionó lo sucedido a su abuelo, quien levantó la vista y con los ojos un poco húmedos -pero con una sonrisa grande- le dijo:

-No, mija, cómo se iban a desaparecer: si somos nosotros, si hablamos nuestro idioma, si comemos lo mismo que comían las gentes antiguas. ¿Sabés qué? Hoy es un día bueno, el día Kan, que nos ayuda a escuchar a las personas de otra época. Venite conmigo, vamos a ir a hablar con el fuego. Él te va a quitar las dudas.

Empezaron a caminar, y en lugar no muy lejos de su casa estaba la entrada de una pequeña cueva, a la par de un cerro chiquito. Desde ahí se veía muy claramente el patio de la casa de Esperanza: su ropa colgada, su maíz secándose en el techo, los pollos que corrían, su huerto que no dejaba de crecer.

Su abuelo puso en un lugar preciso cuatro candelas: una negra, una amarilla, una roja y una blanca. Dibujó un cuadro, abrió las tusas que envolvían su pom y su copal, sacó las candelas chiquitas de los mismo colores, dibujó un círculo con azúcar, puso unas flores y al centro puso otras dos candelas: una verde y una azul. Esperanza lo había visto hacer eso varias veces, tenía en su memoria el fuego y el olor de las ofrendas quemándose, pero ese día era especial, porque ella también iba a hablar con el fuego.

Hablando al cielo, a su Corazón del Cielo; hablando a la tierra, a su Corazón de la Tierra; viendo en las cuatro direcciones que marcaban las candelas, el fuego empezó a

16 Esperanza y la gran historia de nuestro camino 
crecer. Su abuelo iba contando los días, iba ofreciendo candelitas para que comiera el fuego. Esperanza vio cómo el fuego de pronto creció, se hizo como una trenza, se estiró, y lo empezó a escuchar, no con los oídos, sino con su corazón. Vio formas en el fuego, las vio no solo con sus ojos, también con su corazón y sus pensamientos. Y así, con voz de viento y fuego, con figuras hechas de llamas empezó el fuego a contarle a Esperanza el largo camino de su historia:

Esperanza, esta tierra en la que tienes tus pies, estos cerros que miras alrededor, estos ríos, estos caminos, han estado acá hace muchísimo. Ahora le dicen Guatemala a la tierra, le dicen Alta Verapaz, Chisec, Chiquibul, Yalcoc, Secomocoh... pero hubo otros tiempos en los que esta tierra no se llamaba así.

Antes no había gente, pero hará unos 14 mil años que empezó la gente a andar sobre estas tierras. Fueron buscando los mejores lugares para pescar, para cazar, para cortar su comida de los árboles. Iban hablando con la naturaleza, pensando y observando; entonces, se dieron cuenta de que podían sembrar sus semillas y hacer crecer más comida. Cuando vieron crecer las plantas que les darían de comer se fueron quedando quietos, ya no andaban buscando en dónde había más, porque habían aprendido a sembrar. Entonces se pusieron a construir sus casas, a cuidar la tierra que les hablaba.

Al principio, los lugares cerca del mar eran los mejores, pero la curiosidad siempre ha movido a la gente y muchos se fueron siguiendo al agua, dejaron que los ríos les enseñaran más caminos, les enseñaran otras tierras, otros frutos, otros animales. Y así se fueron moviendo por todo tipo de tierras, adaptando su forma de sembrar, de hacer sus casas. Casi toda la vida era al aire libre, su techo era el cielo, y las viviendas que construían se usaban solo para dormir y para cocinar.

Hicieron edificios altos, muy altos, para subir a ellos y hablar con el cielo. Veían con dedicación el movimiento del sol y las estrellas, hablaban con el universo, aprendieron a preguntarle cosas. En las fachadas de sus edificios hicieron formas, que tal vez el cielo les mandaba cuando estaban dormidos, cuando soñaban. Así pasaron miles de años, poblando esta tierra que hoy se llama Guatemala, formando la cultura que es nuestra madre.

Se fue llenando todo el territorio de aldeas y comunidades, también fueron haciendo sus construcciones más formales, más grandes, y empezaron a construirse las primeras ciudades, los primeros edificios que servían para la organización de toda la gente que vivía en esas ciudades y los que servían para hablar con el cielo, con el fuego, con las estrellas, como tú misma lo haces ahora. Así, las formas de lo que hacían las gentes antiguas se convertían en pintura, en arquitectura, en escultura. Hubo gentes que aprendieron el lenguaje de los números, que se hicieron científicas, sacerdotes, escritoras.

Ahora le llaman "La Danta" al edificio más grande que se ha construido no solo en esta tierra sino en el mundo, y se hizo en esos años en los que la cultura fue floreciendo, mientras se poblaban ciudades cerca del mar -como La Blanca-, o ciudades que quedaron debajo de ciudades más nuevas -como Kaminaljuyú. Luego vino la época que le llaman Clásica. Ahí las ciudades se fueron haciendo más complejas, su orden social se hizo más estricto, había comercio con ciudades que ahora son de México, El Salvador, Honduras y Belice, pero que antes no eran países, eran Quiriguá, Copán, Nebaj, Uaxactún, Machaquilá, Calakmul, Tikal, Aguateca... ciudades imponentes, hechas de piedras e ideas. Sus reyes

$$
\text { Guia para mentoras de Abriendo Oportunidades }{ }^{(3)}
$$


quedaron inmortalizados en piedra, sobre piedra también se escribieron los hechos más importantes, las fechas grandes, las guerras ganadas, las guerras perdidas, las formas de hablar con los dioses. La gente empezó a sacar jade de la tierra, y desde entonces es importante la preciosa piedra que es verde o rosada o lila, y empezaron a venderlo, a hacer adornos para colgarse en el cuerpo.

Esto te lo cuento aquí, y lo que escuchas lo aprendí de las voces del tiempo que vienen cuando las llamas. Pero también puedes ir tú misma a ver la historia sobre las piedras, puedes ir a un lugar que se llama Cancuén o B’omb'il Pek, y que no está tan lejos. Ahí hablarán contigo los edificios, los reyes tallados, los números y las historias de las gentes antiguas, que son los abuelos y las abuelas de toda la gente que vino después. Y si quieres saber cómo eran sus caras, mírate en un espejo, Esperanza, mira a tu familia y a tus amigas. Las gentes antiguas están lejos en el tiempo, pero tienen la misma madre que tú: la cultura en la que naciste.

Cuando el sol se fue escondiendo en el horizonte y el azul del cielo se puso intenso y oscuro, Esperanza vio a través del fuego las primeras estrellas. El fuego se quedó dormido, y su abuelo seguía diciendo la lista inmensa de los días. Caminaron juntos de regreso a casa, y al entrar, todavía con el sonido del fuego en sus oídos, con la historia contada en llamas aún guardada en sus ojos, Esperanza se acercó a la foto del almanaque, esa que decía "Gran Jaguar, Tikal", y sintió que ya lo conocía. Se le hizo tan familiar, y sintió que era algo así como una casa.

Luego de escuchar este cuento con atención, coméntenlo en grupo.

\section{Nuestras grandes preguntas}

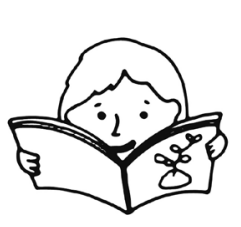

Es el año 2021, y nosotras habitamos hoy nuestras aldeas, nuestras comunidades y nuestros municipios. Pero estos territorios han sido ocupados por gente como nosotras durante miles de años.

Nuestro camino ha sido largo, hemos pasado por muchas cosas buenas y malas, y seguimos aquí.

Lanza la siguiente pregunta a todas las niñas, y vayan construyendo juntas una lista con las respuestas:

- ¿Cuál es nuestra cultura madre?

- ¿QQué elementos de nuestra vida diaria vienen de nuestra cultura madre?

Ayúdalas a pensar en elementos que tengan que ver con la comida, las formas de siembra, el idioma que hablan, su ropa, sus tejidos, las cosas que hay en su casa. Recuérdales que la cultura maya, que empezó a desarrollarse hace más de 3,500 años, es la raíz de donde venimos. 


\section{Oportunidades en casa}

Hablar de miles o de cientos de años es difícil. Son cantidades de tiempo

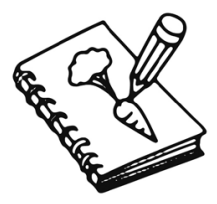
que nos cuesta trabajo imaginar. Sin embargo, es importante que tú y las niñas sepan que la cultura que las contiene es sumamente antigua y que tiene una gran vitalidad. No todas las culturas son capaces de adaptarse y sobrevivir durante tanto tiempo. Por eso, es importante reconocer la fuerza de la que formamos parte, una fuerza que atraviesa el tiempo.

Dile a las niñas que pongan atención a esta pequeña actividad que deberán realizar en casa. Recomiéndales que la empiecen a trabajar en cuanto lleguen, para que no se les olvide y puedan traer los resultados a la próxima sesión.

1. Cada una deberá escoger un corte. Puede ser suyo o de sus mamás, pero usarán el que más les guste, el más colorido, el más bonito. En cuanto lo hayan escogido, deberán observarlo con atención, y luego harán una lista de todos los colores que tiene.

2. Cuando hayan completado la lista, piensen en lo que significa para ustedes cada color: qué sentimiento les transmite, qué les hace recordar. Anoten ese significado.

3. Si tienen crayones a la mano, pueden acompañar el listado de colores con un dibujo sencillo de las formas que incluye el corte. Así, lo podrán compartir con sus compañeras durante la próxima sesión.

El objetivo de esta actividad es que las niñas comprendan que los trajes que usan no son solo prendas de vestir, sino que en ellos hay mucho conocimiento, creatividad, ideas y emociones. Además, cada uno es una pieza de gran belleza.

\section{Ruta hacia un proyecto comunitario}

Antes de concluir la sesión, cuéntale a las niñas que durante las siguientes semanas harán juntas un proyecto de beneficio para su comunidad. Pídeles ideas, cuéntales las respuestas que tú ya tienes claras desde la semana pasada. Los aportes de todas permitirán que sientan este proyecto como algo propio. En un papelógrafo o en un cuaderno, puedes ir anotando todas las ideas que surjan, pues las deberán discutir más adelante, al decidir qué tipo de proyecto harán.

Recuerda que producir juntas un objeto -algo que se pueda ver y tocar- que reúna y materialice los conocimientos, ya que al verlo ustedes y los miembros de la comunidad podrán recordar la historia que hay detrás de él.

Aquí te proponemos tres opciones que podría ser interesante discutir con las niñas:

1. Un mural (que cuente la historia de la comunidad a la que pertenecen).

$$
\text { Guia para mentoras de Abriendo Oportunidades }{ }^{(3)}
$$


2. Un libro ilustrado (que reúna conocimientos de todas las participantes que sean útiles para la comunidad).

3. Una excursión juntas a algún sitio arqueológico cercano (por ejemplo, al sitio Cancuen, ubicado en el sur de Sayaxché, Petén o B'omb'il Pek, ubicado en Chisec).

Cualquiera que sea el proyecto que eligan, piensa siempre en las necesidades y en las posibilidades de la comunidad.

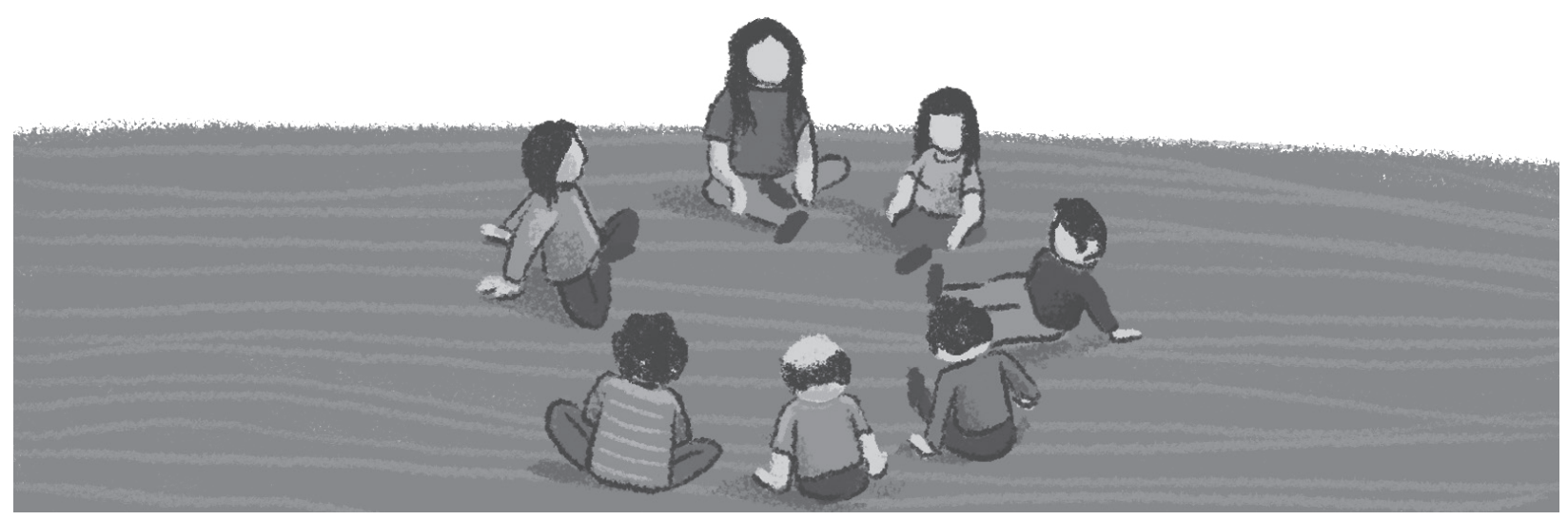




\section{Sesión 3}

\section{Las ramas de un mismo árbol}

Esta será nuestra tercera sesión aprendiendo juntas con Esperanza sobre los orígenes más lejanos de nuestra cultura y nuestra comunidad. Como recordarás, la Montaña y el Fuego le han contado a esta niña cosas que no escuchamos con frecuencia en nuestro entorno, cosas sobre el origen del territorio que habitamos y sobre los pueblos que han vivido sobre él durante miles de años.

Mientras se reúnen, platica con las niñas. Pregúntales por sus familiares, por cómo les va en la ecuela y por su día a día. Interésate por ellas y por lo que tienen que decir. Aprovecha para reforzar todos estos conocimientos durante la plática.

En esta ocasión, aprenderemos que existe una época llamada "periodo Posclásico", en la que sociedades muy antiguas evolucionaron hacia los pueblos originarios que están vivos en la actualidad. Veremos que existen muchos pueblos, pero que tienen un origen y una historia antigua en común.

\section{Hagamos memoria}

Luego de que todas las participantes del grupo se reúnan, salúdalas y lánzales la siguiente pregunta:

- ¿̇Recuerdan qué le pasó a Esperanza en el relato de la semana pasada?

- ¿ ¿Con quiénes platicó?

Platiquen todas juntas al respecto.

\section{Nuestras grandes preguntas}

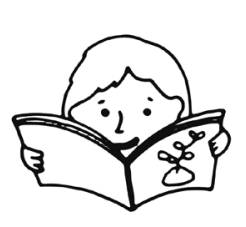

Muchas veces nos enseñan cosas que no encajan con la realidad que vemos y vivimos todos los días, cosas que contradicen las verdades que podemos percibir con la experiencia. ¿̇Recuerdas, por ejemplo, lo que le dijo su maestra a Esperanza en la sesión anterior? Así es: que los mayas habían desaparecido.

Platica con las niñas sobre esto. Pregúntales si han pasado por una situación similar. Y reflexionen juntas tratando de responder a la siguiente pregunta:

$$
\text { Giva para mentoras de Abriendo } O_{\text {portunidades }}{ }^{\circledR}
$$


- ¿̇A qué se debe que la educación oficial nos enseñe algunas cosas que contradicen la realidad?

\section{Las palabras que nos nombran}

Compartiremos ahora una pequeña parte de un libro que se llama Después del tango vienen los moros. Lo escribió el amigo escritor que conocimos en la primera sesión: Luis Alfredo Arango. Escúchenlo con atención:

\section{Después del tango vienen los moros (fragmento) Luis Alfredo Arango}

Hay muchas Guatemalas pero solamente una es verdadera: la que ya existía cuando quién sabe qué pueblos, en la costa sur, tallaron aquellas cabezas colosales de niños dormidos en piedras volcánicas. No se llamaba Guatemala, pero ya existía cuando nació Kaminaljuyú; ya vivía cuando los reyes de Tikal y Uaxactún se cayeron de sus tronos. Ella es la verdadera, la inmortal. La que nadie sabe cómo vive, de qué se alimenta, cómo ha hecho para no extinguirse.

La han masacrado. La han hecho polvo. La han molido y sigue viviendo.

¿Qué les pareció? Hazle notar a las niñas que el texto hace referencia a un hilo que hemos ido descubriendo entre la gente que vive hoy en nuestras comunidades y la gente que ha vivido antes en los mismos territorios. No importa que sean cientos o miles de años: hay algo que nos une.

\section{Los relatos de Esperanza}

Comparte con las niñas este relato de lo que le pasó una tarde a Esperanza:

\section{Las ramas de un mismo árbol}

Al día siguiente de hablar con el fuego, Esperanza fue a la escuela muy emocionada. Veía los cerros y pensaba cómo eran los lugares antes,

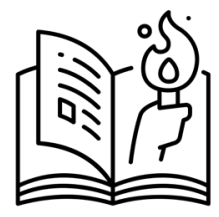
muchos años antes. Estaba maravillada de saber lo inmensas que eran sus raíces. Tenía ganas de contárselo a todas sus amigas y de preguntarle muchas cosas a su maestra. Pero su maestra le dijo nuevamente que no, que recordara que los mayas sí existieron pero que desaparecieron hace mucho, y que mejor pusiera atención porque hoy iban a aprender los símbolos patrios de Guatemala. 
Confundida y un poco triste, Esperanza tomó su lugar en clase. Entre los símbolos que aprenderían esa mañana se encontraba un árbol llamado Ceiba, el árbol nacional. La maestra les dijo que esta aparecía en las monedas de cinco centavos, e hizo un dibujo que cubrió todo el pizarrón.

En su camino de regreso a casa, Esperanza iba jugando con la pequeñísima moneda que muestra al árbol nacional. "Es tan chiquito", pensaba Esperanza. Guardó la moneda en su bolsa y siguió por el camino. De pronto, levantó la vista y su sorpresa fue grande, igual de grande que el árbol que estaba frente a ella:

-Es una ceiba -dijo emocionada. No le quedaban dudas: era exactamente igual a la que aparecía en la moneda, pero era grandísima. -Es más que una casa, más alta y frondosa que otros árboles.

Sin dudar, Esperanza corrió hasta su tronco, que era tan ancho que no le alcanzan los brazos para rodearlo. Necesitaría a muchas de sus amigas para rodearlo por completo. El sol se colaba por las ramas, pero eran tantas hojas que realmente solo lograban entrar unos pocos rayos. Esperanza estaba maravillada: escuchaba el canto de los pájaros que viven en ella, veía sus hojas moverse, pensaba que el árbol inmenso parece un pueblo entero, un país; parece un país de pájaros. Y la ceiba parecía estar feliz, parecía que le abría sus ramas para abrazarla.

En el tronco, Esperanza vio unos ojos: eran de la misma madera, pero los ojos empezaron a abrirse y a cerrarse. "No puede ser", pensó Esperanza, "la ceiba me está mirando". Pero no solo la veía: la invitó a sentarse en sus ramas y a escuchar su voz.

Ya el fuego y la Abuela Montaña te han contado cosas, criatura llamada Esperanza, pero las historias de nuestro camino son muchas y debemos conocerlas, porque no es cierto que la gente se desaparezca, no es cierto que una cultura solo se acabe; más bien, se adapta, se transforma. Mis ramas y mis raíces saben del tiempo, los pájaros que viven en mí saben historias, saben nombres; por eso te llamé, por eso quise que te sentaras bajo mi sombra.

Por eso ahora quiero contarte de esa cultura, tu cultura, la que construyó grandísimas ciudades, hizo rutas de comercio, dio al mundo conocimientos astronómicos, arte, historias, y que también tuvo problemas, como todas las culturas. Los abuelos de tus abuelos tuvieron que migrar cada cierto tiempo, hubo algunas guerras y hubo hambre. El agua estuvo escasa en esos años y la gente tuvo que buscar nuevamente ríos y lagos para que la vida siguiera siendo posible. Por eso algunas ciudades fueron abandonadas, pero eso no quiere decir que la gente desapareciera. Lo que pasó fue que se organizaron sociedades más pequeñas.

Su forma de hablar con nosotras -las energías, las plantas, la tierra- fue cambiando, pero en esencia eran y son las mismas formas de invocarnos. Hubo gente migrando, buscando donde asentarse para salvar la vida, el conocimiento, las historias y el arte. Y lo lograron, se expandieron en el territorio y con el tiempo fueron haciéndose pueblos separados, con idiomas diferentes, con formas distintas de hacer su ropa, de acceder al conocimiento, de nombrar las cosas.

Esta es una tierra llena de volcanes, de montañas y de barrancos. El mapa ahora nos dice que es un país pequeño, cuando en realidad esta tierra es grande, Esperanza, pero está arrugada. Por eso las distancias no dejan de ser largas, porque siempre hay

$$
\text { Guia para mentoras de Abriendo Oportunidades }{ }^{(3)}
$$


montañas en los caminos, porque los caminos no son rectos, y los pueblos se esconden en las faldas de los volcanes, que son quienes los cuidan.

Escucha, escucha con atención en las ramas.

Y Esperanza escuchó que las aves decían nombres. No solo cantaban: los pájaros que eran diferentes entre sí, y decían:

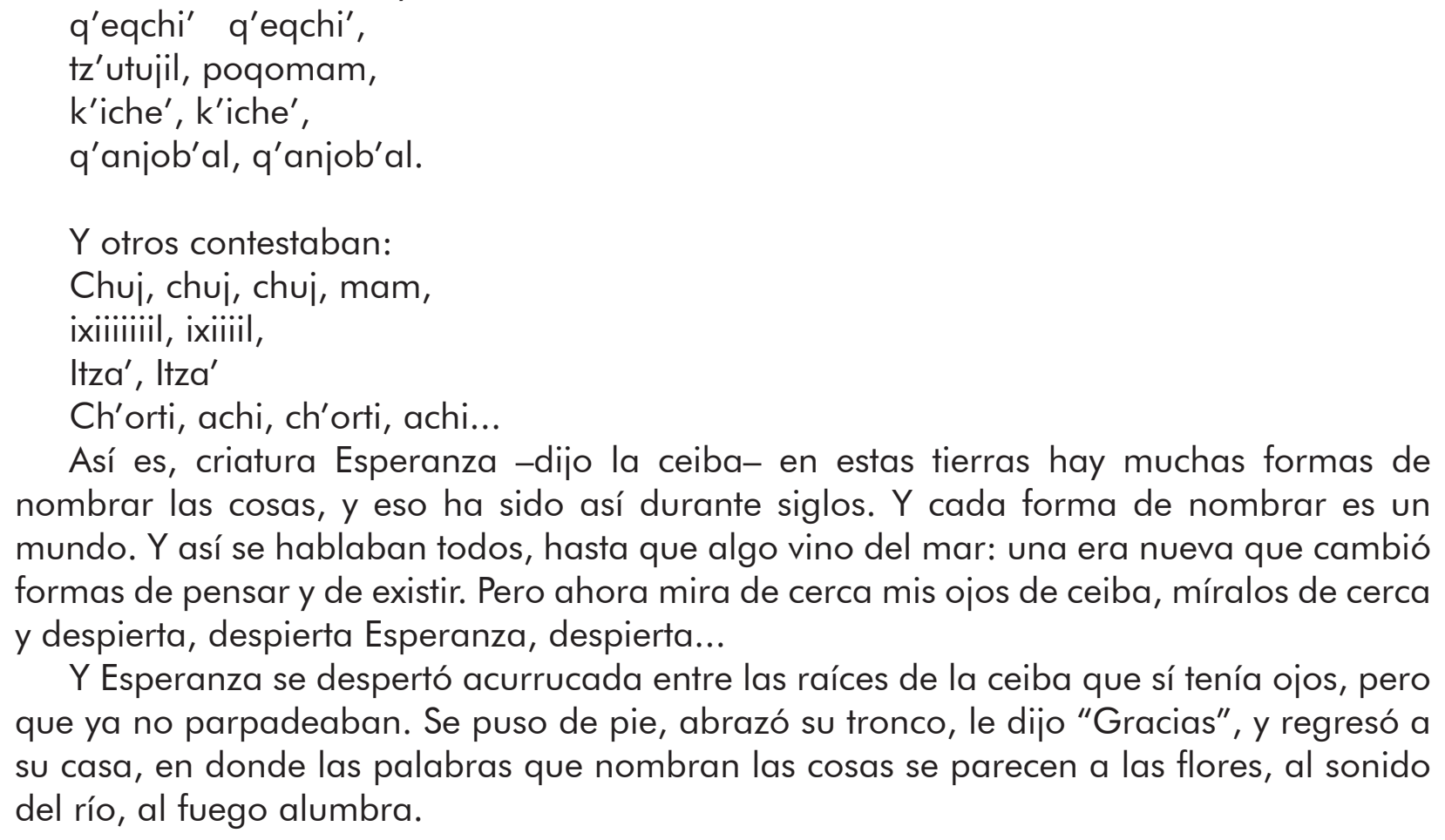

Así es, criatura Esperanza - dijo la ceiba- en estas tierras hay muchas formas de nombrar las cosas, y eso ha sido así durante siglos. Y cada forma de nombrar es un mundo. Y así se hablaban todos, hasta que algo vino del mar: una era nueva que cambió formas de pensar y de existir. Pero ahora mira de cerca mis ojos de ceiba, míralos de cerca y despierta, despierta Esperanza, despierta...

Y Esperanza se despertó acurrucada entre las raíces de la ceiba que sí tenía ojos, pero que ya no parpadeaban. Se puso de pie, abrazó su tronco, le dijo "Gracias", y regresó a su casa, en donde las palabras que nombran las cosas se parecen a las flores, al sonido del río, al fuego alumbra.

Discutan el cuento y la enseñanza que nos deja. Pueden usar como base estas preguntas, que tú podrás completar durante la conversación:

- ¿Pudieron identificar qué decía el canto de los pájaros?

- ¿QQué tienen en común las ramas de una ceiba? ¿Qué comparten?

- ¿Qué tienen en común los pueblos originarios que hoy habitan en Guatemala?

Reflexiona con las niñas una de las enseñanzas de este relato: las diversas ramas y los pájaros que cantan en ellas simbolizan a los pueblos originarios. Están vivos, aquí y ahora. Tienen un origen y una historia común, que los une a pesar de su diversidad: esto se representa en el tronco y las raíces. 


\section{Hagamos algo juntas}

Esta es una de las grandes preguntas que se hace cualquier ser humano:

- ¿̇De dónde venimos?

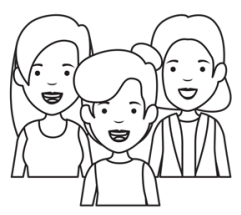

Para una pregunta tan amplia -como las que le gustan a Esperanzapodemos encontrar muchísimas respuestas. En este caso, podríamos responder de dónde viene el pueblo del que formamos parte, pero también de dónde viene cada una de nosotras como individuo. En esta actividad pensaremos específicamente en nuestra familia, y para ello realizaremos un árbol genealógico.

Explícale a las niñas que un árbol genealógico es una forma gráfica y divertida para ubicar a nuestros antepasados. Gracias a esta herramienta, podemos organizar la información de nuestra familia y aprender más sobre su origen.

Cada participante del grupo deberá realizar su propio árbol genealógico, y podremos elaborarlo usando la imagen literal de un árbol. En un papelógrafo, podrás poner la muestra, explicándoles lo siguiente:

1. Dibuja un árbol donde todas lo vean. Asegúrate que tenga un tronco amplio, muchas raíces en la parte inferior y varias ramas en la parte superior. Dibuja también sus hojas y algunos frutos.

2. Traza una línea vertical en el centro del tronco, y explícales que una mitad corresponderá a su mamá y la otra a su papá.

3. Las ramas las representarán a ellas y a cada uno de sus hermanos y hermanas.

4. Las raíces corresponderán a sus abuelos y sus demás antepasados.

Puedes poner el ejemplo haciendo tu propio árbol, y será necesario que incluya los siguientes datos:

- Nombre

- Lugar de nacimiento

Las niñas pueden elaborar el suyo en una hoja que tú les entregarás, o bien en un papelógrafo. Pídeles que sean creativas y que se esfuercen en la calidad del dibujo. Cada una de ellas se lo llevará a casa y le pedirá a sus padres o familiares que les ayuden a completarlo lo mejor que puedan. Sería magnífico que además del nombre y lugar de nacimiento de sus abuelos y abuelas, pudieran ir más atrás: bisabuelos, tatarabuelos, etc. Pídeles que lo traigan lleno la próxima semana.

$$
\text { Giva para mentoras de Abriendo } O_{\text {portunidades }}{ }^{\circledR}
$$




\section{Oportunidades en casa}

Recuerda que es importante involucrar -en la medida de lo posible- a los padres de las niñas en este proceso de crecimiento y aprendizaje. Por eso, en una hoja que les entregarás, las niñas desarrollarán esta actividad en casa. Recuérdales que se lo cuenten a sus papás lo más pronto posible, para que no se les olvide.

1. Cada una de las niñas le preguntará a su mamá, a su papá o a un pariente cercano, si ha tenido la posibilidad de conocer algún pueblo o ciudad de Guatemala en que se hable otro idioma maya. Las niñas deberán anotar a qué pueblos o ciudades hacen referencia, y de ser posible identificar qué idioma es el que se habla ahí.

2. Durante la conversación con sus padres o familiares, deberán preguntar y anotar los detalles de la experiencia que ellos les cuenten. ¿Cómo fue? ¿Cómo se sintieron? ¿Lograron comunicarse bien con las personas?

3. Anoten cómo se escriben estas cinco palabras en q'eqchi':

- Agua

- Fuego

- Montaña/cerro

- Casa

- Cielo

- Pájaro

4. Con ayuda de sus familiares, traten de averiguar cómo se dicen esas mismas palabras en los idiomas k'iche', mam, tz'utujil, q'anjob'al e ixil.

Al inicio de la próxima sesión, podrán poner en común los resultados de su trabajo en familia, y completar las palabras que no hayan encontrado.

\section{Ruta hacia un proyecto comunitario}

Es momento de decidir todas juntas qué harán para su proyecto comunitario, y eso es algo muy emocionante, pues dedicarán mucho tiempo y mucho entusiasmo para preparar entre todas una idea que sea útil para la comunidad.

Empieza esta última actividad del día recordándole a las niñas las ideas que pusieron en común la semana anterior respecto al proyecto comunitario. Pregúntales si se les ha ocurrido algo más para poder desarrollar el proyecto juntas.

En un lugar visible, ve anotando todas las ideas y empieza una discusión con todas para ir escogiendo la mejor opción. Es importante que tomen en cuenta la capacidad de recursos y de tiempo que tengan disponible, para que no haya ningún inconveniente durante las siguientes semanas. 
Cuando hayan discutido lo suficiente, tomen una decisión. Voten o lleguen a un consenso. Este será el primer paso en la ruta del proyecto comunitario.

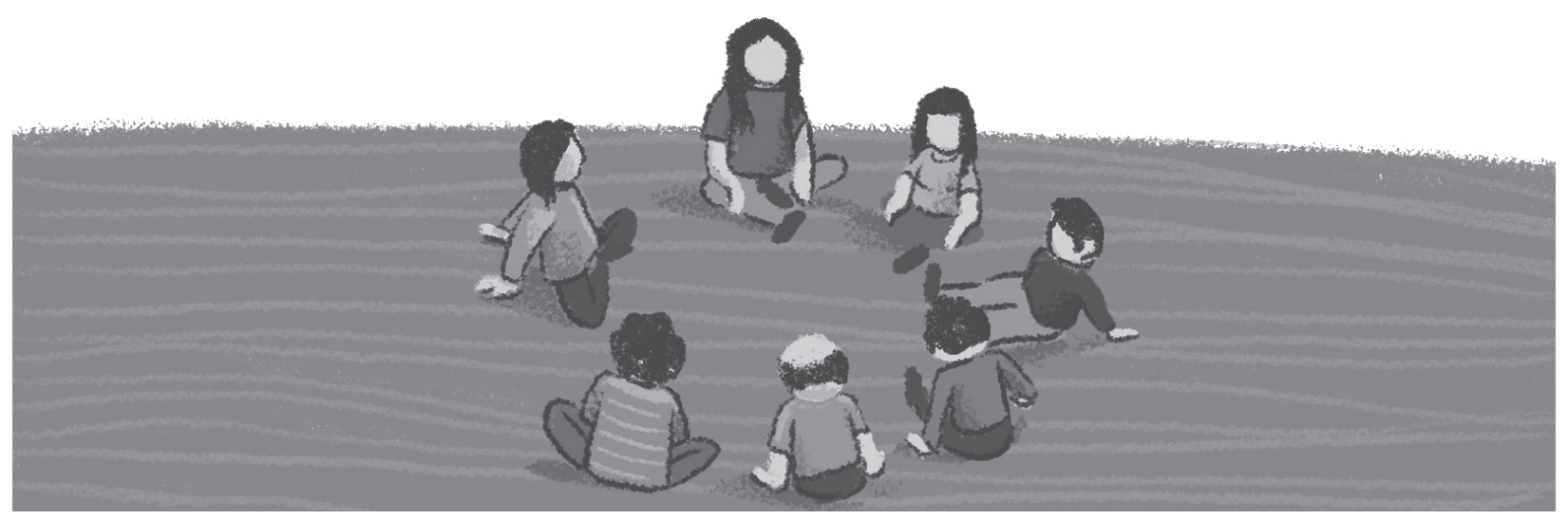




\section{Sesión 4}

\section{Una sensación que nos viene de muy lejos}

Es nuestra cuarta sesión, y seguiremos caminando junto a Esperanza por la historia de nuestros pueblos y nuestros territorios. Conforme se integran las niñas al grupo, pregúntales cómo les está yendo en la escuela, qué han aprendido en los últimos días y cómo se llevan con sus maestros y maestras.

\section{Hagamos memoria}

Cuando todas estén juntas, trata de que las niñas recuerden lo que hicieron la semana pasada. La tarea que les había quedado para realizar durante la semana era una lista de palabras en otros idiomas mayas. Pídeles que compartan su experiencia. ¿̇Pudieron encontrarlas todas? Que cada niña vaya diciendo las palabras en voz alta, aunque no sepan exactamente cómo se pronuncian. La idea es que las diferencias entre los idiomas se escuchen en el salón, porque al terminar la actividad deberás remarcar que esta diversidad de idiomas y de pueblos fue la que recibió la invasión española.

Como una actividad lúdica, pídeles a todas que lean su lista de palabras al mismo tiempo, que la lean una y otra vez mientras caminan por el salón. La idea es que se arme un ruido con la voz de todas las niñas. Después de un momento, grita iSilencio! Y cuando ese silencio sea total léeles este texto:

Y así fue como hablaban las personas en estas tierras. Eran distintos pueblos pero todos tenían el mismo origen. Como el árbol al que le crecen sus ramas desde un mismo tronco. Pero algo pasó: se empezaron

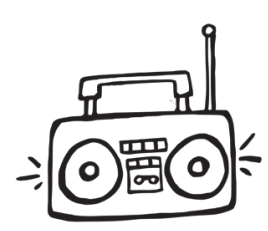
a escuchar historias que venían de los lugares cercanos al mar. Decían que venían unas naves con gentes diferentes, con la piel, el pelo y las ropas diferentes, con otro idioma, uno que nunca habían escuchado, con un dios del que no sabían nada, y que avanzaban por el mar y llegaban a las costas de lugares lejanos. Decían que iban avanzando, que se iban acercando a los lugares que conocemos, que iban a llegar a las casas de la gente, que tarde o temprano iban a llegar las personas que venían del otro lado del mar.

Toma en cuenta lo siguiente: lo que estás relatando es uno de los sucesos más determinantes en la historia de la humanidad. Es el encuentro, el choque de dos mundos, de dos formas de entender la vida, el tiempo, la muerte, todo. Por eso debes poner especial énfasis en la forma en que lo relatas. 


\section{Nuestras grandes preguntas}

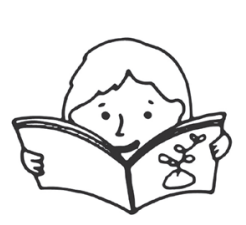

Después, pregúntale a las niñas si alguna vez han presentido algo, si les ha pasado alguna vez que sienten como si supieran algo pero no pueden decirlo con palabras: sólo lo sienten, a veces en el pecho, a veces por las cosas que les pasan en sus sueños, a veces con cosas que ven en la naturaleza.

Deja que dos o tres niñas cuenten si han tenido esa sensación. Es importante que sepan que la comunicación no se da solo entre personas, sino con lo que nos rodea, con los árboles, el cielo, los ríos, con todo. También tienen que tener claro que muchas veces uno se comunica con su propia memoria, con la memoria de nuestro pueblo, con nuestros antepasados y con las personas que ya no están entre nosotras pero que nos dejaron sus ideas, sus voces, sus historias.

Cuéntales que se están preguntando esto porque hoy vamos a hablar de los instantes previos a la invasión española, que empezó en nuestras tierras en el año 1524 hace casi 500 años-. Las tropas españolas, comandadas por Pedro de Alvarado, fueron acercándose y los pueblos se comunicaban entre sí. Aunque todo era más lento, se sabía que en los primeros lugares a los que habían llegado -las islas del Caribe- hubo batallas para tomar las riquezas por la fuerza. Se sabía que iban avanzando, que habían llegado a otras ciudades. Entonces, la gente empezó a sentir, a intuir, a imaginar lo que iba a pasar.

También se oían historias extrañas: algunos decían que veían a una mujer que lloraba a gritos por lo que iban a hacer con sus hijos, otros decían que habían visto a un hombre con dos cabezas, también empezaron a ver señales en el cielo, líneas de fuego que lo atravesaban, y todos sentían que el cielo les estaba diciendo que se prepararan.

Pregúntales a las niñas si conocen el nombre de esa sensación de que algo va a pasar. Si no lo dicen, cuéntales que algunas personas le llaman barajusto, y que es una información que se percibe, que ya está adentro del cuerpo, pero que aún que no podemos procesar, entender o interpretar. La idea es que al final de esta actividad las niñas comprendan la emoción colectiva que estaba desatando la llegada de los invasores.

\section{Hagamos algo juntas}

Explícales a las niñas que muchas veces lo que sentimos tiene que

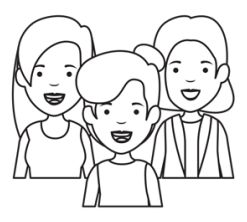
ver con hechos del pasado. Parece extraño, pero es cierto, porque la historia se acumula en los cuerpos, en las comunidades, en las culturas. Un acontecimiento importantísimo en la historia de todos nuestros pueblos sucedió en 1524. Pregúntales si la fecha les recuerda algo, si se las han mencionado en la escuela.

$$
\text { Giva para mentoras de Abriendo } O_{\text {portunidades }}{ }^{\circledR}
$$


Comparte con ellas, de forma creativa los siguientes acontecimientos. Puedes hacer una línea de tiempo, hacer dibujos en un pizarrón o un papelógrafo, o buscar imágenes en internet y presentárselas en una pantalla:

1. Cristobal Colón llegó a las islas del mar Caribe a finales de 1492. Desde entonces, los reyes de España organizan expediciones para invadir y conquistar las tierras que empezaron a llamar "Indias Occidentales", el enorme continente que hoy se llama América.

2. Poco más de 20 años después, las tropas españolas llegaron a conquistar los territorios actuales de México y Guatemala.

3. Antes de que eso sucediera, los pueblos del Golfo de México tuvieron noticias de la llegada de los españoles, y previnieron a los pueblos que aún no habían sido invadidos.

4. Hernán Cortés venció a los aztecas en 1521 y mandó a Pedro de Alvarado a luchar contra los pueblos de lo que hoy es Guatemala.

5. Pedro de Alvarado llegó a Zapotitlán (en lo que hoy es el departamento de Suchitepéquez), el 16 de febrero de 1524.

6. Subió las montañas y llegó a tierra fría y alta de la actual Quetzaltenango el 20 de febrero. Ahí los guerreros k'iche' los estaban esperando, y en ese lugar se dio la primera batalla para defender el territorio. Murieron muchísimos guerreros, entre ellos el capitán de las fuerzas k'iche': Tecún Umán.

7. Unos días después, la segunda batalla fue en Olintepeque. Cuentan los abuelos que la sangre que se derramó fue tanta, que el río que estaba cerca se tiñó de rojo. Por eso, ahora se llama Xekijel, que quiere decir "río de sangre".

8. El 7 de marzo, los españoles llegan a Utatlán en donde también hubo una batalla y luego tomaron el lugar.

9. El 13 de abril, los españoles llegaron a Iximche -la capital de los kaqchikeles-y luego parten a lo que ahora conocemos como Santiago Atitlán y a la costa sur del país.

10. Pedro de Alvarado aprovechó las diferencias de los pueblos que habitaban en este territorio -y las guerras que había entre ellos- para ponerlos a pelear entre sí. Esa fue parte de su estrategia para ir ganando terreno y poder.

11. A partir de esas batallas sangrientas inició para nuestros pueblos una larguísima historia de lucha y resistencia contra la violencia, el abuso y el despojo de los invasores.

12. Este momento dramático fue también el nacimiento de seres nuevos, de un pueblo mezclado, con dos orígenes: maya y español. Muchas mujeres fueron violadas y tuvieron hijos mestizos, que empezaron a llamarse ladinos.

13. A partir de entonces las ideas y formas de ver el mundo se vieron confrontadas, se obligó a todos a hablar el idioma del invasor (que era el español) y a contar el tiempo de otra forma. Se cambiaron los nombres de los lugares y se impuso una nueva religión: la religión cristiana.

14. A pesar de este cambio dramático, los pueblos mayas siguieron hablando su idioma, guardando sus ritos y sus dioses dentro de los rituales de la nueva religión, conservando sus tejidos y sus conocimientos ancestrales, que siguen vivos en su cuenta del tiempo, 
en su forma de sembrar, en su conocimiento del cosmos.

15. De pronto, este territorio se hizo parte del Virreinato de la Nueva España, con sede en lo que hoy es la Ciudad de México, y de la Capitanía General de Guatemala, cuya capital se movió muchas veces.

16. La invasión no fue igual en todos los pueblos. En el caso de las Verapaces se hizo una conquista religiosa, con la biblia y sin batallas. También los pueblos pusieron resistencia, pero de formas diferentes. La conquista de las tierras que hoy habitamos solo fue posible por medios pacíficos. Por eso se les llamó después Verapaz.

17. Después de compartir con las niñas todos estos puntos, invítalas a escuchar esta canción del grupo mexicano Porter, cuya letra tiene que ver con la llegada de los españoles. Al terminar de escucharla, pregúntales si la entendieron y cómo la relacionan con todo lo que acaban de aprender.

\section{Los relatos de Esperanza}

Hoy conoceremos algo muy importante que ha pasado en la vida de Esperanza. Pongamos mucha atención:

\section{El mito de jade}

Para Esperanza, estas semanas han sido intensas: se ha llenado de preguntas, pero también ha encontrado espacios que la han hecho crecer. Sus diálogos con la vida, con la montaña y con el fuego han sido una forma nueva de ver el mundo. Hace unas semanas, Esperanza

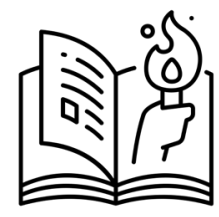
recibió una invitación para ser parte de un grupo de niñas que se reúnen a aprender, a hacer cosas juntas, a estar felices y seguras en un espacio para crecer. ¿̇Cómo se llama el programa? Abriendo Oportunidades ${ }^{\circledR}$. En las primera sesiones a las que asistió, Esperanza hizo nuevas amigas y se encontró con algunas niñas que ya conocía. Con ellas ha hablado de cosas que no había hablado antes, y se siente muy feliz con su mentora, se llama Quetzalí. Ella es la encargada de enseñarles cosas nuevas, escucharlas y compartir con todas su experiencia de vida.

En la escuela, Esperanza ha seguido aprendiendo, pero las dudas que tiene no siempre tienen respuesta. Por las reacciones de su maestra, pareciera que hay cosas que no deben preguntarse. Por ejemplo, la maestra dice que en Guatemala toda la gente habla español, que hay otros idiomas pero que el más importante es el español. A Esperanza esto la confunde, pues aunque habla español, su idioma es el q'eqchi'. En ese idioma piensa, en ese idioma sueña, en ese idioma habla con la gente que más quiere, con el agua, con las flores. También la maestra dijo que cuando llegaron los españoles llegó la civilización, y a ella su Tata Lix y el fuego le contaron de las ciudades hermosas, de los conocimientos científicos, de la cuenta del tiempo que se habían creado acá muchísimos años antes. ¿̇Por qué entonces se dice que la civilización vino con los invasores?

$$
\text { Giva para mentoras de Abriendo } O_{\text {portunidades }}{ }^{\circledR}
$$


Las preguntas se le amontonan. Pero esta semana tiene un plan: cree que si le pregunta cosas a su mentora Quetzalí, quizá ella pueda darle otras respuestas. El sábado después de la sesión, Esperanza le contó sus inquietudes a Quetzalí. Ella la escuchó con atención y con cariño, y le dijo que estaba muy bien que sospechara de cualquier persona que no permitía preguntas.

- Lo que pasa -dijo Quetzalí- es que la violencia de una conquista como la que se vivió aquí no es solo de armas y de sangre, es también de ideas, y esa violencia es mucho más larga que una batalla.

Poco a poco, Esperanza y sus amigas fueron rodeando a Quetzalí mientras ella hablaba:

-Aunque todo pasó hace siglos, la invasión sigue entre nosotros, porque aunque ellos hayan ganado tierras y se hayan quedado acá aprovechándolas, tuvieron miedo de perder el poder, por eso dicen "ESTA ES LA VERDAD", y cuentan su versión de lo que pasó, una y otra vez, hasta que se enseña en las escuelas; mientras tanto, la versión de los pueblos vencidos no se enseña, solo queda a salvo en las historias de nuestros abuelos, en nuestros rituales, en las cosas que sabemos y recordamos. La versión de los que ganaron las batallas e impusieron su forma de ver la vida se cuenta como la única verdad. ¿̇ ustedes también les han dicho que la civilización vino con la conquista, verdad?

-Sí, Quetzalí -respondieron algunas niñas.

-A mí también me dijeron lo mismo, pero la civilización había nacido aquí muchos siglos antes, como sucedió en otros lugares. En todo caso, la historia hizo que se mezclaran las formas de aprender, de hablar, de contar, de comer. Eso ha pasado siempre, antes y después de la conquista. Se ha dicho que nuestros hermanos mestizos son otro pueblo, uno muy diferente porque nacieron de padres españoles... Pero no, ellos tienen la misma madre, son como nosotros; por eso no debería haber diferencias, no deberían tratarnos distinto, si hasta tenemos los mismos rostros y comemos lo mismo. Hubo un momento en que los niños mestizos crecían entre nosotros y no había diferencias, pero el invasor tenía que asegurar su poder, y se llevó a los mestizos y les dijo que eran otros, y que deberían estar muy felices de tener un poco de sangre española. Como si la sangre de su mamá no fuera también la que corría por sus venas.

"Ha sido una historia triste, es cierto. Lo que debió ser el encuentro de dos mundos, fue un trauma: muchísima gente murió. Hubo lugares, como las islas del mar Caribe, en donde los pueblos que estaban antes y durante la invasión fueron totalmente asesinados. Hay países en donde las comunidades quedaron escondidas mientras la llamada "civilización" crecía. Aquí, en Guatemala, el hecho de ser indígenas nos ha puesto a trabajar para otros, hemos sido despojados de nuestras tierras una y otra vez. ¿̇Pero saben qué?: estamos aquí, juntas, hablando con nuestras palabras; estamos en todas partes, en las ciudades, en los pueblos, en las aldeas.

"¿Se imaginan ustedes lo que habrán sentido las personas que habitaban en nuestra tierra al enterarse de que el mundo como lo conocían estaba a punto de dar vuelta? A veces creo que nosotras aún sentimos ese susto, que la violencia de ese cambio sigue estando adentro de los que nacimos después. Pero hemos resistido y seguimos vivos. Tiene que llegar el día en que nuestras historias también se cuenten en la escuela. Que contemos el miedo, que contemos el dolor, pero también la esperanza, la fuerza y la resistencia. 
Las palabras de Quetzalí daban vueltas en la cabeza de Esperanza. Le gustaría que su mentora conozca a su abuelo, casi los imagina sentados platicando los tres.

-Fíjense que un amigo mío me mostró una canción que acabo de aprender en la guitarra -les dijo Quetzalí-, y esa canción tiene que ver con todo esto que estamos hablando, żla quieren escuchar?

-Siíí -dijeron todas.

Emocionadas, las niñas hicieron un círculo alrededor de su mentora y, mientras la luz naranja del sol se ocultaba, escucharon las notas de El mito de Jade, imaginando ese momento previo al encuentro de dos mundos:

En el siguiente enlace encontrarás la canción:

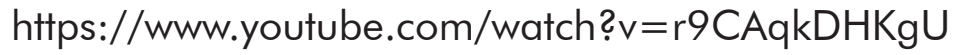

\section{Oportunidades en casa}

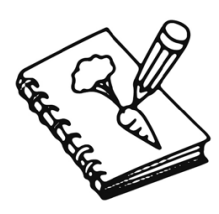

Entrégale a cada niña una hoja en blanco, que deberán llenar en casa - de ser posible con la ayuda de sus padres o sus familiares-. Tendrá las siguientes preguntas:

- ¿̇Han visto alguna invasión?

- ¿En dónde?

- ¿̇Ha habido personas que resisten y tratan de evitar las invasiones?

- ¿̇Enfrenta nuestra comunidad alguna invasión?

- De ser así, ¿̇cómo podríamos ayudar a defenderla?

Trata de compartir tu experiencia y de preguntarles si ellas alguna vez han sentido alguna amenaza.

\section{Las palabras que nos nombran}

Para cerrar la sesión, les leerás este fragmento de un libro que nos cuenta la historia del país, y que con un lenguaje muy hermoso cuenta lo mismo que acaban de aprender. El libro se llama Guatemala, las líneas de su mano, y lo escribió uno de los poetas más importantes de nuestro país: Luis Cardoza y Aragón.

\section{Guatemala, las líneas de su mano (fragmento) Luis Cardoza y Aragón}

Pedro de Alvarado, halcón sudoroso y sin fatiga, entró en la historia por las puertas del crimen, al mismo tiempo que alzaba su copa llena de armadas, ciudades y semillas. Las llamas de Gumarcaah reverberarán para siempre sobre su armadura.

$$
\text { Giva para mentoras de Abriendo } O_{\text {portunidades }}{ }^{\circledR}
$$


Disparado por el arco quiché, Tecún cruza un instante el cielo de Guatemala, el de una flecha amorosa. La sangre de Gumarcaah perdurará tanto como los relieves de las estelas...

Al terminar la lectura, conversa con ellas y pon a prueba su conocimiento. Trata de hacer una comparación entre la conquista violenta que se dio en el occidente de Guatemala (a partir de 1524) y la conquista pacífica que se dio más de un siglo después en las Verapaces.

Concluye la sesión deseándoles que su semana sea buena, y recuérdales que se volverán a encontrar en unos días. Diles que no olviden que juntas desarrollarán un proyecto comunitario, y la próxima semana hablarán más de él. 


\section{Sesión 5}

\section{Vivir en una sociedad colonizada}

¿Están listas para continuar caminando por nuestra historia? Recibe con entusiasmo a las niñas. Esta es la quinta sesión, y el proceso de aprendizaje debe continuar.

\section{Hagamos memoria}

Luego de saludar a las niñas y de darles la bienvenida a la sesión, pregúntales qué recuerdan del último relato de Esperanza. Ayúdales a refrescar su memoria: Esperanza se integró a un grupo de Abriendo Oportunidades ${ }^{\circledR}$ y junto a sus compañeras escuchó una canción que habla de un momento muy importante de nuestra historia: el choque de dos mundos, ocurrido en 1524. Repasa muy brevemente los acontecimientos y los datos que compartiste con ellas en la sesión anterior.

\section{Nuestras grandes preguntas}

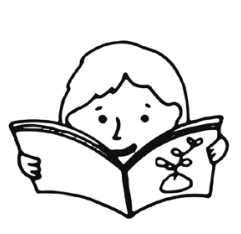

Les presentarás a las niñas tres pares de fotografías. Puedes imprimirlas y pegarlas frente a ellas en el salón, puedes proyectarlas sobre una pared, o puedes entregárselas en hojas individuales.

Las fotos mostrarán lo siguiente:

1. Una aldea cercana a Chisec y una ciudad.

2. Una mujer joven que viste un güipil y una mujer joven que usa un vestido europeo.

3. Un plato de kaq'ik y un menú de Pollo Campero.

Al mostrarles cada par de fotos, deberás preguntarles cuál les gusta más, cuál es mejor, cuál les atrae, y por qué. Es importante que la mayor cantidad posible de niñas se exprese y explique qué las motiva a escoger una de las dos imágenes.

Luego, coméntales que muchas veces la forma en que vemos el mundo, en que escogemos lo que nos gusta, está dictada por alguien más -aunque no nos demos cuenta-. Y, por lo general, esas preferencias que nos imponen desde fuera suelen ser violentas. Se hacen clasificaciones entre personas, espacios y cosas, y se determina que unas son mejores que otras. Pero esas clasificaciones no son justas, y debemos reconocerlas para poder criticarlas y liberarnos de ellas. 
Cuéntales que hoy hablaremos de las divisiones que se generaron en Guatemala durante la época colonial. Y así podremos identificar que muchas actitudes que vemos en nuestro día a día tienen su origen en esa época lejana. Déjales bastante claro que es importante cuestionarnos la forma en que vemos el mundo.

\section{Los relatos de Esperanza}

Como todas las semanas, hoy conoceremos algo que le pasó a Esperanza, esa niña que comparte muchas cosas con cada una de las niñas de tu grupo de AO. Pídeles que escuchen con atención:

\section{¿Por qué en otros lugares nos tratan diferente?}

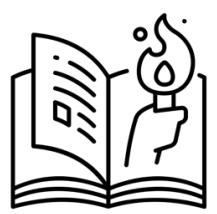

Era una madrugada tibia, y Esperanza se levantó muy temprano. Debía alistarse rápido, pues esa mañana acompañaría a su abuelo a Cobán. El camino es largo, difícil; ahora incluso deben tomar una balsa para atravesar una pequeña laguna que se formó hace meses, cuando pasaron dos huracanes muy fuertes que desaparecieron algunos caminos.

Don Lix está muy preocupado, al igual que muchas personas de la comunidad, porque el caudaloso río que ha pasado siempre por sus tierras está perdiendo fuerza, se está secando. Aunque al principio pensaron que eso se debía al inicio de la estación seca y calurosa, pronto se dieron cuenta que no era cosa de la naturaleza.

Las grandísimas plantaciones de palma africana necesitan mucha agua y parece que los dueños de esas plantaciones quieren adueñarse de absolutamente todo. Por eso decidieron desviar un río, ese río que pasa por la aldea de Esperanza. Han sido días muy activos para la comunidad: se han puesto a pensar juntos qué hacer para enfrentar este problema tan grande.

Don Lix es una persona muy respetada en la comunidad. La gente lo quiere, le pide consejo. Él habla con el fuego y entiende cosas que la naturaleza dice. Durante los últimos días ha platicado con personas que quizá puedan ayudarlos legalmente. Para eso ha tenido que viajar a Cobán, la cabecera departamental, la ciudad más cercana. Esta vez, don Lix tenía que ir a la ciudad porque además de ser zapatero, lleva las artesanías de madera que hace la gente en su aldea y las vende a ciertas familias que conoce desde hace muchos años.

Ese día Esperanza se fue con él, pues así aprovecharían mejor el tiempo. Aunque aún estaba oscuro cuando empezaron el camino, la madrugada tiene un color distinto al de las horas de la noche, pensaba Esperanza, como si las estrellas estuvieran más bajitas, como si las nubes cambiaran de forma. Se subieron a un picop con los encargos que iban a entregar, y don Lix llevaba en su mochila los papeles que le servirían en sus trámites. Esperanza podía ver en sus ojos que estaba preocupado y triste.

Llegaron a una especie de muelle que hace poco no existía, en un camino que había quedado hundido en la profundidad del agua que llovió hace varios meses y que todavía estaba ahí. A Esperanza esto le hacía volar la imaginación: se entretenía pensando que 
todo el paisaje que veía se sumergía en el mar. Se imaginaba nadando encima de las montañas. "Eso sería como volar", pensaba. Cuando iban a medio camino sobre la pequeña balsa, ya era totalmente de día.

-Cuesta llegar a Cobán, ¿̇verdad mijita? Parece que no quisieran que uno llegue -le decía su abuelo, pensando en que después debían tomar un bus, subir y bajar montañas, pasar por distintos pueblos.

A Esperanza Cobán le producía sensaciones extrañas: las calles anchas, el ruido de carros, la gente con la cara un poco triste o enojada, y siempre como con prisa. Aunque le gustaba viajar y ver otros lugares, a veces sentía de una forma muy clara que ese no era su lugar. Después del cansancio del trayecto, todavía tenían que esperar en los semáforos, escuchar bocinas, respirar humo. Cuando se bajaron del bus, su abuelo empezó a revisar sus papeles. Iban a ir con un abogado.

A Esperanza ser nieta de Don Lix le daba mucho orgullo. Era un señor importante, que iba a arreglar asuntos importantes. Él se vio en el reflejo de un vidrio, revisó su pelo, se sacudió el saco y se dispusieron a entrar a una oficina. "Tata Lix es importante", seguía pensando ella. Pero adentro de la oficina no parecían darse cuenta de eso. De hecho, parecía que no se querían dar cuenta de que ellos habían entrado.

-Señorita, por favor dígale al Licenciado Hipólito Mazariegos que venimos de lejos, que ya lo habíamos llamado y que es urgente que nos reciba, porque el río se nos está muriendo, y atrás de él vamos nosotros si no logramos arreglar este asunto - dijo don Lix.

Pero la señorita le respondía sin levantar la cara, viendo solo la pantalla de su computadora.

Esperanza sintió tristeza y enojo en su pecho, casi lloraba. Se imaginaba diciéndole a la secretaria que no se dignaba a ver a su abuelo que él era su Tata Lix, un señor importante, que la gente le pedía consejo, que hablaba con el fuego y el fuego le contestaba, y ella ni siquiera podía levantar la cara para hablarle.

Estuvieron sentados más de lo que esperaban, pero finalmente los hicieron entrar a la oficina del Licenciado Hipólito Mazariegos, como decía un rótulo de letras doradas, a la par de la pintura de una mujer con una balanza en la mano y los ojos vendados.

Adentro fue peor aún. El Licenciado le decía a Don Lix otro nombre: Andrés. Le hablaba casi riéndose, y como con lástima. En resumidas cuentas, le decía que así eran las cosas, que mejor aceptara el dinero que los dueños de las plantaciones le ofrecían, que tal vez no era mucho pero que la verdad era mejor no meterse con ellos.

-Usted tiene que entender, Andrés, que cuando ellos llegan es mejor no hacerles problema. Imagínese que por andar ustedes ahí de enojados con ellos, capaz y los terminan desalojando -decía el abogado.

Don Lix prefirió no insistir. Esperanza salió triste, enojada, indignada. Trataron mal a su abuelo, no hicieron nada para ayudarlos, en realidad de lejos se veía que no les importaba el problema de su comunidad. Pero su abuelo le dijo que así era, que uno siempre tenía que estar listos a ser tratado así, pero que a eso solo se respondía de una forma: resistiendo, manteniendo los objetivos claros y luchando.

-Así que ahorita mismo te vas al comedor de doña Coralia, mijita. ¿̇Te acordás en dónde está? Ahí mero frente al parque. Vas y le entregás las cajitas de madera que encargaron. Ella se va a acordar de vos, y yo llegaré en un ratito, porque la quiero saludar.

$$
\text { Giva para mentoras de Abriendo } O_{\text {portunidades }}{ }^{\circledR}
$$


$-\dot{2} Y$ usted a dónde va, Tata Lix?

-A otra oficina, pero ahí la gente es más amable. Ahí seguro nos van a ayudar con los problemas de la tierra.

Se despidieron y Esperanza caminó con el encargo envuelto en telas de colores hermosos. Al llegar vio a doña Coralia, que estaba sentada en una de las mesas de su comedor haciendo cuentas. Cuando Esperanza entró y la saludó, la señora bajó un poco sus lentes para verla mejor y le dijo:

-iAy Esperancita, cómo creciste! ¿̇En dónde me dejaste a tu abuelito?

La niña no se recordada mucho de doña Coralia, pero le dio confianza. Sacó el encargo, la señora lo revisó y le dijo que le iba a pagar a su abuelo en cuanto llegara. Ahí con doña Cora -como le decían todos- estaba su nieta Patricia: una niña de la misma edad que Esperanza. Patricia muy amable con ella: le preguntó de dónde venía y le dijo que no conocía ese lugar; le preguntó en qué grado estaba y le dijo que ella estaba en el mismo; le preguntó si le gustaba Cobán y -antes de que Esperanza contestara- le dijo que ella prefería la capital, pero que en realidad quería vivir en una ciudad de Estados Unidos. Patricia era tan diferente a Esperanza: hablaba distinto aunque le entendía todo, le preguntaba mucho pero casi parecía que no le ponía atención cuando ella contestaba.

Luego de un rato, llegó al comedor de doña Cora una amiga de Patricia. Ella se la presentó a Esperanza, pero para ese momento ya se había olvidado de su nombre, y con otro tono le dijo a su amiga que venía a venderle artesanías a su abuela. Las otras dos niñas se reían y hablaban igual. Después de un rato, decidieron tomarse una foto con el celular de Doña Cora, y le pidieron a Esperanza que se moviera. No querían que ella saliera en la foto. Esto le hizo sentir una punzada en el corazón, otra, muy parecida a la que sintió cuando estaba con su abuelo en la oficina del Licenciado Hipólito Mazariegos.

En ese momento, llegó su Tata Lix. Habló muy amistosamente con doña Coralia, recibió el dinero, se despidió y salió con su nieta para emprender de nuevo el largo camino de regreso a su casa.

-Tata Lix, ¿̇por qué aquí nos tratan diferente? ¿̇Por qué no es como allá con nosotros?

-Ay, mija, ese trato empezó hace muchos años y hemos tenido que vivir con esto. Pero también hemos luchado para que se den cuenta de que no somos diferentes. Desde hace siglos, cuando le dijeron a las gentes mestizas que nosotros y ellos éramos distintos, todo ha sido más difícil.

$-\dot{z}$ Es por esto mismo que nos quieren quitar el río, Tata Lix?

-Pues sí, mija, de alguna forma sí. Como que hay gentes que creen que son superiores y se inventan sus derechos al mismo tiempo que nos quitan los nuestros. Pero mirá: aunque es triste, tenés que tener claro que lo más importante es estar seguro de algo: que no hay gente superior ni gente inferior, que vivir en el campo y en la ciudad no te hace más ni te hace menos, y sobre todo que debemos defender la tierra, la memoria, el agua, todo; porque si no cuidamos esas cosas, no cuidamos la vida.

$-\dot{2} Y$ todo esto cuándo empezó, Tata?

-Vamos a decir que hace siglos, mija, en una época que se le llamó colonial, en la que clasificaron a la gente, y empezaron a darle distinto trato por la forma de vestirse, por el idioma, por donde uno vive...

-¿̇Y cuándo se va acabar esa época colonial? 
Su abuelo se le quedó viendo, con los ojos tristes pero con una sonrisa.

-Se supone que ya acabó, mijita, pero hay problemas viejos que tardan en irse. Sino mirá, no estaríamos luchando ahorita por algo tan importante como el agua del río.

Todo el camino de regreso, Esperanza se fue pensando en Patricia, en el Licenciado Hipólito Mazariegos, en la ciudad y en su aldea... La cabeza se le llenó de preguntas, que al mismo tiempo parecían convertirse en respuestas.

Luego del relato, coméntalo con las niñas. ¿̇Han pasado ellas por alguna situación similar a la que le pasó a Esperanza?

\section{Recuerda tener claro lo siguiente:}

1. La llamada época colonial abarca casi 300 años. Se divide en dos fases: la mal llamada Conquista y la Colonia. Inicia en 1524, con las primeras batallas entre las tropas españolas y los guerreros 'k'iche' en el altiplano de Occidente, y finaliza formalmente en 1821, cuando se firma la independencia.

2. Una colonia se forma cuando un ejército invade un territorio que no le pertenece y somete a los pueblos que viven en él, anulando su libre determinación.

3. La situación colonial que afectó a Guatemala -y a todo el continente americano, en mayor o menor medida-empezó con la acción militar. Luego vino la acción económica, con el repartimiento de las tierras conquistadas y con la encomienda de gente para que la trabajara forzadamente). Después se dio la acción administrativa, por la que nuestros territorios pasaron a ser parte de la Corona Española -a través del Virreinato de la Nueva España, con sede en México; y del Reino de Guatemala, cuya capital se trasladó en varias ocasiones. Por último, vino la acción misionera, que mediante la religión afectó los modos de vida de los pueblos originarios.

4. Durante toda la época colonial, se clasificó a la población según las circunstancias de su nacimiento. Hubo muchísimas clasificaciones, pero las principales eran las siguientes: los peninsulares (españoles que llegaron a América) ocupaban los mejores puestos y acumularon propiedades; los criollos (hijos de españoles nacidos en América) ocupaban los puestos de menor importancia; los ladinos o mestizos (hijos de españoles con indias), quienes fueron creciendo en número y adquiriendo importancia; y los indios (término colonial para referirse a los diversos pueblos que ocupaban el territorio antes de la venida de los españoles, que fueron obligados a trabajar las tierras que les arrebataron.

5. Esta es una lista completa de los conceptos usados para definir a las personas en la época colonial:

Criollo: europeo en América

Mestizo: español e indígena

Castizo, castizo cuatralbo o cuarterón de mestizo: español con mestizo

Español: castizo con español

Zambo o jarocho: indígena con negro

Zambo prieto: negro con zambo

$$
\text { Giva para mentoras de Abriendo } O_{\text {portunidades }}{ }^{\circledR}
$$


Mulato: español con negro

Morisco (diferente a moriscos peninsulares) o cuarterón de mulata: mulato con español

Albino u octavón: español con morisco

Salta atrás o saltapatrás: albino con español

Apiñonado: mestizo con mulato

Cholo, coyote o meslindio: indígena con mestizo

Chino o mulaio obscuro: mulato con indígena

Galfarro: mulato con negro

Harnizo: español con cholo

Harnizo: castizo con mestizo

6. Durante esos 300 años se fundó la base de muchas circunstancias que nos afectan incluso ahora, 200 años después de la independencia.

Utiliza tu creatividad para compartir con las niñas algunos de estos datos.

\section{Hagamos algo juntas}

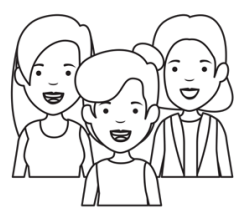

Ve con las niñas al patio más cercano, y encuentra un lugar en donde todas puedan pararse cómodamente. Dibuja -con un palito sobre la tierra o con un yeso sobre el cemento del patio- un cuadrado grande, dentro del cual puedan estar todas de pie. Explícales la dinámica:

1. Tú irás mencionando distintas situaciones que quizá les hayan pasado alguna vez en la vida.

2. Cuando la respuesta sea Sí, cada niña deberá ir saliendo del cuadro, y se irá colocando alrededor.

Cuando todas estén de pie, dentro del cuadrado, tú dirás:

- Si alguna vez las han tratado mal por el lugar donde viven, salgan del cuadro.

- Si alguna vez las han tratado mal por la ropa que usan, salgan del cuadro.

- Si alguna vez las han tratado mal por el idioma que hablan, salgan del cuadro.

- Si alguna vez han sentido algo como lo que sintió Esperanza en el cuento de hoy, salgan del cuadro.

- Si alguna vez las han hecho sentir mal por sus rasgos físicos, salgan del cuadro.

- Si nunca han ido a Cobán, salgan del cuadro.

- Si nunca han ido a la Ciudad de Guatemala, salgan del cuadro. 
La idea de esta dinámica es ver de una forma clara cómo hemos sido excluidas por la dinámica colonial que predomina en nuestro país, en donde se nos clasifica de manera violenta por las más distintas características. Al finalizar, todas podrán ver cómo se nos ha excluido del cuadrado, que representa la vida digna en sociedad.

Reflexionen juntas sobre lo que pensaron o sintieron al ver cómo se iba vaciando el cuadro. Explícales que esto no debería ser así, que nadie debiera ser discriminado por todas esas características que mencionaste. Diles que hubo un momento violento de nuestra historia, en que a todos nos empezaron a excluir, y pregúntales por qué si estamos a 200 años de que terminó la época colonial, estas cosas siguen pasando. Hay ideas violentas, impuestas desde fuera, que benefician a quienes tienen el poder, que tienen 500 años y nos siguen haciendo daño.

Luego, reúnanse de nuevo dentro del cuadro, y vean cómo el espacio se empieza a llenar de nuevo. Cuando cuestionamos las cosas que nos sacan del cuadro, podemos ser capaces de luchar contra ellas y encontrarnos nuevamente.

\section{Las palabras que nos nombran}

Hace muchos años, vivió en un pueblo llamado San Juan del Obispo, muy cerca de La Antigua Guatemala, un escritor que se llamaba Luis de Lión. A un amigo suyo le contó esta anécdota:

"Yo supe que era indio hasta que bajé a La Antigua; antes era persona".

Piensa junto con las niñas sobre el significado de esta frase. ¿̇Cómo se relaciona con lo que hemos aprendido hoy?

\section{Ruta hacia un proyecto comunitario}

Estamos a punto de terminar la sesión. Por eso, recuérdales a las niñas que deben ir avanzando en su proyecto comunitario. Ya han decidido qué tipo de proyecto harán, así que ahora deben fijar juntas los objetivos que planean alcanzar con su proyecto. Organiza una breve discusión al respecto, preguntándoles a todas:

\section{- ¿Qué queremos lograr con nuestro proyecto comunitario?}

Recuerda las respuestas y anótalas, pues te ayudarán a ir desarrollando el proyecto durante las próximas semanas. 


\section{Sesión 6}

\section{Una cadena de resistencias}

\section{Nuestras grandes preguntas}

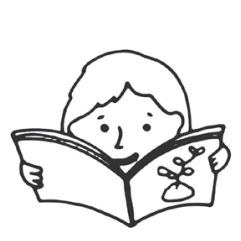

Saluda con alegría a las niñas, mientras se integran a la sesión. Trata de conversar con ellas respecto a lo que han ido aprendiendo a lo largo de este camino. Resuelve las dudas que surjan y enciende su entusiasmo por el proceso que están atravesando. Diles que todo este aprendizaje será útil para su vida en el futuro.

Cuando todas estén juntas, inicia una breve conversación en torno a esta pregunta:

- ¿QQué es resistir?

Lanza la pregunta a las niñas y observa sus respuestas. Puedes animarlas explicando que resistir es algo así como oponerse con fuerza a algo que nos hace mal, que no nos conviene. Trata de buscar ejemplos en la vida cotidiana. Diles que con el relato de hoy conocerán una experiencia muy interesante de alguien que resistió, hace más de 200 años, en el territorio que todas ustedes conocen.

\section{Los relatos de Esperanza}

Hoy conoceremos algo que le pasó a Quetzalí, la mentora de nuestra amiga Esperanza. Escuchemos todas con atención este relato:

\section{Una historia de las resistencias}

En los últimos días, Esperanza ha pensado mucho en su futuro. Las reuniones de su grupo de Abriendo Oportunidades le han hecho imaginar lo que quiere hacer con su vida. Ahora mismo, se imagina

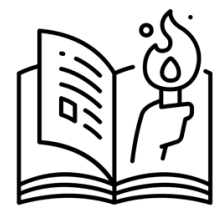
siendo arqueóloga. Esa es una profesión que tiene que ver con el pasado, son personas que estudian la cultura a través de los materiales que dejaron las personas o grupos que estuvieron acá mucho antes que nosotras, y a Esperanza le entusiasma conocerlas. Las conversaciones que ha tenido con la montaña, con el fuego, con la naturaleza misma, y todas las enseñanzas de su abuelo y de Quetzalí le han hecho sentir que es importante buscar las raíces de su pasado para imaginar un mejor futuro para ella, para su aldea, para su departamento y para su país. 
Como todos los sábados, Esperanza llegó temprano a su reunión, saludó a sus amigas y se sintió contenta de ver a Quetzalí. Pero Quetzalí esta vez se veía preocupada. Y no es para menos: el asunto del desvío del río tiene a toda la aldea intranquila. Han pedido ayuda y, la verdad, ha sido difícil.

Cuando llegaron todas las niñas, Quetzalí les dijo que hoy terminarían su sesión un poquito antes de tiempo, porque en el salón iba a haber una asamblea de la comunidad. Les contó del problema del río, y Esperanza sabía perfectamente bien de qué estaban hablando, pero algunas de sus amigas no.

Las niñas la escucharon con atención, y aunque Quetzalí estaba muy triste y enojada, sus ojos se llenaron de alegría al verlas tan atentas, preguntando sobre lo que podían hacer, indignadas con lo que les estaban quitando a ellas: el agua de un río, que no es de nadie, que es de la tierra, que es de la vida.

-Esta semana fui a Cobán -les contó Quetzalí- porque allá hay una organización que nos está ayudando para recuperar nuestro río. Hubo un momento en que me senté ahí en el parque y me sentí demasiado frustrada. "Por qué", preguntaba yo, "por qué a nuestro pueblo le han pasado tantas cosas malas; por qué tenemos siglos de ser maltratados; se nos juzga por todo, no tenemos acceso a lo mismo que otros, todo es más difícil". Y les confieso que el enojo se me hizo un nudo en la garganta, al pensar en los siglos de dolor que hemos vivido, no solo ahora por nuestro río, sino porque nuestros papás pasaron otras penas, nuestros abuelos otras, los abuelos de los abuelos otras... Pero siempre son el despojo, la invasión y la discriminación las que mueven esas penas que sufrimos.

Quetzalí seguía hablando, y las niñas la escuchaban atentas. Esto no era una sesión más, no era un contenido de la guía, sino la experiencia de su mentora:

-La verdad es que ahí, solita, me puse a llorar. Pero en ese ratito sentí como que alguien me levantaba la cabeza. Yo estaba ahí sentada en la orilla del arriate, vi para arriba, y entre mis lágrimas apareció la imagen de un hombre de piedra, viendo hacia el frente; encadenado, pero con un gesto de valentía. Era la escultura de Manuel Tot. ¿̇La han visto? ¿̇aben ustedes quién es Manuel Tot?

Las niñas no respondieron.

- Les voy contar su historia-siguió Quetzalí-. Él es un héroe de nuestro pueblo Q'eqchi'. Siempre fue cercano a la Iglesia católica, y por eso tenía que viajar constantemente a la Capitanía General de Guatemala. Con el tiempo, se fue armando un plan que se llamó Conjuración de Belén, en el que Tot participaría con otras personas. El plan consistía en acabar con el dominio de la Capitanía sobre los territorios de las Verapaces. Manuel Tot se convirtió en un líder importante, al punto de organizar una marcha en busca de la independencia con 15 mil indígenas q'eqchi' que se dirigirían de Cobán a la capital del reino. Ellos buscaron la libertad y la independencia de los territorios que hoy ocupamos nosotras, trataron de romper las cadenas que la colonia había impuesto a nuestros pueblos desde la invasión. Pero fueron traicionados y el capitán general de Guatemala se enteró de los planes y de lo que pretendían lograr.

Quetzalí se puso triste:

-Al verse descubierto, Manuel Tot tuvo que huir rumbo a México, pero estando en San Marcos, muy cerca de la frontera, cayó enfermo con fiebre. Estando ahí, las personas que tenía cerca realmente no sabían que él había sido organizador de la conjuración, pero

$$
\text { Giva para mentoras de Abriendo Oportunidades }{ }^{\circledR}
$$


de nuevo fue traicionado. Como se sentía muy mal, decidió confesarse con un sacerdote, temiendo que iba a morir pronto. En la confesión, le contó al padre que había sido parte de este movimiento que buscaba la libertad de su pueblo. El sacerdote, violando las leyes de la Iglesia, avisó a las autoridades para que lo capturaran. Lo mandaron a la capital, en donde estuvo preso, pero además fue víctima de torturas, porque no podían permitir que esta idea de libertad se multiplicara, que se repitiera un plan como ése. Porque si el pueblo $Q^{\prime}$ eqchi' recuperaba su territorio la Iglesia y la Corona, y las familias criollas perderían su poder.

- ¿̇Y qué le pasó a Manuel Tot, Quetzalí? -preguntó Esperanza preocupada.

-Entre la enfermedad, los golpes y el encierro, Manuel Tot murió el 11 de julio de 1815. Su último deseo fue que lo enterraran encadenado, porque así sabría toda la gente que murió luchando, y que su pueblo seguía luchando -respondió Quetzalí con orgullo-. Las cadenas son un recordatorio de las injusticias que pesan sobre el pueblo Q'eqchi' y, sobre todo, son un llamado para que todos los que quedaron vivos y los que nacieran después de él recordaran que tenían que romper esas cadenas.

El tiempo pasó volando. Las niñas se veían ente sí. Quetzalí concluyó:

-Todo esto que les acabo de contar lo recordé mientras a través de mis lágrimas vi la escultura de Manuel Tot ahí en el parque de Cobán. ¿̇Y saben qué? Yo me sentía sola, triste y frustrada, pero en ese instante me sentí acompañada, porque aunque no conocí a Manuel sí conozco su lucha, porque los años han pasado y siempre estamos en lucha por nuestra vida y por nuestra tierra. Comprendí que lo ideal sería no tener que luchar, pero también comprendí que esa lucha nos define como pueblo. A mí me define como mujer capaz de pensar en el pasado y el futuro de mi comunidad. Hoy Manuel Tot es un ícono, un símbolo, y sus cadenas son también las nuestras y por eso no debemos nunca, pero óiganme bien: nunca, dejar de lado nuestra búsqueda de libertad. Por eso peleamos por ese río, por eso aprendemos cosas juntas, por eso hablamos con el agua, el fuego y las estrellas: porque somos una comunidad que se acompaña de las voces del pasado y de la esperanza del futuro. Y aunque ahora mismo tenemos este problema, nada puede evitar que nuestra memoria y nuestra cultura sean las herramientas perfectas para buscar la felicidad de todos.

Esperanza escuchó a Quetzalí. Vio a sus amigas y todas tenían los ojos llorosos, todas pensaban en Manuel Tot, en su río, en las gentes con las que compartían la vida. Y Esperanza sintió un fuego, una caricia que la hacía sentir parte de algo más grande. Y eso más grande era su pueblo, el pueblo $Q^{\prime}$ eqchi', que ahora tenía claro que siempre iba a defender y a cuidar.

Antes de irse de vuelta a su casa, Quetzalí les dijo las niñas que hicieran un círculo, que cerraran los ojos y que en su mente hablaran con Manuel Tot, porque los muertos no dejan de existir: son ideas, son luchas, son sueños, son fuerza, les dijo. Y Esperanza lo imaginó en la orilla del río, pero ese río estaba caudaloso. En su imaginación le tomó las manos a Manuel y lo ayudó a quitarse las cadenas, y juntos las lanzaron al río, que corría tan fuerte que no alcanzaron a ver cómo se hundieron las cadenas, volviéndose parte del río que buscaba su camino hacia el mar.

Luego de compartir este cuento con las niñas, pregúntales qué les pareció. ¿Conocían ya 
algo sobre Manuel Tot? Las que han ido a Cobán, ¿̇recuerdan haber visto la escultura que se menciona en el cuento? Platica con ellas al respecto.

\section{Recuerda tener claro 10 siguiente:}

1. 1. Desde el momento de la invasión española, ocurrido en 1524, hasta el día de hoy, los pueblos originarios que habitan nuestro territorio han resistido y se han opuesto al despojo y a la violencia con que el poder ha querido dominarlos. Durante casi 500 años se ha mantenido una larga cadena de resistencias de distinto tipo, que busca siempre la dignidad de las comunidades, el cuidado de la Naturaleza y el bienestar para todas. El nombre de Manuel Tot es uno de los nombres que debemos recordar, junto con los de Atanasio Tzul (líder k'iche' de Totonicapán) y Mamá Maquín (como se conoce a Adelina Caal, lideresa asesinada en Panzós en 1978). De ser posible, investiga sobre las resistencias indígenas en Guatemala y completa la información que presenta el relato. Es importante que las niñas comprendan que hay muchos referentes de lucha, dignidad y resistencia a lo largo de la historia de nuestros pueblos.

2. Aquí hay una lista de alzamientos importantes durante la época colonial, sobre los cuales podrás saber más en internet:

- Alta Verapaz - Aj Pop Batz / Juan Matalbatz (1545)

Aj Pop Batz fue un guerrero del área q'eqchi' a principios de la llegada de los invasores. Él era el líder de un grupo de expertos en combate que se llamaban los aj jolomna. Es debido a estos guerreros que los Tlaxcaltecas (los indígenas de México que acompañaban a los españoles) le llamaron a las Verapaces Tezulutlán, la tierra de la guerra. En ese tiempo, muchos pueblos cayeron ante los españoles, pero no el pueblo de Aj Pop Batz -él mantenía el territorio.

Fue tal la desesperación de los españoles, que enviaron a frailes y sacerdotes católicos para hablar con los señores de Tezulutlán. Ellos estuvieron con varias pláticas con Aj Pop Batz, que finalmente decidió convertirse y convertir a varios de los señores. Fue bautizado como Juan Matalbatz.

De esta forma, una vez bautizado, fue a España a visitar a Carlos $V$-uno de los reyes españoles. La comitiva viajó a España y el rey se impresionó de verlos porque parecían "hombres de acero", ya que no sentían el frío de España. Se le pidió a Aj Pop Batz hincarse frente al futuro rey Felipe II, a lo que el caicque q'eqchi' dijo que entre principales no se arrodillan. La estadía duró más de 200 días y lograron hacer varios tratos con los españoles que beneficiarían al pueblo q'eqchi'. Después de esta visita se nombró la tierra de Aj Pop Batz como la tierra de la "verdadera paz": Verapaz.

$$
\text { Guia para mentoras de Abriendo Oportunidades }{ }^{(3)}
$$


Lo que rescatan muchos es que gracias a la inteligencia de $A_{j}$ Pop Batz, se evitó que entraran varios españoles violentos a Tezulutlán. Él ha sido declarado como héroe nacional, pese a que hoy es un héroe olvidado.

- Santa Catarina Ixtahuacán (1743)

- Tecpán (1759)

- Santa María Nebaj (1793)

- Santa María Chiquimula (1802)

- San Juan Chamelco, Alta Verapaz - Manuel Tot (1813)

- Levantamiento de Totonicapán - Atanasio Tzul (1820)

\section{Hagamos algo juntas}

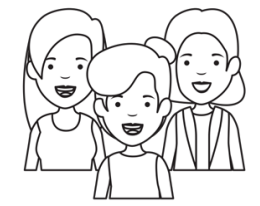

No todas las resistencias se dan de la misma manera, y ahora vamos a pensar en una forma de resistir que tenemos muy a la mano.

Comparte con las niñas las siguientes instrucciones:

1. Vamos a dividirnos en dos grupos.

2. El primer grupo, pensará en nuestra comunidad y en lo que sembramos en ella. Hará una lista, lo más completa posible, de todos los alimentos que podemos encontrar. El segundo grupo, hará memoria sobre los productos artesanales que podemos conseguir fácilmente en la comunidad. Puede ser ropa, utensilios, cualquier cosa que usemos diariamente. Todo eso se anotará en otra lista.

3. Al concluir, nos reuniremos de nuevo y cada grupo nos compartirá los elementos que anotó en su listado. Podemos ir integrando cosas que se nos hayan olvidado.

4. Discutamos: żes posible encontrar formas para que todas podamos tener acceso a los alimentos y productos que mencionamos sin utilizar dinero? Trata de guiar esta conversación mencionando formas creativas y comunitarias para poder realizar el intercambio de bienes.

Al concluir la discusión, reflexiona esto con las niñas:

Durante siglos, nuestros pueblos han resistido de las más distintas formas: desde las rebeliones previas a la independencia, la lucha por recuperar las tierras comunitarias (llegando incluso a comprarlas de vuelta a quienes se las habían despojado), la conservación de la esencia cultural y la construcción de organizaciones propias para encontrar más y mejores oportunidades.

Ahora mismo, nosotras somos parte de una cadena de resistencias, que se mantiene cambiando siempre. Debemos resistir desde lo sencillo, todos los días, en las formas más simples. Las formas en que adquirimos bienes y servicios necesarios para 
nuestra vida diaria pueden ser también un modo de resistir, haciendo que todos en nuestra comunidad aporten e intercambien libremente lo que pueden hacer.

\section{Las palabras que nos nombran}

Hoy vamos a conocer un breve poema del escritor Roberto Obregón, que nos habla de la resistencia y la alegría. Este escritor murió hace 50 años, pero sus palabras nos siguen hablando.

Lee el siguiente texto, de manera clara y pausada.

Es importante que cuando tú, como mentora, realices el estudio de la sesión, tengas en cuenta qué significa este texto para ti, y que lo apuntes. Así podrás tener mayor claridad sobre cómo guiar la discusión con las niñas cuando compartas con ellas el texto:

\section{Las inscripciones \\ (fragmento) \\ Roberto Obregón}

No podemos encender la hoguera

Mojado está el bosque

Podridos están los troncos

No podemos quebrar los colmillos del frío

Arrancar

Y recobrar nuestros huesos entumecidos

En la humedad en el agua

Nos ha tocado prender la hoguera

En la oscuridad en la noche

Nosotros somos la región más espesa

A oscuras sesionamos bajo la helada

$Y$ conferenciamos sobre nuestro quehacer

De cómo allí los muertos continúan

Jugando un gran papel en la guerra

De qué manera se escogen entre todos

Quiénes llevarán a la espalda el mayor peso

En los ratos

De agudo peligro

Acérquense los del fuego

Los enamorados de la vida

Nos calentaremos con estos nuestros corazones

Hechos leña bajo este rudo temporal

Pero contentos

$$
\text { Guia para mentoras de Abriendo } O_{\text {portunidades }}{ }^{\circledR}
$$


Conversen sobre el poema: ¿2Qué les hace sentir? ¿ंCreen que nuestro compañero Manuel Tot pudo haber dicho algo como lo que se dice en el poema?

\section{Oportunidades en casa}

Están a punto de concluir esta sesión. Pídele a las niñas que al nomás llegar a su casa conversen con sus familiares sobre lo que aprendieron hoy. Diles que les pregunten si conocían la historia de Manuel Tot y si conocen algún otro nombre de un líder de la resistencia comunitaria. Si pueden anotar lo que sus familiares les cuenten, sería estupendo, pues lo compartirán al inicio de la próxima sesión. 


\section{Sesión 7}

\section{Independientes, ¿de qué?}

\section{Hagamos memoria}

Recibe con alegría a las niñas para esta séptima sesión. A estas alturas, tú ya no eres únicamente su mentora: ya eres su amiga. Platica con ellas, interésate por lo que les pase y cuéntales qué tal estuvo tu semana.

Recuérdales lo que les pediste hacer en casa al final de la sesión anterior. Diles que te cuenten qué platicaron con sus familiares respecto a las resistencias comunitarias del pasado y del presente. Completa la conversación con alguna información extra que hayas encontrado durante los últimos días.

\section{Nuestras grandes preguntas}

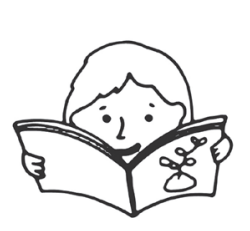

Cuéntales a las niñas que hoy aprenderán algo sobre una fecha que seguramente han escuchado antes: 15 de septiembre de 1821. Pregúntales si saben qué pasó ese día. ¿Qué les han contado en la escuela respecto a la Independencia de Guatemala? Esa es una pregunta importante que Esperanza se hará en el próximo relato.

\section{Los relatos de Esperanza}

Escuchen todas con atención, e imaginen que nos encontramos otra vez con nuestra amiga Esperanza:

\section{La tierra que tejemos}

Septiembre es un mes muy lluvioso. Y aunque la lluvia es buena para

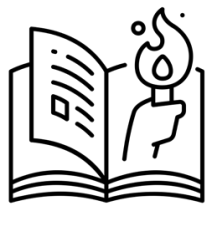
las plantas, refresca el ambiente y alivia el calor, a veces las cosas se complican cuando llueve, porque varias casas de la aldea donde vive Esperanza están al pie de un cerro y corren el riesgo de los deslaves. Los ríos crecen e inundan los campos cercanos. Aunque este año, el río apenas es un riachuelo delgado debido al desvío que hicieron las plantaciones de palma.

Esperanza ha aprendido tanto últimamente que siente que todo, todo lo que la rodea, le cuenta una historia. Ha aprendido a cuestionarse las cosas, a preguntarse qué es verdad y qué no. En la escuela le ha pasado varias veces: todo lo que aprende se convierte en

$$
\text { Guia para mentoras de Abriendo Oportunidades }{ }^{\circledR}
$$


una puerta hacia otras preguntas y muchas veces las respuestas la han dejado pensando mucho.

Este mes, en la escuela se han concentrado mucho en la celebración de la independencia de Guatemala, y su maestra les ha dicho que harán un altar cívico para honrar a la Patria. Esperanza escucha con atención lo que se dice en la clase sobre la independencia. Por eso sabe que antes Guatemala era parte de la corona española, y que fue así durante 300 años. Entonces no era un país, sino una capitanía, y no abarcaba solo el territorio actual, sino todo lo que hoy se conoce como Centroamérica e incluso parte del sur de México. "Qué raro", pensaba Esperanza, "celebramos la separación, celebramos el hecho de habernos hecho más chiquitos".

Su maestra le decía que gracias a los Próceres de la Independencia somos un país LIBRE, SOBERANO e INDEPENDIENTE, y les daba una lista con los nombres de esos próceres, uno tras otro. A decir verdad, a Esperanza no le decían gran cosa esos nombres. Una tarde, decidió consultar un viejo diccionario que estaba siempre en el salón de clase, y se puso a buscar el significado de las tres palabras que su maestra repetía tanto: LIBRE, SOBERANO e INDEPENDIENTE. Encontró lo siguiente:

Libre: Que tiene capacidad para escoger y dirigir su forma de actuar o de pensar. // Que vive en libertad o no está preso o bajo el dominio de otro.

Soberano: Que se gobierna a sí mismo, sin estar sometido políticamente a otro.

Independiente: Que tiene independencia política, que no depende de una autoridad superior.

Eso era Guatemala, según lo que aprendían en la escuela. Y eso era lo que tenían que representar en un altar que la maestra les había pedido a sus alumnas que hicieran. Las ideas que les sugería la maestra para los altares cívicos eran las siguientes: hacer símbolos patrios con papel de china, escribir en un papel con brillantina la Jura la Bandera, o poner un montón de pequeñas banderitas azul y blanco en el altar.

-Hagan algo que las haga sentir orgullosas de ser guatemaltecas -les decía constantemente.

Y a Esperanza había muchas cosas que la hacían sentir orgullosa, pero no precisamente las mismas que decía su maestra, porque cuando ella pensaba de dónde era, cuál era la tierra que amaba, dónde imaginaba cosas buenas, dónde se soñaba y en dónde tenía guardada toda su memoria, pensaba en el cerro que está atrás de su casa, en el río que se habían robado, en la gente de su aldea, en su abuelo que la cuidaba, en las siembras de los patios de cada casa, en la feria en la que vendían sus alimentos, en jugar futbol con sus amigas, en las montañas que veía cuando se iba de viaje con su don Lix, en la neblina que aparecía como si fuera un fantasma gigante entre los árboles. ¿Eso es Guatemala? ¿Eso era estar orgullosa de ser guatemalteca?

Esa noche, Esperanza se quedó dorimada pensando en eso. Y cuando abrió los ojos del lado de los sueños vio un lugar que se parecía a su aldea, pero estaba un poco cambiado. Vio gente que conocía-Quetzalí, su Tata Lix, sus amigas-, pero también vio otras personas que no había visto nunca, pero que la saludaban amistosamente.

-Ch'ona' -le decían unas niñas.

-Ch'owa' -le dijo un hombre que no había visto nunca pero que se le hacía conocido.

Y ella les contestaba feliz, como si todos fueran sus familiares, como si estuviera 
llegando a una fiesta.

-Sa'ch'o -les decía contenta.

Se dio cuenta que todos estaban trabajando en algo pero no entendía muy bien en qué. De pronto, como pasa en los sueños, ella estaba trabajando también: tenía hilos en sus manos, todos tenían hilos: todos estaban tejiendo juntos. Vio que a lo lejos otras gentes extendían un inmenso tejido y lo ponían encima de las montañas. Y el río estaba grande -como antes- y todos hacían cosas diferentes pero no dejaban de tejer. Era hermoso ver las montañas cubiertas de tejido, y al pasar el río que el agua hablaba con voz de anciana y le decía:

-Mirame, nena Esperanza. Yo estoy contenta cuando me sueltan y puedo ir de adentro de la tierra al mar, para que la vida siga.

Y Esperanza se despertó, todavía con los colores en los ojos y las voces en la cabeza.

Cuando llegó a la escuela, les dijo a sus amigas que tenía una idea perfecta para su altar. Las niñas se pusieron muy contentas y escucharon con atención el sueño de Esperanza. Les gustó la idea de representar una tierra con sus tejidos. Durante algunos días planearon cómo hacerlo y al final decidieron usar sus propios cortes, los más hermosos y coloridos. Hicieron unas armazones con pequeños chiriviscos que recogieron cerca de la escuela, y al poner los cortes encima todo se veía como un paisaje de montañas cubiertas de tejido, exactamente como las que había soñado Esperanza. Pusieron agua y frutas, verduras y hierbas de sus huertos y sus patios. Y con otras ramas pequeñas hicieron letras para poner el título de su altar: LA TIERRA QUE TEJEMOS, se leía de lejos.

Sin duda su maestra no se esperaba ese altar, porque cuando lo vió se quedó en silencio y sus ojos se llenaron de lágrimas. Era tan lindo que no parecía un altar: era un sueño, pero no solo un sueño; era un deseo; pero más que eso, era un plan para el futuro. Era perfecto.

Muy contenta, la maestra se entusiasmó y le dijo a las niñas:

- Vamos a arreglar todo lo necesario para que lo repitan allá en Cobán. En unos días va a haber un concurso de altares cívicos, y yo creo que ustedes pueden ganar.

Unos días después, la maestra y las niñas estaban en la Gobernación de Cobán, muy contentas, presentando su altar. Había muchos altares, hechos por niños y niñas que usaban diferentes uniformes y que venían de distintos municipios. Ahí, Esperanza vio a Patricia, la nieta de doña Cora, la señora del comedor. Le sorprendió verla vestida con corte y huipil, y con los ojos y la boca pintada. En su altar había fotos de paisajes con cataratas, pozas, bosques nubosos, fotos de quetzales y monjas blancas y, de hecho, aparecía también el río que les habían robado las plantaciones.

-Hola, Espe -dijo emocionada Patricia-. ¿Qué tal estás? ¿Qué andás haciendo por aquí?

Y Esperanza le iba a contestar, pero de nuevo parecía que le preguntaba cosas sin esperar su respuesta, sobre todo cuando estaba con sus amigas, porque en realidad cuando estaban solas era más atenta.

-Este es nuestro altar. Mirá que lindo. Es que Guatemala es tan linda, ¿̇verdad? -dijo sonriente Patricia. ¿YY tú veniste por tu altar también?

-Sí -le dijo Esperanza-, se llama La tierra que tejemos.

Patricia no le puso mucha atención, se quedó viendo hacia su huipil y la interrumpió:

$$
\text { Guia para mentoras de Abriendo Oportunidades }{ }^{\circledR}
$$


-Ah, y mirá: ahora estamos vestidas igual, porque en septiembre nosotras también nos ponemos ropa típica.

En verdad Esperanza no tenía idea de qué quería decir Patricia con ropa típica. En su mente, trataba de organizar las ideas: "Somos independientes, somos libres, somos soberanos. Pero no todos somos siempre iguales: solo hoy, porque Patricia se vistió como yo me visto todos los días. Pero no somos libres porque no podemos decidir sobre nuestra tierra y la gente trabaja mucho por muy poco dinero, y todo cuesta mucho, y hay gente que decide cosas que a nosotras nos afectan... Los libres son ellos, no nosotros", pensaba Esperanza, "pero si ellos son Guatemala y nosotros también, ¿̇por qué hay gentes que pueden hacer lo que quieran con sus siembras y con nuestra agua? ¿Por qué nosotros no podemos decidir qué hacer con nuestros recursos? Tal vez esos próceres de la independencia realmente no pensaron en todos, sólo en los que eran como ellos".

Así se le pasó la tarde a Esperanza, pensando mientras veía todos los altares del departamento. A eso del mediodía fue la premiación. El concurso lo ganó el colegio de Patricia, y Esperanza y sus amigas quedaron en segundo lugar. Los miembros del jurado dijeron que les faltaban banderas de Guatemala, que no estaban los símbolos patrios, pero que estaba muy lindo y que era muy original.

En silencio, Esperanza sabía que sus tejidos, que sus montañas, que la comida que sembraban, eran sus verdaderos símbolos: eran su soberanía, su libertad, su independencia; y eso le bastaba para sentirse feliz. Almorzaron kaq'ik juntas y les dieron una medalla y 20 quetzales a cada una de las niñas.

Recogieron todo por la tarde, y salieron a esperar el bus que las llevaría de vuelta a su comunidad. En eso estaban, cuando Esperanza le puso atención al billete azul que le habían dado como premio por su altar. Enfrente, aparecía la cara de un hombre con peinado raro y debajo decía: "Doctor Mariano Gálvez, Prócer de la Independencia". Esperanza le dio la vuelta, y atrás se veía una escena con hombres de vestimenta extraña, hombres que no se le hacían familiares, en un salón bastante lujoso. Debajo de la escena decía: "Firma de la Independencia de Guatemala". Aunque no era la primera vez que veía un billete como ese, era la primera vez que ponía atención a sus detalles.

Ya sentada en el bus y mientras veía el paisaje, Esperanza pensaba en las montañas y en toda la vida que llevaban encima. Recordó entonces los tejidos que las cubrían en su sueño y en su altar, y pensó: "No, la independencia no es eso que sale en el billete, la independencia es por la que vamos a trabajar siempre, la que estamos buscando, la que va a ser. Quién quita", pensaba Esperanza, " y algún día hagamos otro país, tan grande que ya ni siquiera se llame país, que incluya a Honduras, México y El Salvador. Seguro le pondríamos otro nombre..."

Durante el camino a casa, hasta se imaginó con sus amigas en la parte de atrás de un billete del futuro. Pero no: los billetes y el dinero mejor ya no existirían en el futuro. Tampoco existirían los países: sólo estará la Vida abrazándonos, y nosotros la cuidaremos.

¿Qué piensas tú, como mentora, de este cuento? Pregúntatelo y reflexiona con las niñas.¿̇Ya le habían puesto atención a las figuras que aparecen en el billete de Q20? 


\section{Recuerda tener claro que:}

1. El Acta de Independencia de Centroamérica se firmó el 15 de Septiembre de 1821, en la Ciudad de Guatemala. Por medio de ella, todas las provincias centroamericanas dejaron de depender políticamente de la corona española, y entonces empezaron a fundarse los actuales países de la región. Casi todos los que firmaron esa acta eran de familias poderosas, y se beneficiaron al máximo con ella. Algo que llama la atención es que el último capitán general de la época colonial fue el primer jefe político de la Provincia de Guatemala: su nombre es Gabino Gaínza. Otros países de América tuvieron una independencia violenta, mientras que en Guatemala ésta fue negociada por hombres blancos para manejar mejor el cambio de poder.

2. Cuando se dio la independencia, España dejó de tener el control absoluto, pero ese poder no se distribuyó equitativamente entre las sociedades "libres, soberanas e independientes". La realidad política y sobre todo económica de estos territorios siempre estuvo ligada a otra potencia colonial: en algún momento fue Inglaterra, luego Alemania y Estados Unidos. La economía de Guatemala se especializó en la exportación de materias primas agrícolas, y la producción se dio sobre territorios despojados y con el trabajo gratuito y forzoso de buena parte de la población. La independencia política de España no alteró esas circunstancias.

\section{Hagamos algo juntas}

Para esta actividad, es necesario que todas puedan apreciar muy

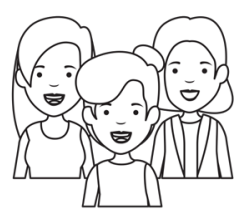
claramente ambos lados de un billete de Q20. Puedes encontrar una imagen en internet y proyectarla al frente de todas; o bien, puedes imprimir esa imagen en una hoja individual para cada niña. Recuerda: es importante que estén los dos lados del billete, para que todas puedan ver lo que Esperanza vio con su premio.

Pídeles que pongan atención a los detalles y coméntenlo juntas. ¿ Cómo se ven las personas que aparecen retratadas en el billete? ¿Qué impresión nos dan?

Explícales brevemente en qué consistió la firma del Acta de la Independencia, y cuéntales que a continuación les leerás un pequeño fragmento con que inicia dicha acta:

"1-_ Que siendo la independencia del Gobierno Español la voluntad general del pueblo de Guatemala, y sin periuicio de lo que determine sobre ella el Congreso que debe formarse, el Sr. Jefe Político la mande publicar para prevenir las consecuencias, que serían temibles en el caso de que la proclamase de hecho el mismo pueblo".

$$
\text { Giva para mentoras de Abriendo } O_{\text {portunidades }}{ }^{\circledR}
$$


Discutan a partir de las siguientes preguntas:

- ¿̇Qué quiere decir este pasaje?

- ¿̇A qué consecuencias se referirán?

- Ahora, a 200 años de distancia, es interesante pensar qué relación hay entre esa independencia y nosotras. Piénsalo y discútelo con las niñas.

Toma en consideración lo que te recordamos líneas arriba, justo al terminar el relato de Esperanza. Platica con tus compañeras mentoras y juntas fórmense una idea de lo que la independencia significa para nuestras comunidades hoy. ¿̇Conocían ya este pasaje del Acta de Independencia?

\section{Oportunidades en casa}

Teniendo en cuenta lo que hemos platicado en esta sesión, pídeles a las

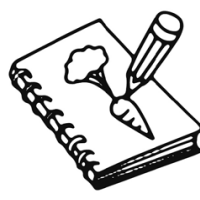
niñas que dialoguen en casa y que traten de responder junto a su familia las siguientes preguntas:

- ¿Qué es Guatemala?

- ¿Qué es ser guatemaltecos?

\section{Ruta hacia un proyecto comunitario}

Antes de concluir la sesión, recuérdale a las niñas que estamos a punto de llegar a la mitad de este proceso de aprendizaje, y que el proyecto comunitario no se nos debe olvidar. Recuérdales las decisiones que han tomado en las sesiones previas $y$, para ir avanzando, organiza con ellas un cronograma de las actividades que deberán realizar para concretar su proyecto juntas. Puedes escribirlo en un papelógrafo, donde sea visible durante las sesiones por venir. En él podrán ir registrando avances y llevarán un mejor control de lo que cada una realiza.

El cronograma puede ser un cuadro con los siguientes datos:

\begin{tabular}{|l|l|l|l|}
\hline Actividad & Responsable & Fecha prevista & Estado de cumplimiento \\
\hline & & & \\
\hline & & & \\
\hline & & & \\
\hline
\end{tabular}


Cada una de las niñas debe tener claro cuál es su compromiso y su responsabilidad concreta con el proyecto.

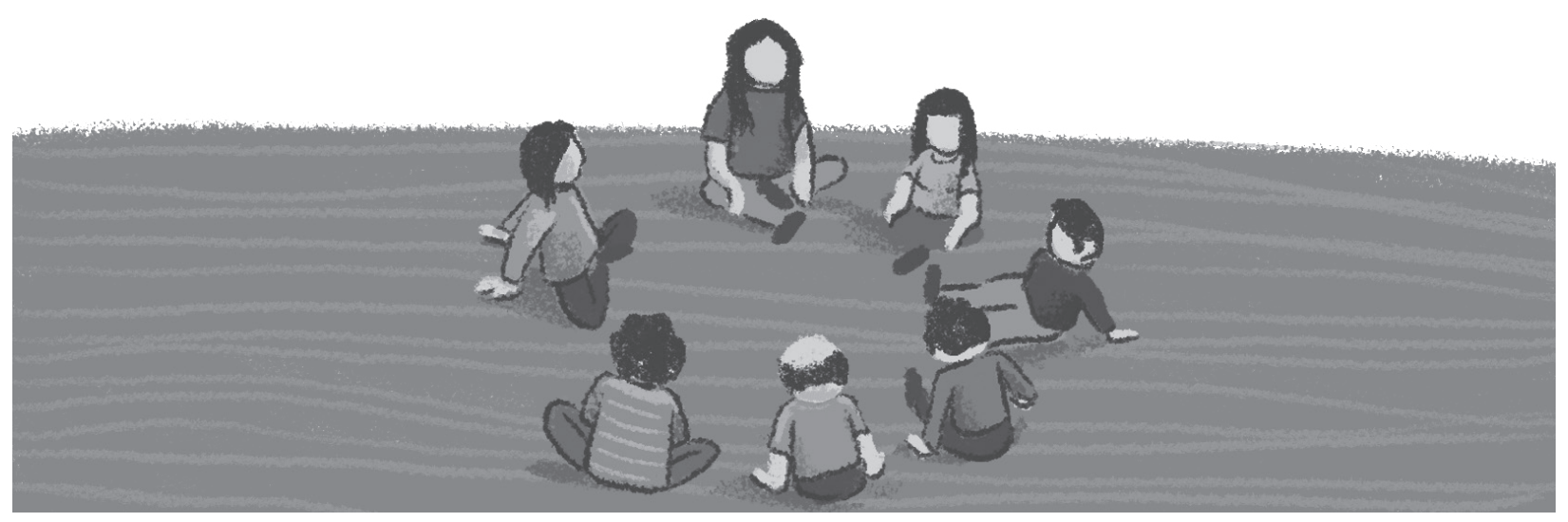




\section{Sesión 8}

\section{¿Quiénes inventan los países?}

\section{Hagamos memoria}

Sean bienvenidas a esta octava sesión. Mientras las niñas llegan y el grupo se reúne, platica con ellas sobre las cosas buenas que te pasaron en la semana. Luego, recuerden juntas los contenidos que vieron en la sesión anterior, que tenían que ver con la Independencia. ¿Aún recuerdan lo que le pasó a nuestra amiga Esperanza?

\section{Nuestras grandes preguntas}

Comparte con las niñas que hoy aprenderemos juntas sobre los países.

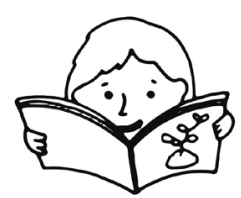
Debes tener clara la siguiente definición:

Un país es un territorio, un conjunto de leyes y una población que conforman una unidad política. En ese sentido, los países no son fijos, no son parte de la naturaleza: son creaciones, invenciones, formas que adoptamos para la vida social.

Tomando esto en consideración, platica con las niñas sobre el país al que pertenecen. ¿Cómo se llama? ¿̇Qué saben de él?

Como nacimos en Guatemala, se nos dice que somos guatemaltecas. ¿2Qué significa esto? Es necesario que comprendas la definición de otro concepto: la identidad.

La identidad es un conjunto de rasgos compartidos, que nos definen frente a los demás. Estos rasgos se van formando con el tiempo, y por eso tienen que ver con la historia.

¿Creen ustedes que entre un señor de Zacapa, una niña de Chisec, una joven de Quetzaltenango y un adulto de la Ciudad de Guatemala hay una identidad compartida? Reflexionen juntas.

\section{Los relatos de Esperanza}

Esperanza, sus amigas y su mentora no dejan de aprender juntas. Escuchemos con atención el relato sobre una tarde en la que descubrieron que nuestro país no ha sido siempre igual: 


\section{Una tierra de sueño}

Una tarde, después de ir a la escuela, Esperanza se juntó con algunas de

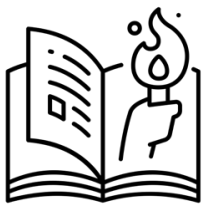
sus amigas. Juntas, han decidido formar un equipo de futbol. Lo hicieron porque no podían jugar en los equipos con niños -cosa que Esperanza no termina de entender, es algo que le incomoda y quiere cambiarlo-, y no se iban a quedar con las ganas de patear la pelota. Encontraron un pequeño campo que nadie usa y ahí, por las tardes, se dedican a entrenar un rato, a correr, a hacer tiros y sobre todo a pasársela bien.

El jueves pasado, después de jugar fut, Esperanza iba caminando con sus amigas Gloria, Maribel y Margarita, cuando a lo lejos vieron a Quetzalí. Corrieron para alcanzarla, pues la querían saludar y contarle que estaban armando su equipo de futbol. Quetzalí iba con una mochila, porque estaba estudiando en la universidad y a cada cierto tiempo debía ir al internet a investigar.

-iQuetzalí!, mire lo que se nos ocurrió, ivamos a hacer un equipo de fut! -le dijo Esperanza, muy contenta.

Las niñas empezaron a contarle todo desde antes de alcanzarla. Quetzalí se sintió feliz de verlas con sus brazos levantados corriendo hacia ella.

-Qué alegre que hagan su equipo -les dijo Quetzalí-, no hay que creerse eso de que el futbol es cosa de hombres. Jugar con la pelota es cosa de todos y, es más, deberían hacer equipos mixtos, porque yo ya vi que ahí serían imparables.

Las niñas le preguntaron qué estaba haciendo, y cuando ella les dijo que iba al internet, todas insistieron en que la querían acompañarla. Aunque ella tenía que trabajar en su investigación de la $U$, no quiso decirles que no. Durante el camino, todas la llenaron de preguntas: sobre sus tareas, sobre su carrera, sobre el huerto que estaba empezando a hacer en el patio de su casa... No querían quedarse con ninguna duda: si tenía algún equipo favorito de futbol, si tenía novio...

Quetzalí contestaba a todo, pero en el fondo seguía pensando en su trabajo. Al llegar al internet, se sentó frente una computadora y las niñas la rodearon. Abrió el buscador de Google y escribió "Fundación de la República de Guatemala". Las niñas se fueron quedando calladas cuando vieron todo lo que aparecía en la pantalla de la computadora. Imágenes antiguas, un señor de bigote con uniforme, y unos mapas viejos que, a decir verdad, no se les hacían para nada familiares.

- ¿̇Y eso en dónde es, Quetzalí? -preguntó Maribel.

-Eso es Guatemala -respondió su mentora.

-iUy! Qué raro. ¿̇Por qué se ve así? ¿̇Estaba en otro lugar o qué?

Quetzalí se rió y les dijo que no, que lo que pasaba es que la forma que tenía ahora el país no había sido siempre así.

- ¿̇ Los países cambian de forma? -preguntó Esperanza sorprendida.

Y Quetzalí les explicó que los países no son siempre iguales, que incluso antes no existían países como ahora los conocemos, sino que habían territorios con culturas diferentes, con grupos de personas que se organizaban en los mismos lugares, hablaban los mismos idiomas y tenían una vida similar.

$$
\text { Giva para mentoras de Abriendo } O_{\text {portunidades }}{ }^{\circledR}
$$


-Recuerden -les dijo Quetzalí- que cuando los españoles vinieron, todas nuestras tierras fueron parte de España.

Las niñas se rieron mucho con esto último.

-Ya viste, vos -le dijo Gloria a Margarita- antes nosotras éramos españolas. iJajaja!

-Pero si España está del otro lado del mundo -decía Esperanza.

No era fácil explicar esas cosas. En realidad, Quetzalí se sentía hasta un poco nerviosa, pero les explicó que así funciona el poder: cuando las cosas se toman por la fuerza, como pasó con nuestras tierras, pasan a dueños que en realidad no tienen que estar en los lugares y que sólo se benefician de sus riquezas. Además, que para poseerlas deben hacerlo a través de la violencia.

Quetzalísiguió buscando información, y las niñas seguían atentas todos sus movimientos. Así, fueron aprendiendo juntas algunos detalles sobre la fundación de Guatemala. Era maravilloso ver la cantidad de formas distintas que tuvo el mapa. Quetzalí les iba contando que en los 50 años que siguieron a la Independencia, Guatemala pasó por muchas cosas: formó parte del imperio Mexicano -cosa que también le dio mucha gracia a las niñas-, luego se convirtió en una de las Provincias Unidas de Centro América, y finalmente (el 21 de marzo de 1847, 26 años después de la firma de Independencia, un señor llamado Rafael Carrera fundó la actual república de Guatemala.

- ¿̇e dan cuenta que el mapa se ha ido haciendo cada vez más chiquito? -dijo Margarita.

-Sí -respondió Quetzalí. Y recuerden todos los nombres que ha tenido: Capitanía General, Reino, Federación...

-Yo le hubiera puesto un nombre más bonito -dijo Gloria con una sonrisa.

- ¿Cómo le pondrían ustedes a su país? -le preguntó Quetzalí.

-Mmm... Yo le pondría Tierra Húmeda -dijo Gloria después de pensarlo un pcoo.

-iYo le pondría Matk'!, Lugar de Sueño o algo así -dijo Esperanza.

Queztalí debía seguir avanzando en su trabajo, y ya no le quedaba mucho dinero para seguir en el internet. Por eso, se trató de apurarse. En las páginas que consultaba las niñas se enteraron de que, durante esos años existieron dos bandos: unos se llamaban Conservadores y otros Liberales. Los primeros querían mantener las cosas como estaban en la época colonial, y los segundos decían que querían cambiarlo. Entonces empezaron las guerras, y mucha gente murió peleando. Las fronteras entre las provincias centroamericanas se fueron fijando, y cada país -ahora sí podía hablarse de países- fue tomando su propio rumbo.

Quetzalí se quedó pensativa. Luego de un momento, les dijo:

- ¿̇Se dan cuenta que cada frontera, cada una de esas líneas que separa los países cuenta la historia de una guerra?

-Yo ya no quiero que hayan países -dijo Esperanza.

- ¿Por qué?

-Porque siento que la vida es una. Miren a los pájaros: ellos no saben de países. Tampoco los ríos, ni las montañas. Pero la gente dice "Esto es mío" y hace su raya en la tierra. Y los pájaritos pasan de un árbol a otro sin saber que van de un país a otro. Mejor que no haya países, y que el mapa sea solo la tierra sobre el agua. Así no estaría cambiando a cada rato. 
Al escuchar las reflexiones de Esperanza, las niñas sonrieron. Y cuando se acabó el tiempo, todas salieron de vuelta a casa.

Quetzalí hizo su ensayo para la universidad, y esas palabras de Esperanza fueron muy importantes para escribirlo, porque era cierto: hay cosas que creemos que son leyes de la vida, y en realidad no lo son. Los países, por ejemplo, son inventos de la gente, y muchas veces sólo le convienen a los poderosos. Durante días, la mentora se quedó pensando en que deberíamos recuperar la libertad que otros se han tenido para nombrar el mundo, y que para hacer que la vida sea más buena para todos, hay que empezar por imaginarla.

Pregúntale a las niñas qué piensan luego de escuchar el relato.

\section{Recuerda tener claro que:}

1. Las fronteras de un país se deciden, la mayoría de las veces por la fuerza. Por eso, esas fronteras cambian a lo largo de la historia.

2. Recuerda que la Independencia de Centroamérica se firmó en 1821. Desde entonces, los bandos conservadores y liberales se disputaron el poder político, pero sobre todo económico. Los primeros dependían de la grana (un colorante natural que se vendía muy bien en Europa), mientras que los segundos empezaron a sembrar y exportar café. Así adquirieron poder y le dieron forma al país que recién empezaba.

3. Como tal, la república de Guatemala se fundó hasta 1847 por decisión de Rafael Carrera, luego de muchas guerras, conflictos y negociaciones. Desde entonces, se define como una república libre, soberana e independiente, a pesar de que nunca ha sido lo suficientemente libre en lo político, ni independiente en lo económico.

4. Con el tiempo, la recién fundada república fue cambiando. Los liberales tomaron el poder y establecieron leyes que afectaron profundamente la situación (y que hoy día siguen afectándonos).

5. Quienes toman las decisiones, lo hacen pensando -la mayoría de las veces- en su beneficio personal. Por eso, hoy tenemos un país que no da las mejores oportunidades para todos.

\section{Hagamos algo juntas}

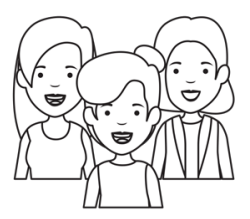

Durante la sesión de hoy, hemos hablado de países, fronteras y mapas. Por eso, para esta actividad, deberás preparar en un papelógrafo un mapa actual de la república de Guatemala. Preséntaselo a las niñas y pregúntales si lo reconocen. ¿̇Les dice algo la figura del mapa del país?

En un segundo momento, ubica el territorio de Alta Verapaz sobre ese mapa. Puedes dibujarlo frente a las niñas, o llevar otro papelógrafo preparado, donde se ubique el departamento ya dentro del mapa del país.

$$
\text { Guia para mentoras de Abriendo Oportunidades }{ }^{(3)}
$$


En un tercer momento, coloca un punto para identificar el municipio de Chisec. Toda esa información podrás encontrarla fácilmente en internet.

Pregúntale a las niñas qué sienten al identificar sobre el mapa el lugar que habitan. ¿Qué sensación les provoca ir pensando en territorios más pequeños? Platiquen sobre la experiencia que resulta de identificar el lugar donde vivimos en un mapa dibujado.

Sería bueno recordar el relato de la primera sesión, cuando los primeros grupos humanos poblaron el continente. ¿̇Creen que ahí habían países? No. Déjales claro a las niñas que la vida no tiene fronteras. Discutan cómo sería un mundo sin países.

\section{Las palabras que nos nombran}

Como hemos visto, la historia -el tiempo- significa cambios. En este pasaje escrito por Miguel Ángel Asturias, el escritor más reconocido de Guatemala, podremos ver cómo las distintas épocas van cubriendo a otras, como si fueran capas de una cebolla. ¿̇Las han visto? Leamos con atención:

\section{Leyendas de Guatemala (fragmento) Miguel Ángel Asturias}

El Cuco de los Sueños hace ver una ciudad muy grande -pensamiento claro que todos llevamos dentro-, cien veces más grande que esta ciudad de casas pintaditas en medio de la Rosca de San Blas. Es una ciudad formada de ciudades enterradas, superpuestas, como los pisos de una casa de altos. Piso sobre piso. Ciudad sobre ciudad. ilibro de estampas viejas, empastado en piedra con páginas de oro de Indias, de pergaminos españoles y de papel republicano!

Explícales que la Rosca de San Blas es una cadena de montañas que rodea la Ciudad de Guatemala. Pídeles que se fijen en cómo las ciudades más antiguas quedan debajo de las más nuevas.

\section{Oportunidades en casa}

Antes de terminar la sesión, dales las siguientes instrucciones para la actividad que realizarán en casa durante la semana:

1. Tendrán que inventar un país. ¿Cuál será su nombre? Piénsenlo y anótenlo en una hoja de papel.

2. En esa hoja, dibujen el mapa de su país. Coloquen todo lo que debería tener, definan dónde estarán sus fronteras. 
3. Al inicio de la próxima sesión, presentaremos nuestros países imaginarios a nuestras compañeras. 


\section{Sesión 9}

\section{Las consecuencias no se acaban}

Estamos justo a la mitad de este recorrido con Esperanza por la historia de nuestros territorios y nuestros pueblos. ¿Cómo lo han sentido? Reflexiona esto antes de iniciar la sesión, y pregúntales a las niñas qué opinan. Es importante que entre todas valoren el proceso y se expresen libremente.

\section{Hagamos memoria}

Invítalas a hacer memoria: ¿̇ecuerdan que durante la semana cada una debía inventar un país? Pues lo primero que haremos será conocer esos países que inventamos. Dales las siguientes instrucciones:

1. Pídeles que se reúnan en parejas.

2. Durante 5 minutos le contarán brevemente a su compañera cómo se llama y cómo es el país que inventaron. Podrán mostrarse los dibujos que hayan hecho y contarse la mayor cantidad posible de detalles.

3. Cuando todas hayan compartido con su compañera el país de su imaginación, reúnanse en grupo y compartan su experiencia personal al realizar este ejercicio durante la semana.

\section{Nuestras grandes preguntas}

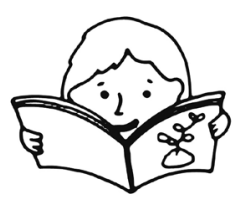

Recuérdales a las niñas que la semana anterior escucharon hablar de dos grupos políticos del pasado en Guatemala: los conservadores y los liberales. Pudimos ver cómo a través de guerras, estos grupos se arrebataron el poder entre sí para imponer sus decisiones y sus intereses.

Hoy, entonces, junto a Esperanza nos preguntaremos qué es una revolución.

Comparte con las niñas este concepto:

Una revolución es un cambio profundo, y generalmente violento, en las estructuras políticas y económicas de una sociedad. A veces, cuando los pueblos participan en ellas, esos cambios pueden ayudarles a mejorar sus condiciones de vida. Pero cuando eso no sucede, las cosas pueden empeorar.

Pregúntales si habían escuchado antes esa palabra, y reflexionen sobre estas preguntas: 
- ¿Qué pasa cuando uno impone su voluntad de manera violenta a otro?

- ¿́La violencia es un medio adecuado para tratar con los demás?

\section{Los relatos de Esperanza}

A cada momento de la vida podemos aprender detalles sobre el pasado, sobre la historia de nuestra comunidad. Si ponemos atención, cada cosa de nuestro entorno no ayuda a explicarnos por qué estamos como estamos. Eso le pasó un día a Esperanza. Escuchemos con atención este relato:

\section{Las consecuencias no se acaban}

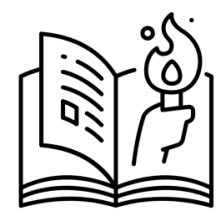

Esperanza se prepara nuevamente para ir a Cobán. Su Tata Lix necesita que lo acompañe, pues durante las últimas semanas ha estado trabajando en más cajitas de madera y debe ir a entregarlas. Esta vez son unas cajas especiales para guardar café.

Otra vez es de madrugada, y otra vez deben atravesar la laguna que se formó el año pasado por las tormentas. Han pasado meses y ahí siguen las casas hundidas: las que eran tierras para vivir ahora son lugar donde reposa el agua. Esperanza se pregunta en dónde estará viviendo toda esa gente cuyas casas ahora se llenan de musgo y de animalitos que nadan.

Siempre que van a Cobán se cansan, pero a Esperanza el viaje la entretiene bastante. Aprovechan a pasar haciendo más mandados, van a ver a la organización que los ayuda con los asuntos legales para recuperar el río. "Qué loco es el mundo", piensa Esperanza, "se robaron nuestra agua y no podemos hacer nada, y a otra gente todo se los quitó la tormenta la tormenta y tampoco pueden hacer nada".

Durmió durante buena parte del viaje, y cuando se dio cuenta ya era hora de bajar del bus cerca del parque de Cobán. De nuevo fueron al comedor de doña Cora, al mercado y, por último -porque había una hora específica para llegar- pasaron al lugar del café. Cuando llegaron costó mucho que los atendieran. Los dos estaban cansados y con la espalda adolorida porque habían cargado las cajitas durante toda la mañana, y nadie les abría. Esperanza siempre siente que en Cobán hacen con su abuelo cosas que nadie hace en su aldea: tratarlo mal, hablarle como que no estuviera ahí, dejarlo esperando.

Finalmente, luego de tocar varias veces el timbre, salió una mujer.

-¿ंQué necesita?

-Buenas... Vengo a dejarle su encargo a doña Odette.

-Doña Odette no nos dijo que estuviera esperando ningún encargo -respondió la mujer.

-Viera Seño que es un encargo de cajas para guardar el café.

-Pero ella no nos avisó y así no lo puedo dejar pasar.

$-\dot{\imath} Y$ si le dejo a usted el encargo? 
-No me puedo hacer responsable. Los señores son muy delicados con los temas de seguridad, y no podemos abrir la puerta sin que nos digan.

Al escuchar la conversación, Esperanza sintió otra vez eso que le ardía cuando trataban mal a su abuelo. Como un fueguito que le nacía en el pecho y que ojalá la gente pudiera notar.

-Fíjese Seño que venimos de lejos -insistió don Lix-. Doña Odette sabe, ya habíamos quedado, y nos costó mucho el camino. Además, acordamos que al venir me daba mi pago por este encargo.

La señorita de la casa estaba a punto de responder rotundamente que no, cuando llegó una camioneta enorme a bocinar frente al inmenso portón de la par. Era doña Odette, que bajó el vidrio trasero de la camioneta para saludar a don Lix.

-Qué tal, Andrés. Qué bueno que no me quedaste mal. Dejalo pasar, por favor Norma.

El portón se abrió para dar paso a la camioneta, y detrás de ella entraron Esperanza y su abuelo, que se veían diminutos atravesando esa puerta tan grande que era como para gigantes.

Pasaron a una sala que estaba rodeada de flores. Afuera, la grama parecía una alfombra, se escuchaba el sonido de la regadera eléctrica que daba vueltas y los pájaros que iban de un árbol enorme a otro. "Qué grande es todo aquí", pensó Esperanza. Aunque Cobán siempre la hacía sentir distinta, esta vez había superado esa sensación. Todo era aún más diferente. "Hasta Patricia se sentiría rara aquí, pensó.

La señora Odette era ya una mujer mayor. Tenía el pelo amarillo, los ojos azules y la piel muy blanca y arrugada. En realidad, fue amable con su abuelo. Lo recibió con una sonrisa. Las cajas que él le trabajaba iban a probarse para una forma más exclusiva de vender el café y el cardamomo, que tenía un nombre tan raro que Esperanza no podía ni repetirlo. Era el apellido de doña Odette.

En la sala habían unos bustos tallados en madera, fotos de grandes plantaciones de café, retratos pintados, fotos viejas, gente firmando papeles. Unos reconocimientos muy elegantes, en otros idiomas. "The best coffe in the world", "Deustche tradition in Guatemala". Y al centro, unas letras de madera dibujaban la marca del café, que incluía unos volcanes y abajo se leía: "De las montañas de Guatemala".

Frente al gran escritorio de doña Odette, su abuelo recibió unos billetes como pago. Él tenía la costumbre de ordenarlos por valor. Por eso, en lo que hablaba con la señora, le pidió a Esperanza que se los ordenara. Eso estaba haciendo la niña cuando se dio cuenta de un detalle: los señores de los billetes eran unos de los que estaban pintados en los retratos de la sala de doña Odette: Justo Rufino Barrios y Miguel García Granados.

Cuando salieron, Esperanza le hizo un montón de preguntas a su abuelo: ¿̇Por qué esa gente tiene tanto dinero? ¿Por qué si tienen tanto no le pagan más? ¿̇Cómo conoció a doña Odette? Y, sobre todo, żqué están haciendo los señores de los billetes en la sala de esa señora?

-Ay criatura -dijo riendo Tata Lix-, cuánta pregunta que te sale a vos en un ratito. Para responder tendría que contarte toda mi vida, la de mi papá y la de mi abuelo... Estas gentes son muy poderosas, son dueños de las Verapaces... Bueno, una parte es de ellos, otra de los palmeros y otra los mineros... Doña Odette es familiar de los alemanes que vinieron a estas tierras hace mucho. Resulta que esos señores que aparecen en los billetes 
les regalaron estas tierras.

Esperanza casi dio un grito:

-i¿Cómo así que se las regalaron?!

-Pues sí, mija. Este señor de apellido Barrios quería que Guatemala se hiciera productora de café, pero es que hay gentes que creen que sólo lo extranjero es bueno, y por eso los invitó a venir y les regaló todo lo que pudo, incluyendo la tierra y el trabajo de la gente. Lo peor es que creen que nosotros vivimos sólo para atender a los de afuera.

Don Lix se quedó pensando, y luego de un rato continuó:

-Vieras: mi abuelito todo lo que me contaba de cuando vinieron los alemanes. Los pusieron a trabajar a la fuerza por casi nada de dinero, y todas las familias de la comunidad vivían en una situación miserable. Estaban obligados a trabajar para hacer crecer las fincas. Por eso hay tanta gente alemana en esta tierra, hasta vinieron a hacer unas sus casas que les recordaban las de su país... Si a Guatemala la han malbaratado que es gusto, mija, y lo peor es que este señor hizo eso hace mucho. Todo eso empezó en el año 1871, pero las consecuencias, mija, las consecuencias no se acaban. Mirá cómo cuesta todo... Y no vas a creer esto: con los años, a lo que hizo este señor Barrios le llamaron Revolución... Imaginate, hay que tener coraje para decirle a las cosas todo lo contrario a lo que son. Hasta un gran pedazo del país le regaló a México este señor.

Esperanza no creía lo que escuchaba en las palabras de su abuelo:

-Pero Tata Lix, ¿̇y eso no lo podemos cambiar? ¿̇No será que se puede arreglar de algún modo?

-Modos hay, mija, pero llevan tiempo. Y mirá que después de eso vinieron más luchas, más presidentes mandones. Ya hasta hubo una Revolución de verdad. Mi papá, tu bisabuelo, fue de los que trabajaron para que la tierra fuera de la gente, pero como que la gente más poderosa no sólo quiere tener cosas, sino quiere hacer sufrir a los demás.

- ¿̇Pero si toda esa gente nos ha hecho daño, por qué trabajaste para doña Odette? -preguntó confundida Esperanza.

-A ella la conozco desde siempre. Mi mamá trabajó para la mamá de ella, y pues tengo necesidad, mija. Vos sabés que no hay de dónde sacar más. Ella no es mala gente, aunque lo que me pagó a mí no se acerca en nada a lo que va a ganar ella con el café que venda en mis cajas. Pero por eso hay qué pensar la forma de proteger lo poco que tenemos y también de ir recuperando lo que por siglos hemos perdido.

Mientras esperaban el bus de regreso a su comunidad, Esperanza llegó a una conclusión: las gentes que salen en los billetes son los que hicieron que costara tanto tener dinero. Extraño, ¿̇verdad? Pero así era. "Ojalá que no hubiera dinero", pensaba la niña, "ojalá no tuviéramos que comprar nada, ojalá un día podamos hacer que la tierra no tenga dueño, para cuidarla, para quererla, para no verla sufrir".

En la noche, antes de dormir, Esperanza fue a regar su pequeño huerto. "Por lo menos", pensó, "aquí hago crecer comida que no debo comprarle a nadie, y si me falta algo para cocinar se lo hago cambio a Margarita o a Maribel. Algún día así va a hacer toda la gente y ya no vamos a tener que usar dinero, ni verle la cara esas gentes que regalaron nuestra tierra y nos dejó tan fregados".

$$
\text { Evia para mentoras de Abriendo } O_{\text {portunidades }}{ }^{(2}
$$


Es increíble como decisiones que tomó alguien muy lejano hace muchísimos años todavía afectan directamente nuestras vidas. Por eso, siempre es bueno preguntarnos ża quiénes afectarán nuestras decisiones? Platica con las niñas sobre el contenido del relato.

\section{Recuerda tener claro que:}

1. El movimiento liberal de 1871 -que algunos llaman Reforma y otros llaman Revoluciónfue liderado por Justo Rufino Barrios y Miguel García Granados. Ellos le quitaron el poder por la fuerza de las armas a los conservadores, e impulsaron una serie de leyes económicas y sociales muy importantes en la historia del país. Desgraciadamente, dichas leyes no beneficiaron a las mayorías. Es más: las perjudicaron. Repartieron tierras y formaron los primeros grandes sembradíos de café, que fueron trabajados de manera forzosa por comunidades indígenas de todo el país. La finca se convirtió entonces en el eje de la economía y la sociedad guatemalteca, y el monocultivo de exportación se consolidó como forma de relación entre Guatemala y el resto del mundo.

\begin{tabular}{|r|l|}
\hline Colonia y época conservadora & Añil \\
\hline Reforma Liberal & $\begin{array}{l}\text { Café } \\
\text { Algodón }\end{array}$ \\
\hline Dictaduras & Banano \\
\hline Actualidad & Azúcar \\
& $\begin{array}{l}\text { Cardamomo } \\
\text { Palma aceitera }\end{array}$ \\
\hline
\end{tabular}

2. Las guerras dejaron sembrada la violencia en el corazón de la vida política del país. Desde entonces, las diferencias suelen arreglarse en la dirección de los más poderosos: quienes controlan las armas, el dinero, el poder.

3. Sin embargo, ni siquiera toda esa violencia y esa explotación lograron anular la digna resistencia de nuestras abuelas y abuelos. A lo largo de los periodos más duros, siempre hubo gente en este país buscando condiciones más dignas para todos.

\section{Hagamos algo juntas}

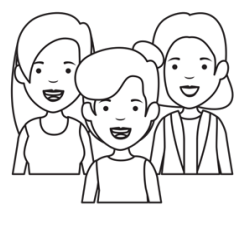

Luego de escuchar el relato, y de platicar sobre lo que nos hizo pensar, saldremos a dar un paseo por nuestra comunidad. Organiza de la mejor manera a las niñas y caminen con alegría hacia algún lugar público cómodo que esté cerca del lugar seguro donde se desarrollan habitualmente las sesiones. 
Mientras caminan, platiquen sobre lo que ven: las casas, los huertos, los edificios comunitarios, las tiendas, los locales, todo lo que esté a su alcance. Trata de estimular que las niñas hablen sobre su experiencia del espacio.

Al llegar al lugar público que elijas (puede ser un parque, un campo abierto, etc.) formen un círculo y siéntense con comodidad. Ahí podrán platicar de manera muy libre sobre los siguientes temas:

- ¿Qué le hace falta a nuestra comunidad?

- ¿QQué nos gustaría tener cerca?

- ¿̇Cómo podemos producir cambios en nuestra comunidad?

Es importante que todas seamos conscientes de nuestra responsabilidad comunitaria. Siempre podremos hacer algo -por pequeño que sea- para que nuestro entorno sea mejor. Y un elemento importante es abrir bien los ojos para percibir las necesidades más inmediatas. Por eso es importante pensar en el espacio que transitamos todos los días.

\section{Oportunidades en casa}

Antes de despedir la sesión, recuérdale a las niñas que platiquen en casa sobre los conocimientos que van adquiriendo en las sesiones de

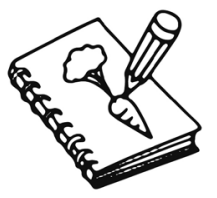
su grupo de Abriendo Oportunidades ${ }^{\circledR}$. Sus familiares estarán muy contentos de verlas aprender cada semana. Pídeles que le pregunten a sus padres si saben el año en que nacieron sus abuelos. La próxima sesión nos acercaremos en el tiempo, y es probable que hablemos de la época en que los abuelitos de las niñas empezaron a nacer. Indícales que recuerden el año, y que lo compartiremos al inicio de la siguiente sesión.

\section{Ruta hacia un proyecto comunitario}

Para terminar, recuérdales que deben avanzar cada vez más en su proyecto comunitario. En esta ocasión, será importante que distribuyas todas las tareas necesarias para llevar a cabo el proyecto, a fin de que todas las niñas tengan algo que hacer. Cada niña deberá estar muy consciente de la tarea que tiene a su cargo.

Puedes usar el cronograma que hicimos juntas hace un par de sesiones, y así todas podrán controlar mejor sus tiempos y responsabilidades.

$$
\text { Guia para mentoras de Abriendo Oportunidades }{ }^{(3)}
$$




\section{Sesión 10}

\section{Nuevas formas, para nuevas dictaduras}

\section{Hagamos memoria}

Hemos recorrido de la mano de Esperanza varios miles de años a lo largo de la historia de nuestros territorios y nuestras comunidades, y hoy nos acercaremos más a nuestro presente. Mientras las niñas van llegando a la sesión, trata de refrescar los conocimientos de las sesiones previas, platicando con ellas sobre lo que recuerden. Cuéntales que esta vez empezaremos a hablar de la historia del siglo XX, un siglo muy importante para la humanidad entera.

\section{Nuestras grandes preguntas}

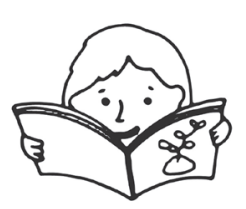

Pregúntales a las niñas el año de su nacimiento, y ve anotando las cifras que te den en un papelógrafo o en un lugar visible para todas. Cuando terminen, hagan juntas el recuento de los años que aparecen. ¿̇Verdad que todos pertenecen ya al siglo XXI?

Cuéntales que hace poco más de 100 empezaron a pasar sucesos muy importantes para los pueblos que hoy ocupan Guatemala, y que en las últimas sesiones abordaremos lo que ha sucedido en el país entre 1898 y el presente.

Pregúntales también si recuerdan las fechas de nacimiento de sus abuelos (que debieron preguntar en su casa a lo largo de la semana). Anótalas en otra lista, y analízalas con las niñas. Piensen juntas en la distancia de tiempo que las separa de sus abuelos, y todo lo que puede pasar en ese rango de tiempo.

\section{Los relatos de Esperanza}

Hoy Esperanza conocerá una palabra -y una experiencia histórica- que no ha oído nunca. Se trata de la palabra dictadura. ¿̇a conocen? Escuchemos con atención este relato, e imaginemos a nuestra amiga Esperanza en su proceso de aprendizaje:

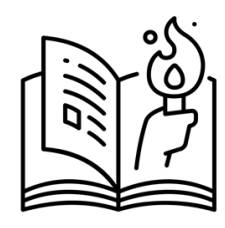

\section{Tenemos que inventarnos otras formas}

En su grupo de Abriendo Oportunidades ${ }^{\circledR}$, Esperanza y sus amigas aprendieron cómo hacer un huerto familiar. Cada una tiene ahora uno en su casa, y poco a poco han empezado a producir sus alimentos y 
a intercambiar lo que no tienen con las otras niñas. Es un trabajo que requiere mucha paciencia, pero Esperanza la ha tenido, aunque quisiera ver ya todo lo que ha sembrado sobre una mesa, diciéndole a su abuelito que no compre esto o lo otro para que no gasten dinero.

Una vez hasta soñó que salía de su cuarto y con sus manos les decía a las plantas que crecieran, que crecieran rápido, y cuando volteó a ver el huerto se había perdido entre tanta vegetación que cubría la casa y empezaba a subir hacia el cerro... Cuando despertó, Esperanza supo que esa era una buena señal: estaba hablando con su huerto en los sueños, y el huerto le decía que iba a crecer bien, que tuviera paciencia.

Esta semana, Quetzalí va a pasar a las casas de las niñas para revisar los huertos. Va a llegar con unas personas de la capital que tomarán fotos y les harán preguntas, porque las niñas que siembran -como Esperanza y sus amigas-se han vuelto famosas, y pronto se llevará la idea de los huertos a otros lugares del país. La niña limpió y arregló su huerto lo mejor que pudo, se arregló ella y hasta le dijo a su abuelo Lix que se arreglara también, por si querían tomarle alguna foto. Ella les pensaba contar que su abuelo cuenta los días y sabe las energías que hay en cada uno de ellos, y que eso le ha ayudado mucho para la siembra.

El día acordado, Quetzalí llegó temprano a la casa de Esperanza. Pero su amigo -el que tenía que llegar con la cámara para hacer preguntas- aún no llegaba. Tuvieron que esperarlo un rato. De pronto apareció un picop, y de él bajó el muchacho con su mochila al hombro y la cámara en las manos. Iba acalorado y cansado. Pidió muchas disculpas por haberse tardado, y le contó a Quetzalí que venía de una comunidad lejana, que estaba en medio de una inmensa plantación de palma africana.

-Vaya que ahora voy a hacer esto, vos, en este huerto que se ve tan lindo -les dijo-, porque vengo de un lugar que dejó muy triste y enojado.

Saludó amablemente a don Lix. Le dio un a Quetzalí -con un poco más de confianza, porque ya era su amiga- y a Esperanza le dijo:

- Me alegra conocer a la famosa Esperanza, la niña de las preguntas. Yo soy Marcos, y a mí también me encanta hacer preguntas.

Ella se rió sin saber muy bien por qué le decía eso, y le indicó que pasara adelante para presentarle su huerto. Él estaba feliz, ya repuesto del viaje, tomando fotos y preguntándole cuándo sembraba cada planta.

Después de un rato, Marcos le contó a Quetzalí que lo que había visto era demasiado: era una comunidad entera atrapada en la plantación de palma, sin caminos, sin agua potable, en medio de la miseria, con hambre, víctimas de la violencia que ejercían las personas que cuidaban la tierra de los dueños, que prácticamente no habían llegado nunca a su propiedad. "Esa pobre gente vive como en una dictadura", le dijo Marcos.

-Vieras, Queztalí. La gente se puso a contarnos de todo. Hasta unos dibujos habían hecho, para que tuviéramos claro que estaban siendo violentados de muchas formas. Nos entregaron cartas para que los ayudemos. Están encerrados, tal y como pasa con los países con dictadores, solo que acá los dictadores son los palmeros y sus capataces. Es horrible. No sé qué vamos a hacer para ayudarlos, pero algo tenemos que hacer. Los niños están desnutridos y la verdad es que los grandes también. iEstán flaquísimos! Imaginate, ni agua tienen. Como toda el agua es para la palma, a ellos los están ahogando.

$$
\text { Guia para mentoras de Abriendo } O_{\text {portunidades }}{ }^{\circledR}
$$


Eso iban platicando mientras caminaban entre los cultivos de Esperanza. Don Lix iba cerca de ellos, y Marcos aprovechó para platicar un poco con él mientras le tomaba unos retratos. Después de unos minutos, el abuelo de Esperanza los invitó a tomar un fresco que había preparado.

-Es increíble -dijo don Lix. Aquí pasa el tiempo y las historias se repiten una y otra vez. Ahora es la palma, antes era el banano, antes el café... siempre miran qué más sacarle a la tierra, aunque la gente que viva en esa tierra se muera de hambre. Total, ia ellos qué les importa!

-¿¿Qué es una dictadura? -preguntó Esperanza, cuando recordó esa palabra rara que no había escuchado antes y que Marcos mencionó mientras caminaban por el huerto.

Los tres adultos se quedaron esperando a ver quién respondía. Finalmente su abuelo le dijo:

-Aquí, en estas tierras, vaya si no sabemos qué es una dictadura. Es un régimen en el que alguien tiene el poder absoluto. Hace lo que se le antoja con el pueblo y a su conveniencia, y no hay leyes que puedan evitar que lo haga. En este caso, el amigo Marcos dice que es una dictadura porque los dueños de las siembras de la palma son los que deciden qué hacer o dejar de hacer con la gente que vive en esas comunidades. Se quedaron atrapados, supuestamente como trabajadores, pero ganan tan poco y están tan aislados que casi diríamos que parecen esclavos.

-Además -dijo Marcos-, en las dictaduras los países se quedan aislados del mundo. Es como que si encerraran a todo el país, sin contactos, casi sin poder pedir ayuda. Eso ha pasado aquí en Guatemala varias veces, y lo que dice tu abuelito es cierto: antes era el café, el banano, cualquier cosa, pero los invasores de nuestras tierras siempre han encontrado cómo sacar provecho.

- ¿Ahorita hay dictadores entonces? -preguntó Esperanza con preocupación.

-No precisamente, pero el resultado es como si los hubiera. Antes eran personas, con nombre y apellido, y ahora son sistemas los que nos quitan todo, los que nos encierran -dijo Marcos.

$-\dot{2} Y$ quiénes han sido los dictadores de aquí?

-Uy, mija, la lista es larga. A finales del siglo diecinueve estuvo Manuel Estrada Cabrera. Unos años después de lo que te conté sobre los alemanes, él se aprovechó de que habían matado a un presidente y subió al poder. Y otra vez la misma historia: a regalar tierras, sólo que ahora no a los alemanes sino a los gringos. Esas gentes hicieron fiesta sembrando frutas, sobre todo bananos. Hasta un su tren les hizo Estrada Cabrera, para que sólo ellos lo usaran. Mientras tanto, el país entero estaba como encerrado.

-i¿̇Otra vez regalando tierras?!

-Así es, mija, han hecho lo que quieren con esta tierra, le han sacado jugo. Y a nosotros nos han dejado apenas sobreviviendo. Imaginate: 22 años estuvo Estrada Cabrera en el poder, porque a los dictadores si no es con revoluciones no nos los podemos quitar de encima. A él lo quitó una revolución: la gente logró que lo declararan loco, y yo digo que sí estaba algo loco, porque żcómo va uno a regalar así su país? Pero bueno, igual era el otro don del billete de a cinco que te contaba el otro día.

-Qué raro que este Estrada Cabrera no salga en un billete -dijo Esperanza, y todos soltaron una carcajada. 
-Solo eso faltaba -dijo Quetzalí.

-Ah, pero no sería raro que un día vengan y lo pongan. Porque todos estos que son dueños del país son felices con la imagen de los dictadores. Si ellos hacen lo mismo -dijo Marcos, sin quitar el gesto de enojo de su cara.

-Pero qué bueno que hubo una revolución, żverdad? -dijo Esperanza.

-Ay dios, pero casi nada duró el gusto, mija. Al rato ya había otro dictador encaramado en el poder, maltratando a la gente. Ese se llamaba Jorge Ubico. Catorce años estuvo mandando, mientras los gringos hacían fiesta con los bananos que vinieron a sembrar. Así como la gente que ahorita está atrapada entre la palma, así tenían a todo el país. Pero a él lo quitó también una revolución, y esa sí que fue buena. Duró sólo 10 años, pero ya te voy a contar todo lo que se logró en ese tiempo. Lástima que también la botaron.

-Lo triste es que pasan los dictadores, pasan los años, las guerras y las revoluciones, y siempre volvemos a caer en estos casos tan tristes -dijo Quetzalí.

-Es que esto que vi hoy es demasiado, ustedes. ¿̇Cómo pueden tener a la gente encerrada? Ya hace más de 100 años que tiraron a Estrada Cabrera, pero como que dejó bien enseñada la lección para mantener a la gente sometida. Yo no sé qué tipo de revolución habría que hacer para curar estos males, para sacarnos las enfermedades profundas que hacen posible esto.

Esperanza lo escuchaba todo mientras veía por la ventana su huerto y el cerrito detrás de su casa. Y sintió que a pesar de la angustia y la frustración de su abuelo, de su nuevo amigo Marcos y de su querida mentora Quetzalí, algún camino tenía que haber.

- Hay que enseñarle a todos a hacer sus propios huertos -les dijo de pronto-. Hay que exigir que le abran un camino a la gente de la comunidad.

Marcos se sonrió con ella y le dijo:

-Sí: tenemos que inventarnos otras formas de hacer revoluciones.

Pregúntale a las niñas qué piensan del relato que acabamos de escuchar. ¿̇Les ha sucedido algo parecido? ¿Conocen o han oído hablar de alguna situación como la que se relata?

\section{Recuerda tener claro que:}

1. Las dictaduras fueron una constante durante siglos en Guatemala. Ya los conservadores y los liberales del siglo XIX solían acumular todo el poder en una persona y ejercerlo durante décadas. Sin embargo, con la de Manuel Estrada Cabrera se agudizan muchas situaciones que tienen mucho peso en la vida política y social de Guatemala hasta el día de hoy.

2. Uno de los grandes efectos de las dictaduras de Estrada Cabrera y Jorge Ubico fue poner freno al desarrollo normal de la vida social, incluyendo sus aspectos más íntimos y sencillos. La falta de libertad se dio en todas las esferas de la vida, y los recursos del país fueron puestos al servicio de capitales extranjeros, que multiplicaron la pobreza y la mala calidad de vida para prácticamente toda la población.

3. En el presente, no tenemos un dictador con nombre y apellido al que podamos identificar con claridad, sino que las dinámicas de todo tipo que dejaron las dictaduras

$$
\text { Giva para mentoras de Abriendo } O_{\text {portunidades }}{ }^{\circledR}
$$


se hicieron más complejas y ahora es todo un sistema el que nos oprime. ¿̇Podemos vencer a ese sistema con las mismas formas de hace 100 años? Es difícil. Por eso, déjales claro a las niñas que debemos ser creativas en todo momento para que el deseo de alcanzar el buen vivir para todos sea más accesible.

\section{Hagamos algo juntas}

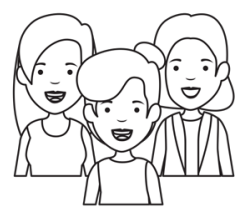

Antes de realizar esta actividad, sería bueno que investigues un poco sobre los distintos métodos para producir alimentos. ¿ Qué implica cada uno para nuestra salud y para la salud de la tierra? Este conocimiento general te ayudará a desarrollar mejor esta parte de la sesión.

Diríjanse a un lugar fresco, cómodo, de ser posible al aire libre.

Diles a las niñas que hoy pensarán juntas en una actividad que hacemos todos los días de nuestra vida, incluso antes de nacer. ¿̇Qué actividad es? Alimentarnos, comer.

Realicen la siguiente actividad:

1. Pregúntale a las niñas qué han comido durante los últimos días. Puedes ir anotando las respuestas que te den en un cuaderno, o en una hoja en blanco. Trata de que todas participen.

2. Ahora, cuando hayan completado el listado de alimentos, pregúntales lo siguiente: ¿De dónde viene toda esa comida? Ve anotando sus respuestas. Traten de pensar no sólo dónde se compran o se consiguen los alimentos, sino dónde se producen.

3. Pídeles que piensen en dos elementos importantes para la producción de alimentos: quién los produce y qué necesita para producirlos. Hagan una lista de las distintas personas y las distintas cosas que se necesitan para producir los alimentos que consumimos.

4. Por último, pregúntales cómo se consigue la comida que llega a su casa: ¿̇se compra, se intercambia, se cultiva?

Luego de la discusión que tengan todas juntas, comparte con ellas esta breve reflexión:

Cada vez que comemos estamos formando parte de un sistema, de una cadena de actividades que nos vincula con muchas personas y con el

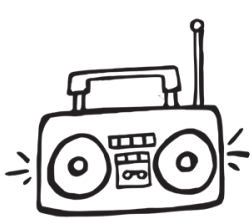
entorno que compartimos. Esa cadena puede alimentarnos bien y cuidar a la tierra, o bien puede hacernos daño y dañar nuestro entorno. Sin duda es mejor la primera opción, ¿̇verdad? Pues una de las revoluciones que está a nuestro alcance todos los días es mejorar nuestros hábitos de producción y consumo de alimentos. Si producimos lo que necesitamos y lo intercambiamos de manera justa con nuestra comunidad, estamos debilitando a un sistema que nos hace daño. Eso podemos hacerlo 
todos los días, desde nuestras casas. Comparte con ellas la importancia de hacer crecer un huerto familiar, para que en nuestra propia casa podamos ver crecer la comida que nos nutre.

\section{Oportunidades en casa}

Antes de despedir la sesión, déjale a las niñas la inquietud de conversar con sus papás sobre la posibilidad de tener un huerto familiar cerca de su casa, en caso de que no lo tengan aún. Pídeles que dialoguen sobre lo que necesitarían para poder empezar su huerto, y que sueñen juntos en lo que podrían lograr sembrando y cultivando su propia comida. 


\section{Sesión 11}

\section{Una revolución es movimiento}

Las niñas que integran tu grupo de Abriendo Oportunidades ${ }^{\circledR}$ son tus amigas. Recíbelas como tales, y pregúntales cómo han estado, cómo van las cosas en su casa y cómo se sienten. Escúchalas con atención, y comparte con ellas tus experiencias mientras se reúnen para esta sesión.

\section{Hagamos memoria}

En las últimas semanas hemos hablado de personas poderosas que, durante muchos años, regalaron las riquezas, las tierras y hasta la fuerza de trabajo -por no decir la vidade la gente en Guatemala. ¿ Recuerdan a los conservadores y los liberales? ¿ Recuerdan a los dictadores? ¿Quiénes fueron? ¿Qué hicieron? ¿En qué nos siguen afectando hoy algunas de sus decisiones? Pídele a las niñas que refresquen su memoria.

\section{Nuestras grandes preguntas}

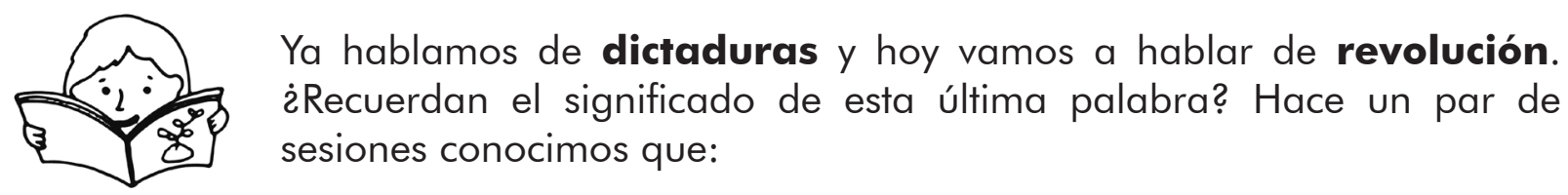

Una revolución es un cambio profundo, y generalmente violento, en las estructuras políticas y económicas de una sociedad. A veces, cuando los pueblos participan en ellas, esos cambios pueden ayudarles a mejorar sus condiciones de vida. Pero cuando eso no sucede, las cosas pueden empeorar por el egoísmo de quienes toman el poder.

Pregúntales: ¿Qué debe pasar para que una revolución sea buena, y traiga beneficios para la gente más necesitada?

\section{Los relatos de Esperanza}

No todo en nuestra historia es triste, y hoy lo aprenderemos junto a Esperanza. Ya hemos hablado de muchas resistencias, y de la dignidad y lucha de muchas personas. Pero hoy hablaremos de un movimiento colectivo que es fundamental para la Guatemala del presente y el futuro. Pongamos atención al relato y acompañemos a Esperanza para encontrarse con una Guatemala que no conocía: 


\section{Todas estuvimos en 1944}

Imaginar una revolución, inventarla, juntar todo lo que no está bien: nuestras tristezas, nuestras necesidades, nuestros sueños irrealizables, nuestra hambre, nuestro río robado, la gente atrapada en las plantaciones, la gente que se tiene que ir lejos para trabajar y mantener a su familia,

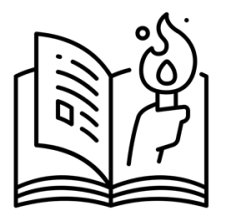
el miedo, las diferencias que duelen como heridas, la incomodidad de estar en lugares donde nos ven diferentes... juntarlo todo y desenredar los hilos con paciencia, desatar los nudos de nuestra historia. Todos los nudos, los dolores, las injusticias... Esperanza escuchaba su propia voz, pero no era sólo su voz: tenía otro tono en su cabeza, como un eco, como muchas voces juntas. Así se fue quedando dormida, y con estas ideas del lado de los sueños iba a preguntarle al cielo, a su corazón del cielo, a la tierra, a su corazón de la tierra, cómo hacer para desatar los nudos que nos tienen mal desde hace tanto.

Cuando se levantó, sintió una tristeza profunda. Su abuelito la cuidaba, se cuidaban juntos, pero le hacían falta su mamá y su papá. Ya casi no los recordaba. Se habían ido hace casi 10 años a Estados Unidos para buscar trabajo, porque en su aldea no tenían más opciones. Por eso, cuando el día anterior su abuelo le contó que el dictador había regalado riquezas a Estados Unidos, sintió un gran peso, como si tuviera que soportar una piedra. ¿Por qué se dieron todos esos regalos? ¿Por qué para allá se va la gente que necesita dinero? ¿Qué es lo que pasa con Estados Unidos? ¿Por qué está tan presente en nuestra vida?

Esperanza salió esa mañana sin preguntarle nada a su abuelo. La verdad es que tantas preguntas con respuestas dolorosas a veces la hacían sentir triste. Pero eso no significaba que las preguntas no existieran. ¿Cómo habían sido esas revoluciones de las que hablaban ayer? ¿Cómo pasaron? ¿Por qué si ya tuvimos revoluciones las cosas siguen estando mal? Quería saber tantas cosas, pero las respuestas ya le daban miedo.

Durante algunos días estuvo llevando sus chiles, remolachas, zanahorias y coliflores a una tienda. Así pudo ganar algo de dinero y no tuvo que pedirle a su abuelo. Esa tarde fue ver a la tienda si ya habían vendido algo. Le dieron un billete de 10. "Hoy voy a ir al internet", se dijo. Su intención era poner en el buscador "Revoluciones de Guatemala", como había visto hacer a Quetzalí.

Así lo hizo. Y la cantidad de información que recibió, lejos de calmar sus inquietudes, se fue convirtiendo en admiración por las resistencias de su gente, dolor por las heridas inmensas que le han hecho a su país, y rabia-muchísima rabia-por la cantidad de despojos en que ha vivido sumida la población guatemalteca durante siglos.

Esa tarde conoció el nombre Jacobo Árbenz Guzmán y Juan José Arévalo, conceptos como Junta Revolucionaria de Gobierno, Constitución de la República. "¿Pero y todo esto por qué no lo hemos aprendido bien en la escuela?", se preguntaba Esperanza. Había algo que la conmovía muchísimo: a través de un video supo que los primeros en lanzarse a la calle para manifestar su descontento contra la dictadura de Jorge Ubico eran los estudiantes. Gente muy joven, que tendría quizá cinco o seis años más que ella. "Eso quiere decir que no hay que esperar a ser grande para hacer una revolución", pensó Esperanza.

$$
\text { Guia para mentoras de Abriendo Oportunidades }{ }^{(B)}
$$


Las circunstancias que llevaron a esos jóvenes a hacer una revolución se parecían tanto a lo que ella veía en su aldea, a lo que les contó Marcos, a las necesidades grandes de la gente que conocía. Ella misma vivía sin sus papás porque ellos no tuvieron más opción que irse a Estados Unidos, y ahora tenía claro que Estados Unidos se había convertido en un país tan poderoso gracias a los despojos; gracias a que los dictadores no solamente eran autoritarios y violentos, sino que cedían tierras, ofrecían al país como regalo, como si no tuviera gente adentro, como si esa gente fuera parte del regalo.

Los bananos aparecían por todos lados en los sitios que consultaba. Le daba tanto enojo imaginarse los vagones de trenes llenos de bananos sembrados en estas tierras y yéndose a Estados Unidos, para que allá se ganara dinero, para que ese lugar fuera rico y poderoso, a costa de tanta hambre, de miseria, de esclavitud.

Pero esa indignación que se fue acumulando, que salió a las calles de la capital, que se movió por todo el país, logró quitar a un dictador: a Jorge Ubico. A partir de ese momento, la imagen de Jacobo Árbenz se convirtió en un referente para Esperanza. Entre los videos que pudo encontrar, había visto un documental entero sobre él, había escuchado a un viejito de nombre Carlos Guzmán Böckler hablando tan claramente sobre la circunstancia del país, que sintió que había entendido algo. Resonaban en su cabeza palabras como racismo y explotación, pero también resistencia, fuerza, valentía.

Cuando regresó a su casa, su abuelito estaba sentado en el corredor. Se había hecho tarde y se había empezado a preocupar.

-Mija, ¿̇pero dónde has estado? Ya tenía yo angustia.

-Tata Lix, es que con lo que nos contó ayer Marcos y con lo que usted dijo de la dictadura, yo la verdad es que tenía muchas dudas, y me fui a meter a un internet a investigar.

-Bueno, ży no te puedo yo aclarar las dudas, pues?

-Sí, Tata, pero es que a veces siento que mis preguntas provocan que después nos quedemos enojados o tristes.

-No, mija, no son tus preguntas: es la circunstancia de siglos que pesa sobre nuestro pueblo. Pero contame, żqué averiguaste?

Esperanza le dijo varios conceptos: Revolución de Octubre de 1944, Estudiantes organizados, Manifestación; le dijo Jacobo Árbenz, Jorge Toriello, Francisco Javier Arana; le dijo dignidad, le dijo esperanza, le dijo país...

-Y mire, Tata Lix, me puse a buscar fotos de la Revolución del 44 y le pedí al muchacho del internet que me imprimiera esta. Me costó un quetzal, pero creo que valió la pena. Igual traje varias cosas para comer, no me gasté el dinero sólo en esto.

Don Lix vio la foto impresa del Triunvirato de la Revolución. Sus ojos llorosos otra vez veían a Esperanza y veían la fotografía que traía, y de golpe se le apareció la memoria que él tenía de su papá, un hombre dispuesto a luchar desde el campo por la dignidad de todos.

-Sabés -le dijo don Lix-, yo guardo pocas cosas... Pero vení, te voy a enseñar algo.

Entraron al cuarto y arriba de su ropero tenía él una cajita. La bajó y fue sacando uno a uno los objetos, poniéndolos sobre su cama. La foto de Cándida, la abuela de Esperanza que había muerto de una forma que a su abuelo no le gustaba contar. La foto del casamiento de Dolores y Pablo, los papás de Esperanza. Una estampita de un Jesús 
que está en una iglesia de Tactic... Pero debajo de esas cosas -que tampoco eran tantashabía un papel viejo, doblado en cuatro.

-Desdoblalo. Mirá lo que es.

Esperanza se sorprendió. Era exactamente la misma imagen que ella había impreso en el internet. Pero viejita, muy viejita, recortada de un periódico de 1944.

-Mi papá apoyó la Revolución -le dijo orgulloso don Lix-, organizó a los campesinos, celebró cuando ganaron. Tuvo esperanza.

-Abuelito, la Revolución fue buena. Yo vi que hasta hicieron leyes, que los presidentes de ese tiempo querían cambiar todo desde las escuelas, desde las tierras. Era como que el país estaba naciendo.

-Así como lo decís, mija. Fueron 10 años buenísimos. Yo iba a la escuela y hasta desayuno y almuerzo nos daban. Y nos educaban muy bien. Cuando se supo aquí que la Revolución había ganado yo era muy chiquitillo, y por eso no me acuerdo. Pero los años de mi infancia fueron buenos. A pesar de que las penas no se acababan, había un camino.

Esperanza le preguntó por su bisabuelo: ¿¿ué hacía? ¿ Cómo apoyó a la Revolución?

-Mañana te cuento, mija, pues ya es tarde. Pero mirá, una cosa es segura: esa Revolución está adentro de todos, hasta de los que no la vivieron, porque a decir verdad el país que habitamos todavía hay que fundarlo, todavía está en formación, y para que eso pase necesitamos tener la memoria fresca, recordar esos años, aunque no los hayamos visto.

Esperanza se quedó pensando nuevamente en cómo hacer una revolución ahora, en cómo hicieron esos jóvenes para hacerla hace tantos años. Pensó en las niñas y los niños del futuro, en sus casas, en su comida, en sus tierras. "Ojalá ellos no tengan la necesidad de inventar revoluciones, ojalá lo que pase en estos años a ellos les sirva, ojalá logremos imaginar una nueva revolución". Se preparó para dormir, y antes de acostarse pegó su foto del Triunvirato en la cabecera de su cama. "Este", se dijo, "será mi recordatorio de todo lo que tenemos pendiente".

¿Qué les pareció el relato? ¿Qué sabían de la Revolución de Octubre de 1944?

\section{Recuerda tener claro que:}

1. Luego de años de opresión política, económica y social, muchos sectores de la sociedad guatemalteca coincidieron en la necesidad de transformar las cosas. La madrugada del 20 de octubre de 1944 se produjo un movimiento para derrocar la dictadura. Los estudiantes universitarios y de nivel medio jugaron un papel fundamental en este movimiento. Esa fecha es importante para la historia guatemalteca, pues con ella inicia un proceso de transformación que no se había visto antes en el país. En pocos meses se construyeron leyes e instituciones de beneficio popular, y se eligió con libertad por primera vez a un gobernante.

2. Si bien los nombres más relevantes de la Revolución de Octubre son los de Jacobo Árbenz, Jorge Toriello y Francisco Javier Arana, en este proceso participaron muchísimas

$$
\text { Guia para mentoras de Abriendo Oportunidades }{ }^{(3)}
$$


personas de los más diversos sectores, demostrando que la unidad es muy importante cuando se buscan cambios políticos de verdad.

3. En 1944 Guatemala empezó a modernizarse como nunca antes en su historia. Ni siquiera la independencia de España, más de 100 años antes, significó tantos cambios para la vida en el país. Se quería construir una sociedad moderna, más justa y libre.

\section{Hagamos algo juntas}

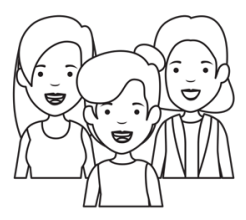

Las revoluciones no empiezan si antes no nos damos cuenta de las circunstancias que nos afectan y que debemos cambiar. A veces, esas circunstancias son tan grandes, que nos sentimos muy pero muy pequeñas y no encontramos formas para enfrentarlas. Lo cierto es que de una en una, con nuestras ideas y nuestras acciones, podemos ir desatando un movimiento que se contagie en la comunidad y que impulse los cambios que necesitamos para estar mejor.

La palabra revolución también tiene que ver con el movimiento. El diccionario nos enseña que una revolución también es un giro, una vuelta sobre nuestro propio eje. Así funcionan los motores, las bicicletas, los molinos: sus piezas giran, se mueven y permiten avanzar. ¿Y qué queremos nosotras, como comunidad? Precisamente eso: avanzar, movernos, transformarnos y vivir mejor.

Reflexiona sobre esto con las niñas, e invítalas a realizar la siguiente actividad:

1. Diríjanse a un patio, un lugar cómodo, de preferencia al aire libre.

2. Formen un círculo guardando cierta distancia entre cada una de las niñas. La idea es que cada una pueda extender sus manos, y al hacerlo alcance a tocar las manos de las niñas que tenga a la par.

3. Todas estarán de pie y con los brazos extendidos. Indícales esta dinámica: una niña empezará a girar sobre sí misma, y cuando lo haga tocará la mano de la niña que tiene a la par. Al sentir ese contacto en su mano, la segunda niña empezará hará lo mismo: girará sobre sí misma y tocará la mano de la niña que tiene a la par. Así, todas las niñas irán empezando a moverse en círculos cuando sientan que su compañera les toca la mano.

4. Ríe con ellas, pídeles que sientan cómo el movimiento de las otras niñas les va llegando y cómo ahora ya no sólo es una la que se mueve, sino todas.

5. Cuando ya todas hayan girado -lentamente, para no marearse-, paren y respiren profundo. Relájense y perciban lo que siente su cuerpo luego de ponerse en movimiento con la energía de todas las demás. Cuando todas nos movemos juntas, la fuerza que tenemos es mayor. 


\section{Las palabras que nos nombran}

Un escritor magnífico que se llama Augusto Monterroso, y precisamente este año estaría cumpliendo 100 años, nos regala este pequeño fragmento que habla directamente de nosotras:

"... estoy seguro de que de algún modo, en alguna parte, tal vez con otro nombre u otro apellido, la Revolución de Octubre se encuentra viva, está creciendo, está bien".

¿A qué se refiere nuestro amigo escritor? Se refiere a todas esas iniciativas-como Abriendo Oportunidades, como cada uno de los huertos que florecen en los patios de las niñas, y cada idea que queda en ellas a partir de estas sesiones- que buscan la libertad, la alegría y la dignidad de la vida en Guatemala. Déjale claro a las niñas que todas las personas, los proyectos y las ideas que buscan el buen vivir en nuestro país están conectados.

\section{Oportunidades en casa}

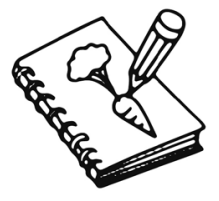

Dile a las niñas que la historia de nuestras familias siempre está vinculada con la historia de nuestra comunidad mayor, que en este caso es nuestro país. Por eso, pídeles que investiguen en su historia familiar: ¿̇ué relación tuvieron los miembros de su familia con la Revolución de Octubre de 1944? Pueden recordar los relatos y compartirlos luego, pueden hacer dibujos que las ayuden a recordar. Sean creativas y conozcan poco a poco su historia familiar.

\section{Ruta hacia un proyecto comunitario}

Es momento de ir avanzando, pues las semanas pasan y nuestro proyecto comunitario debe estar listo para la fecha prevista en nuestro cronograma. Consulta con las niñas cómo van las tareas que le corresponden a cada una, y pregúntales si necesitan alguna ayuda para poder realizarlas. Diles que dediquen un poco de tiempo diario -o cada vez que les sea posible- para no tener prisas al final del plazo. 


\section{Sesión 12}

\section{Una revolución es construir}

\section{Hagamos memoria}

La semana pasada pudimos conocer algunos detalles de un momento muy importante de nuestra historia. Pregúntale a las niñas qué recuerdan: ¿2Qué te pueden decir de la Revolución de Octubre de 1944? ¿Recuerdan lo que le pasó a Esperanza luego de ir a investigar al internet de la comunidad? Juntemos lo que recordamos y avancemos en esta sesión.

\section{Nuestras grandes preguntas}

Cuando todas estén reunidas, siéntense y reflexionen sobre el entorno de

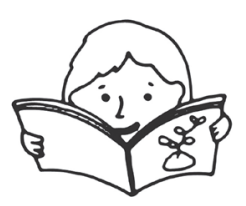
su comunidad. ¿Qué tipo de propiedades hay: fincas, plantaciones, huertos, tierras comunitarias? ¿Hay cooperativas? ¿Los campesinos tienen tierras propias para cultivar? Analicen su entorno y piensen si la distribución actual de las tierras cercanas es justa. Si no lo es, ¿̇qué creen que podría hacerse para mejorar?

\section{Los relatos de Esperanza}

Esta pregunta se hicieron muchas personas hace más de 70 años. Y hoy, junto a Esperanza, nos daremos cuenta de que algo de esa historia está dentro de nosotros ahora mismo. Escuchemos con atención:

\section{La memoria que llevamos dentro}

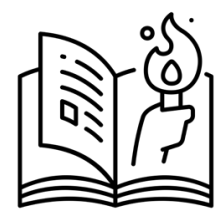

El bisabuelo de Esperanza se llamaba Macario. Era un campesino que tuvo que trabajar en las fincas cafetaleras por muy poco dinero y con grandes necesidades durante las dictaduras. Su esposa se llamaba Feliciana, y era comadrona. Sus vidas no eran fáciles. Su trabajo era durísimo y tenían muchas necesidades.

Siempre escuchaban decir a los patrones y a los capataces que la gente de su comunidad era pobre porque no les gustaba trabajar. Como si no los vieran levantarse antes que el sol y trabajar de una forma tan fuerte, casi como si fueran máquinas de carne y hueso para las que el cansancio era ya una forma permanente de existir.

-Siento que tendría que volver a nacer para que se me quite este cansancio -le decía a veces Macario a Feliciana, que se dedicaba a recibir a las criaturas, a hablarles desde 
que estaban adentro de sus mamás, a contarles cómo era el mundo.

A pesar de todo, Macario y Feliciana estaban enamorados de la vida. Eran conscientes de su cansancio y de sus penas, sabían que su trabajo era casi una esclavitud, pero eso no impedía que todos los días se dedicaran a ver salir el sol sobre los cerros. Disfrutaban mucho cuando el día estaba naciendo, y veían la perfecta armonía en que pasaban las cosas en la naturaleza. Este es un paraíso, pensaban, pero en este paraíso muchos hemos vivido un infierno.

-Tenemos que hacer algo, Macario. El hambre no se nos va quitar ni cuando estemos muertos si no hacemos nada.

Las palabras de Feliciana sorprendieron a su esposo, que respondió:

-He pensado que necesitamos hablar con los compañeros y ver si hacemos una reunión para exigir que nos paguen más y que se nos conceda un poco de tierra para sembrar algo que nos ayude a alimentarnos mejor, sin tener que pasar tantas penas. Además, las criaturas tienen que estudiar, y acá ni eso se puede con tanta miseria.

Así lo hicieron. Poco a poco la gente se fue organizando. De lejos les llegaban noticias sobre una revolución que había triunfado. Se oía que las cosas iban a cambiar, y que quizá los campesinos organizados podrían ser parte de esos cambios.

Se enteraron que habría elecciones libres, y decidieron participar. Resultó electo el presidente Juan José Arévalo, y según oían Feliciana y Macario, él quería que la educación se convirtiera en una vía para cambiar las condiciones del país. Curiosamente, esa iniciativa que ellos habían tenido coincidió con que en la capital de la república el Presidente había firmado el Código de Trabajo, gracias al cual ya no tendrían que trabajar tantas horas al día y podían ganar un poco más de dinero.

Feliciana y Macario tenían tres hijos: Berta, Felipe y Andrés, a quien todos le decían Lix. Ya habían logrado que todos fueran a la escuela, y eso les sirvió mucho porque, además del aprendizaje, en la escuela recibían alimentos y los cuidaban muy bien. Las cosas estaban cambiando, lentamente pero cambiando, porque al parecer se iba aclarando el camino para avanzar hacia una vida que se pareciera más a la belleza que veían cada vez que empezaba el día.

Pasaron los años, y la organización de los campesinos se fortaleció. En 1950, cuando iban a ser las elecciones, Macario organizó a todos sus compañeros para apoyar a un candidato cuyo nombre conocían muy bien: el Coronel Jacobo Árbenz Guzmán, que fue uno de los dirigentes de la Revolución.

Por esos días, el candidato Jacobo Árbenz llegaría de visita a la cabecera municipal, y Macario y Feliciana quisieron aprovechar para ir a la reunión y escuchar sus palabras.

-Pero hagamos un nuestro cartel -le dijo Feliciana a su esposo-, que Árbenz sepa que queremos que gane, y que vamos a trabajar con él para que las cosas mejoren.

Así lo hicieron: en una tela y con pintura escribieron un rótulo que decía:

"El pueblo está con Árbenz, porque Árbenz es el pueblo".

Le pusieron dos varas de madera a cada extremo y entre los dos lo levantaron cuando llegó el candidato. Entre la multitud que lo escuchaba, Macario y Feliciana supieron que Árbenz los había visto, porque en medio de su discurso dijo: "El pueblo está con Árbenz, porque Árbenz es el pueblo", y al pasar cerca les dio la mano y les dijo que iban a trabajar juntos, porque para él ser presidente era trabajar con el pueblo.

$$
\text { Guia para mentoras de Abriendo } O_{\text {portunidades }}{ }^{(0}
$$


Árbenz ganó las elecciones, y se convirtió en presidente el 15 de marzo de 1951. Ahí empezó una época muy importante para todos en Guatemala. Los planes se empezaron a desarrollar y las cosas iban mejorando, pero aún era demasiado difícil todo.

La gente necesitaba tierra. Feliciana y Macario sentían una gran frustración al ver la cantidad inmensa de tierras que ellos mismos trabajaban y que les daba tan poco, porque todo lo que se ganaba era para los dueños, no para ellos. No alcanzaba la vista para ver el final de las propiedades de los patrones. Se oía que la Compañía Frutera era la dueña de las mejores tierras del país, y que todo el banano que producían se iba a Estados Unidos y la ganancia se quedaba muy lejos. En cambio, los campesinos guatemaltecos tenían unos pedazos de tierra tan chiquitos que su producción apenas alcanzaba para tener muy poco de comer.

Después de un tiempo se empezó a escuchar de la Reforma Agraria, del Decreto 900. A través de ese nuevo decreto, se iban a entregar las tierras ociosas -es decir, las tierras que no se estaban sembrando- a los campesinos. Esas tierras pertenecían a las familias más poderosas y a los dueños de la Compañía Frutera, que no sólo producían banano sino controlaban el ferrocarril, la energía eléctrica y muchas empresas más.

Esa ley buscaba una vida más digna, más feliz y más justa para todos los campesinos en Guatemala. Para que esto pasara, era necesario que hubieran comités campesinos que se encargaran de informar de esas tierras ociosas, de organizar a las personas y de ejecutar en todo el territorio del país lo que la ley mandaba. Macario y Feliciana fueron parte de esos comités. Gente como ellos estaba haciendo posible que la Reforma Agraria fuera una realidad capaz de disminuir el hambre y la miseria.

-Ahora, cada vez que va a venir una criatura al mundo - decía Feliciana-, siento que le puedo contar que va a venir a un buen lugar. Se siente feliz mi corazón de saber que esa criatura no va a pasar tantas penas.

Pero hubo un momento en el que los grandes poderes económicos se sintieron muy amenazados, y por eso reaccionaron ante la Reforma Agraria, que ya estaba impidiendo que pudieran controlar totalmente las tierras de Guatemala, esas tierras que tanta abundancia les habían dado. No querían compartir esa abundancia con el pueblo. No podían permitirlo...

Feliciana y Macario trabajaron con amor por los que vendrían después de ellos, igual que mucha gente que se sintió apoyada, que sintió por primera vez que tenían un suelo en el cual apoyar sus pasos hacia el futuro. Quizá por eso Esperanza, que nunca vio a sus bisabuelos, siente ese mismo amor hacia la gente que no va a ver nunca, pero que tendrá adentro de sus cuerpos la memoria de las luchas y las resistencias. Esperanza quizá no lo sepa, pero guarda a Feliciana y a Macario dentro de su memoria dormida. Esa memoria que, justo ahora que nuestra amiga necesita imaginar las revoluciones del futuro, empieza a despertarse.

Resalta este último párrafo y coméntalo con las niñas después de escuchar el relato. Cuéntales que todas Ilevamos dentro las experiencias, las ideas, las ilusiones de nuestros antepasados. Aunque no seamos conscientes de ello, en nuestra vida diaria todo eso se va manifestando y nos da una fuerza muy grande para avanzar hacia el futuro. 


\section{Recuerda tener claro que:}

1. La Compañía Frutera llegó a Guatemala a inicios del siglo XX, y poco a poco acumuló un poder enorme debido a los regalos de los dictadores. Para 1950 era el principal terrateniente del país. Sus riquezas salían de inmediato a Estados Unidos y muchas de las tierras que poseía eran ociosas, es decir que no se sembraba nada en ellas y no le servían a nadie.

2. Por eso se creó un programa para hacer que esas tierras fueran útiles para los campesinos del país. Se llamó reforma agraria, y fue un plan cuidadosamente diseñado para mejorar la economía de las y los guatemaltecos. Fue impulsado por el presidente Jacobo Árbenz, pero muchos sectores de la sociedad trabajaron de la mano para llevarlo a cabo. Uno de sus principales objetivos era aumentar el poder adquisitivo de las familias campesinas en el país, y así estimular el comercio y el mercado interno. Ahora mismo, quizá no sea viable retomar un plan de esta naturaleza, por lo que es necesario pensar en otras alternativas para modificar la estructura social y económica del país.

3. En pocos años, se vieron los resultados: muchos campesinos accedieron a tierra y créditos y empezaron a producir. La economía mejoró notablemente. Pero los antiguos dueños, la Frutera y los grandes terratenientes no estaban contentos, y empezaron a buscar formas para interrumpir el proceso.

\section{Hagamos algo juntas}

Muchas veces se piensa que una revolución es una cosa de un día o dos.

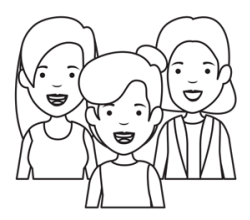
Que con botar a un presidente y sustituirlo por otro basta. Pero eso no es así. Una revolución verdadera consiste en crear una nueva realidad, en hacer cosas que no se habían hecho antes y en construir posibilidades nuevas. Por eso, una revolución es un proceso lento que puede tener muchas formas.

En la actividad de hoy las niñas pensarán una revolución desde su experiencia más cercana y personal. Tomemos como punto de partida esta pregunta: ¿̇Qué debo hacer yo, desde mi casa, todos los días, para que abrir nuevas oportunidades para mí y para mi comunidad? Tratemos de responderla.

1. Entrégale una hoja a cada niña, en donde cada una responderá a las siguientes preguntas con dibujos o con palabras, como se sientan más cómodas:

- ¿QQué quiero ser cuando sea grande?

- ¿Qué oportunidades necesito tener en mi casa para lograrlo?

- ¿QQué beneficio tendrá para mi comunidad mi trabajo en el futuro?

$$
\text { Guia para mentoras de Abriendo } O_{\text {portunidades }}{ }^{\circledR}
$$


Dales un tiempo prudencial para pensar en sus respuestas y para dejarlas plasmadas en la hoja, de la manera que más se les facilite. Luego, cuando hayan terminado, invítalas a que quienes quieran compartan lo que pensaron. Reflexiona con ella sobre lo importante que es poner nuestros anhelos, nuestras capacidades y nuestro trabajo en común para el beneficio de todas las personas que viven alrededor nuestro.

\section{Oportunidades en casa}

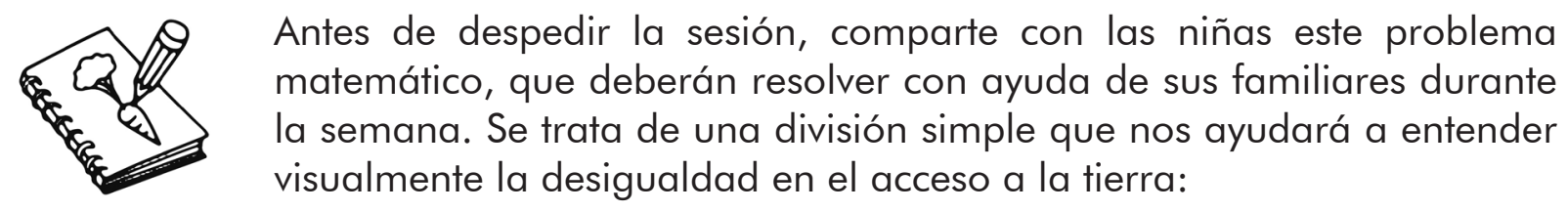

En una comunidad, hay 100 personas: tres terratenientes y 97 campesinos.

Los tres terratenientes poseen 70 parcelas. ¿Cuántas parcelas le corresponden a cada uno?

En cambio, los 97 campesinos poseen entre todos únicamente 30 parcelas. ¿Cuántas parcelas le corresponden a cada uno?

¿Qué piensan de los resultados? ¿Será justa esa distribución? ¿̇ los campesinos les alcanza lo que tienen para vivir tranquilos? ¿QQué hacen los terratenientes con el exceso de tierras que poseen?

Platiquen sobre esto en sus casas, y compartan su experiencia al inicio de la próxima sesión. 


\section{Sesión 13}

\section{La Contrarrevolución: un corte profundo en nuestra historia}

Estamos a punto de iniciar la sesión 13 de nuestro recorrido por la historia de la mano de Esperanza. Saluda a las niñas, motívalas para que sigan con atención y entusiasmo la última etapa de este proceso. Mientras llegan, salúdalas amistosamente y cuéntales qué tal ha estado tu semana.

\section{Hagamos memoria}

¿Recuerdan que al final de la sesión anterior compartimos un problema matemático que debían resolver durante la semana en casa? Pregúntales qué tal les fue, y resuélvelo con ellas.

Dijimos que en la comunidad habían 3 terratenientes y 97 campesinos.

Los 3 terratenientes eran dueños de 70 parcelas. ¿̇Cuántas parcelas tiene cada uno de ellos?

$$
70 / 3=23.33 \text { parcelas por terrateniente. }
$$

Luego, entre los 97 campesinos, poseen las 30 parcelas restantes de la comunidad. ¿Cuántas les corresponden a cada uno de los campesinos?

$$
30 / 97=0.31 \text { parcelas por campesino. }
$$

Reflexionen juntas:

- ¿̇ué piensan de los resultados?

- ¿̇Será justa esa distribución?

- ¿A los campesinos les alcanza lo que tienen para vivir tranquilos?

- ¿QQué hacen los terratenientes con el exceso de tierras que poseen?

\section{Nuestras grandes preguntas}

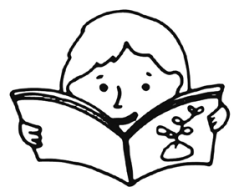

Hay momentos de la historia que parecen no tener relación directa con nuestras vidas. Sin embargo, son tan importantes para el desarrollo de la comunidad que integramos, que tienen un impacto en nuestro día a día. ¿¿Qué momentos serán?

$$
\text { Guia para mentoras de Abriendo Oportunidades }{ }^{(3)}
$$


Pregúntale a las niñas si se les ocurre algún momento o algún acontecimiento importante que ellas hayan vivido y que se recordará mucho en el futuro de la comunidad. Platiquen al respecto, y pongan en común su experiencia.

\section{Los relatos de Esperanza}

Hoy conoceremos junto a Esperanza uno de los acontecimientos más tristes y dolorosos de la historia guatemalteca del siglo XX. Se trata de un golpe que aún tiene consecuencias para nuestra vida, y que debemos conocer a profundidad para poder hacer algo y enfrentar sus efectos. Escuchemos con atención el relato:

\section{Cuando cortaron la Revolución}

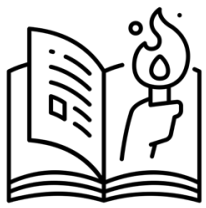

-Cada vez que te veo preparar el suelo y miro las semillitas antes de ser cubiertas por un poco de tierra, siento que lo que va a venir tiene que ser bueno. Me imagino las criaturas adentro de sus mamás. Cuántos días nuevos, cuántas ideas, cuántas cosas que van a venir a pensar... Eso debe ser la esperanza, żverdad?

-Tan chulo eso que decís, Feliciana. Ojalá así sea y que esto sólo crezca. Si la vida no se trata sólo de sufrir y cansarse y ser maltratados. Aunque te digo que a veces me da miedo. Se oyen cosas...

Así hablaban Macario y Feliciana. Es que eso de la Reforma Agraria había sido un cambio muy drástico. Nunca había pasado una cosa parecida hasta entonces, porque siempre las condiciones habían sido más o menos las mismas para la gente del campo: trabajo durísimo que apenas les permitía sobrevivir en las tierras que eran propiedad de gente que nunca habían visto, que estaban lejos pero que hacían sentir su poder a través de los capataces, a través del hambre, a través de las inmensas diferencias.

Pero esa reforma les había ayudado como nada lo había hecho antes. Feliciana y Macario trabajaron mucho para organizar a la gente, para ubicar las tierras que nadie usaban aunque tuvieran dueño. La UFCO, la "yunait fruit compani", ese era el nombre de los dueños de la tierra, que la poseían aunque no la sembraran. Por eso, los campesinos trabajaron junto al gobierno para poder usar mejor los recursos, para calmar su hambre.

Pero los gringos, la ley y el dinero se sentían amenazados y ya les habían llegado avisos. De hecho, días antes lanzaron desde el aire unos volantes que decían "Liberemos a Guatemala del comunismo, fuera Árbenz". Macario estaba una tarde en Cobán porque fue a rendir informes sobre su trabajo como agrarista, y un hombre en el mercado se le acercó por la espalda y le dijo:

-Macario, si no dejás de trabajar para los comunistas te van a matar. Ya van a botar al Presidente y nadie va a protegerlo. Mejor dejá de trabajar para ellos, esa tierra no es de ustedes.

Macario sintió un miedo que le secó la boca, que le hizo sudar frío. Ni siquiera vio bien al hombre, porque cuando se volteó ya iba saliendo del mercado y sólo le vio la espalda. 
Apenas pudo distinguir que llevaba un machete colgado de la cintura.

No le quiso contar a Feliciana lo que le había pasado, no ese día. Ella estaba tan contenta de ver las matitas de su siembra en la tierra nueva, que no quiso compartirle su miedo. No podía ser cierto. "¿Cómo van a tirar al Presidente Árbenz, si tanta gente que está con él, si es la única vez que ha pasado algo bueno para los pueblos, para la gente campesina", pensaba Macario.

Pero las cosas raras seguían pasando: tiraban papeles, les decían comunistas, se oían voces que de repente interrumpían la marimba de la radio y decían que había que liberar a Guatemala del comunismo, que había que sacar a Árbenz. Feliciana fue cambiando su alegría por preocupación. Tuvieron que hablar, y Macario le contó de las amenazas directas, porque la verdad es que ella ya se había dado cuenta de los papeles, de lo que decía la radio.

-Fijate que yo ni sé qué es eso de comunismo. Creo que nadie sabe bien qué es eso. Pero nada malo había pasado hasta ahora, que hay gente que nos empieza a ver con desconfianza. Macario, yo creo que los dueños de la Frutera se están inventando eso, quiera que no sintieron que les quitaron algo. Como que supieran ellos qué es el hambre, qué es el cansancio, como que supieran qué es que le quiten a uno la vida.

La tarde del sábado, Macario le dijo a Feliciana que fueran con los niños a hablar con el fuego, que sentía la necesidad de hacerlo. Subieron al pequeño cerro que está detrás de su casa y prepararon las candelas, el copal, el pom, el azúcar. "Hoy es día para pedir sabiduría, es día que vamos a pedir que nuestra columna esté recta para dejar pasar los buenos pensamientos", les dijo Macario. El pequeño Lix se quedaba quieto al ver que el fuego se trenzaba, se extendía, casi lo oía decir palabras, con atención escuchó lo que el fuego le decía: "El sol de mañana trae filo, van a cortar hilos pero guarden los suyos, escondan sus hilos, que nos los corten, cuídense, porque el nuevo sol va a cortar con el filo de la piedra del rayo..."

Lix, que en esos días tenía nueve años, se puso a llorar. Feliciana asustada lo abrazó, y sin preguntarle por qué lloraba también miraba el fuego, y atrás del fuego los cerros, y la luz del día Noj que les había dicho que se prepararan.

La noche del domingo 27 de junio de 1954, día Jun Tijax, Feliciana y Macario se acostaron después de arreglar las tareas de leña afuera de la casa, desgranar el maíz y escoger el frijol. Macario estaba haciendo listas de personas que necesitaban tierra y que se acercaron al comité agrario. Feliciana estaba arreglando su pimienta, su ruda, su canela y sus brazas, porque estaba esperando que la llamaran para atender el parto de su comadre Flor. Después de un rato ya no había luz, y todos dormían en la pequeña casa pegada al cerro. La noche era un ojo cerrado. Todos soñaban.

Con urgencia sonaron en la puerta los golpes que los despertaron. Era tal vez media noche. Feliciana debía salir corriendo porque era el momento de que Flor se compusiera. Se asustaron mucho con el sonido. Macario sintió un susto que le llegó de los pies a la cabeza. Salió a la puerta a ver a Feliciana hasta que ella se perdió en el camino con su bracero listo para recibir a la criatura.

Intranquilo, Macario encendió el radio, buscó alguna señal que estuviera abierta, ya que era muy tarde para escuchar algún programa. De pronto, escuchó las noticias en cadena nacional: "Bajo la presión de una invasión por parte de los Estados Unidos y con

$$
\text { Guia para mentoras de Abriendo Oportunidades }{ }^{(3)}
$$


el objetivo de mantener a salvo los logros de la Revolución de Octubre, Jacobo Árbenz Guzmán renunció a la presidencia de la República".

"No. Eso no puede ser, la vida está empezando. No. Las amenazas de la caída no pueden ser ciertas, tiene que pasar algo más, seguro no se va a retirar. $\dot{\imath} Y$ si es cierto que estamos en peligro? ¿̇Y si no podemos mantener esto? El hombre en el mercado, los volantes, la gente que nos ve mal. No. No". Macario sintió frío en todo el cuerpo, buscaba una emisora que aclarara que las cosas no eran así, que la Reforma Agraria estaba a salvo, que Árbenz seguía siendo presidente. Y con la radio en las manos, viendo la imagen de sus tres niños dormidos, lo aceptó: tenía miedo. Mucho miedo.

Feliciana regresó antes del amanecer, cuando los gallos ya estaban cantando.

-El Coronel ya no es Presidente.

Feliciana abrió los ojos del susto, tragó saliva, se limpió la cara con su pañuelo y se sentó.

-Flor tuvo una nena. Linda la criatura, nació con los ojos muy abiertos.

-Que nazcan las criaturas en la noche es una señal de que debemos mantener la esperanza despierta. Esto no se puede caer así nomás.

Mientras la luz iba poco a poco sacando la casa de las tinieblas, Feliciana y Macario se quedaron en silencio, pensando qué iba a pasar ahora.

Esperanza y su abuelo habían ido a la Gobernación de Cobán. El asunto del río estaba avanzando, pero las gentes que cuidaban las siembras de palma estaba intimidándolos mucho. Sentían miedo de ser atacados y por eso tenían que ir a la cabecera departamental para pedir ayuda.

Esperanza esperó a su abuelo en el parque que está justo atrás de la Gobernación. Le gusta sentarse ahí, ponerse a pensar, a imaginar cosas mientras su abuelo está ocupado. Cuando don Lix regresó, Esperanza hacía equilibrios en la orilla de un arriate.

-Me trajiste recuerdos, mija. Así cabal como estás jugando ahorita me ponía yo cuando mi mamá nos traía a buscar a mi papá.

- ¿Cómo así a buscar a su papá, abuelito?

-Es que mi papá estuvo preso varios meses. Cuando cayó el presidente Árbenz lo agarraron a él, a otros de sus compañeros. Fue espantoso. Yo apenas tenía nueve años, pero recuerdo el llanto de mi mamá, recuerdo la intimidación, el miedo.

-¿¿Pero sí lo encontraron?

-Sí. Aquí lo tenían encerrado en Cobán, pero además lo lastimaron. Todos los días lo golpeaban, le decían traidor, le decían de todo. Cuando salió de la cárcel ya no era el mismo, le apagaron su luz de sus ojos. La caída de Árbenz no fue sólo de Árbenz, fue la caída de Guatemala. Y así como mi papá, mucha gente se quedó rota, triste.

-¿¿Qué pasó con la Revolución, Tata Lix?

-La tiraron, mijita. Los gringos pusieron a su Presidente, hicieron todo para regresar a la Guatemala de antes. Por suerte, los presidentes de la Revolución hicieron bastante en sólo 10 años, tanto que la verdad todavía se ven los logros de esos años. Pero el golpe que nos dieron fue terrible, mija. A veces creo que todos lo sentimos aquí, en el pecho, 
como que tenemos memoria de esos años en los que empezaba a crecer el país como una milpita, pero vino el machetazo de la contrarrevolución y todavía nos duele.

- ¿ Pero la gente no trató de hacer otra Revolución, Tata Lix?

-Sí, mija, si algo no ha dejado de hacer la gente aquí es luchar. Yo por eso vengo a luchar por ese río, por la memoria de mis papás, de Feliciana y Macario, gente que trabajó con la esperanza de una tierra más buena para todos. Y en mi mente yo les hablo, Nana Feliciana, Tata Macario: sepan que la Revolución de Octubre, tal vez con otro nombre y otras formas sigue viva, está creciendo, está bien.

Comenten el cuento. ¿̇Notaron que en medio de un momento muy difícil para toda la comunidad nació una pequeña niña? ¿QQué significará su nacimiento?

\section{Recuerda tener claro que:}

1. La contrarrevolución es un acontecimiento fundamental para entender la historia reciente de Guatemala. El 27 de junio de 1954, por las presiones que recibía de todos lados, el presidente Jacobo Árbenz renunció a su cargo. Con esto, quería evitar un ataque directo de los Estados Unidos y que se mantuvieran los logros más importantes de la Revolución de Octubre.

2. Los principales factores que lo llevaron a renunciar fueron los intereses extranjeros, principalmente de la compañía frutera (mayor terrateniente del país en ese entonces) y del gobierno norteamericano. También se sumaron sectores importantes de la sociedad guatemalteca, que traicionaron los ideales de bienestar popular que Árbenz defendió. Entre ellos destaca el arzobispo Mariano Rossell y Arellano, el ejército guatemalteco y los terratenientes locales, todos miembros de los grupos de poder tradicional.

3. Con la caída de Árbenz, no solo cayó él y su gobierno, sino el proyecto revolucionario guatemalteco: los grandes programas, principalmente enfocados en ampliar los derechos para los ciudadanos y ciudadanas guatemaltecas, se interrumpieron y se quisieron anular los logros de la revolución. Muchas persona fueron perseguidas, violentadas e incluso asesinadas durante la Contrarrevolución.

¿Cómo se vivió este proceso en nuestras comunidades? Consúltalo con tus amigas mentoras o con la gente mayor de la comunidad, e investiga en internet.

Como un material de apoyo que te ayudará a recordar detalles sobre la Revolución de Octubre y sobre la caída de Árbenz, te sugerimos ver este pequeño documental, que se llama "Revolución de Guatemala":

https://www.youtube.com/watch? $v=4 \mathrm{k} 3 \mathrm{RNfpPFfc}$ documental animado 


\section{Hagamos algo juntas}

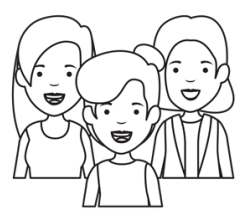

Hoy pensaremos en un bosque. A pesar del momento triste que acabamos de conocer sobre el pasado de nuestro país, iremos a un espacio cómodo, seguro, que esté lleno de árboles y plantas. Si puede ser un bosque cercano al lugar de la sesión, sería ideal. Si no, un jardín o un parque funcionarán.

Pídele a las niñas que se ubiquen formando un círculo y pídeles que vean con atención a su alrededor. Que piensen en un bosque. ¿¿Qué elementos integran el bosque? Trata de que enumeren las plantas, los animales, todo lo que conforma un bosque, de acuerdo a su experiencia con el entorno. Hazles notar la riqueza y la variedad de formas de vida que integran ese bosque que estamos pensando. Pídeles que piensen en la riqueza de la vida natural cuando se le permite crecer libremente.

Ahora, pregúntales si han visto procesos de siembras y monocultivos que hayan destruido bosques cercanos a la comunidad. Reflexionen sobre el daño que hace la tala y la destrucción de los árboles, de las fuentes de agua, de los animales que habitan el bosque.

Comparte con ellas esta reflexión:

La Revolución de Octubre hizo posible un bosque como el que estamos imaginando. Muchas formas de vida, muchas personas

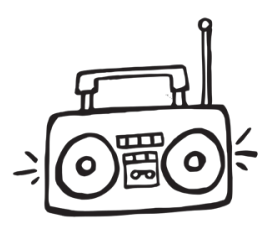
distintas, empezaron a construir juntos un nuevo proyecto de país. La Contrarrevolución quiso acabar con ese bosque. Fue muy violenta, y destruyó mucho de lo que se había sembrado en los 10 años de Revolución. Sin embargo, la vida es fuerte y nuestras comunidades también. Al poco tiempo, empezaron a reponerse poco a poco del golpe de 1954. Lo que hoy somos tiene relación directa con ese y otros momentos de la historia. Y debemos tener claro eso, para explicarnos por qué estamos como estamos.

\section{Oportunidades en casa}

Durante las últimas tres semanas hemos estado platicando sobre la Revolución de Octubre de 1944, y sobre su caída 10 años después. Durante la semana, traten de hacer memoria y elaboren dibujos sobre lo que aprendimos con Esperanza sobre la Revolución, sobre Juan José Arévalo, sobre Jacobo Árbenz. Sus dibujos serán el testimonio de lo que hemos aprendido juntas. Traten de hacer la mayor cantidad posible, y al inicio de la próxima sesión, compartan sus dibujos con sus compañeras. 


\section{Las palabras que nos nombran}

Hace muchos años, un poeta llamado Otto René Castillo escribió este poema:

$$
\begin{aligned}
& \text { "Nada } \\
& \text { podrá } \\
& \text { contra la vida, } \\
& \text { porque nada } \\
& \text { pudo } \\
& \text { jamás } \\
& \text { contra la vida". }
\end{aligned}
$$

Reflexionen sobre el poema. Recuerden el bosque que acabamos de pensar. ¿¿ué podemos hacer nosotras para ayudar a la vida a florecer de nuevo?

\section{Ruta hacia un proyecto comunitario}

¿Cómo va nuestro proyecto comunitario? Antes de concluir la sesión, consúltale a las niñas qué tal van las tareas que tienen asignadas para su proyecto comunitario. Las semanas siguen avanzando, y debemos completar nuestro compromiso con nosotras, con nuestras compañeras y con nuestra comunidad. Apóyalas en lo que sea necesario, y pídeles que no olviden lo que deben hacer.

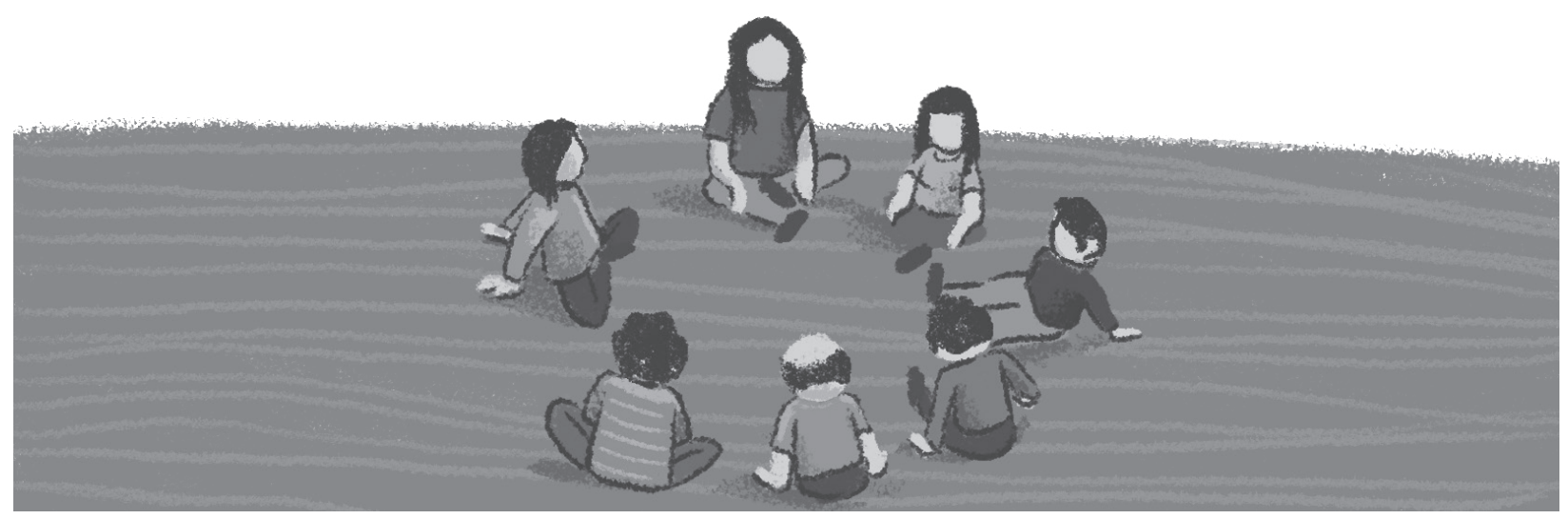




\title{
Sesión 14
}

\author{
El inicio del Gran Problema
}

\section{Hagamos memoria}

Dale la bienvenida a todas las participantes. Platiquen sobre cómo estuvo su semana. Recuérdale a las niñas que al finalizar la sesión anterior, les pediste que hicieran memoria y a partir de lo aprendido en las últimas sesiones elaboraran dibujos sobre la Revolución de Octubre. Pídele a las niñas que le muestren sus dibujos a sus compañeras, y que a través de ellos traten de recordar detalles de ese momento importante de la historia guatemalteca.

\section{Nuestras grandes preguntas}

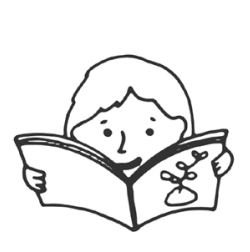

¿Recuerdan lo que hablamos en la sesión anterior sobre cómo terminó la década revolucionaria en Guatemala? ¿Recuerdan la palabra "contrarrevolución"? Trata de refrescar la memoria de las participantes, recordándoles el proceso traumático que como sociedad vivimos en 1954. Reflexionen juntas sobre las siguientes preguntas:

- ¿Cómo reacciona cada una de nosotras cuando nos sucede algo triste?

- ¿Cómo nos curamos el susto?

- ¿QQué debemos hacer cuando a la comunidad de la que formamos parte le sucede algo malo?

\section{Los relatos de Esperanza}

Hoy empezaremos a hablar sobre una época muy difícil de nuestra historia. Los pueblos originarios la conocen como "El Gran Problema", y también se le menciona como el "Conflicto Armado Interno". Fue una época dura, que empezó justo después de la caída de la Revolución, y terminó hasta 1996. Acompañemos a Esperanza a conocer un poco más sobre la historia reciente de nuestro país:

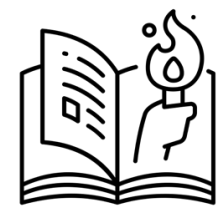

\section{Debemos parecernos más a la vida}

La lucha por el río ha sido intensa. Todos en la comunidad de Esperanza han sentido enojo y rabia, porque es injusto lo que hacen con al agua del río, porque es injusto que la propiedad de la tierra sea capaz de 
dejar a comunidades enteras sin agua, sin caminos. Desde que llegaron las plantaciones, los árboles cada vez son menos y con ellos los pájaros, las semillas, los frutos, la sombra y los animales. "No deberían existir las propiedades", piensa Esperanza, "no debería ser permitido tener tanto poder a costa del sufrimiento de otra gente, de animales inocentes, de árboles y flores. Es demasiado lo que se da a cambio de ponerle precio a la tierra".

Pero además del enojo, la gente de la comunidad también se ha sentido fuerte cuando están todos juntos. Ha sido una lucha incansable, con mucha gente que ha decidido defender no su propiedad, sino la vida. Poco a poco han ido logrando que el río vuelva a su cauce, primero como un arroyo que luego va ensanchándose. El río vuelve y con esto la esperanza en la vida buena también. Por eso han decidido organizarse de mejor forma. En las reuniones que tienen todas las semanas en el salón comunal, llegaron a la conclusión que necesitaban mantenerse fuertes para resistir la invasión de los palmeros y para enfrentar las necesidades económicas que todos tienen. Por eso, decidieron fundar juntos una cooperativa.

Y en esta cooperativa van a intercambiar y a veces a vender lo que cada persona produce. Esperanza estaba muy feliz de ver a sus amigas con los productos de sus huertos. Ella misma estaba ahí con lo que había cosechado, su abuelo con sus cajitas, don Gil con chile cahabonero, Quetzalí y sus amigas mentoras con los huevos que producían las gallinas que hace un tiempo lograron comprar, doña Berta con su cardamomo. La idea era que la comunidad no tuviera que comprar productos de fuera y que los precios sean siempre accesibles, pero también salir a otro lugares a intercambiar lo que juntos producen.

Con el tiempo, vieron que necesitaban fortalecer muchas cosas en la cooperativa, y gracias a doña Berta-amiga de su abuelo- se empezaron a hacer los Círculos de la Memoria. ¿¿Qué eran esos círculos? Doña Berta pensaba que era necesario contar su pasado para que los más jóvenes supieran el camino de su comunidad. Entonces, se le ocurrió hacer reuniones cada cierto tiempo para que se contaran historias, para que cada uno pudiera contar su experiencia, su vida. Esos círculos fueron una puerta más para Esperanza: una puerta que se abría y le contaba algo que tenía mucho que ver con su presente.

Así, cada vez que se reunían en el Círculo de la Memoria, se hacía un recuento de la historia de cada persona, y eso lo iban acompañando de los hechos más importantes de la historia del lugar, del municipio, del país. Los mayores contaron sus memorias más lejanas y eso lo reunían con las memorias de otros que ya no estaban aquí, entre nosotros. Gracias a ese ejercicio, Esperanza se enteró de lo que pasó después que cayera el gobierno revolucionario de Jacobo Árbenz Guzmán.

-Allá lejos me recuerdo yo de cuando cayó Árbenz. Mi papá tuvo que devolver la tierra. Apenas estaban brotando las matitas de su siembra, estaban tiernitas cuando llegaron los del "Gobierno de la Liberación" a sacarnos, pues decían que eso no era de nosotros, que era de la UFCO. Yo pues apenas entendía, pero ay dios mi papaíto, que en paz descanse, cuánto le dolió, y a todos nos dolió, pues en la casa teníamos ya mejores días y nos los quitaron -decía Doña Berta.

$$
\text { Giva para mentoras de Abriendo Oportunidades }{ }^{\circledR}
$$


-Por eso fue que el hambre volvió a pegar duro. Había mucha gente indignada, desesperada. Y a los pocos años ya se escuchaba que había un movimiento que iba a hacer otra revolución, allá en el oriente por la Sierra de las minas -decía don Gil.

-Es que eso sí hay que tenerlo muy claro: la gente nunca dejó de organizarse, nunca lo ha dejado de hacer. Al tiempo supimos que había gente en occidente también, que empezaban a ver cómo se recuperaba lo que les habían quitado, porque qué diferencia eso de haber tenido nuestras tierras y luego volver a esa miseria. Es que uno decía: "De dónde vamos a sacar el futuro con esta hambre". Ah, pero siempre ha habido gente decidida. Me acuerdo yo que un muchacho dijo un día que si habían grupos de gente que querían recuperar el poder, nuestro lugar era con ellos no con las fuerzas del gobierno, porque el gobierno este era igualito que los de antes, no como los de la Revolución, que esos si fueron otra cosa -decía don Lix.

Esperanza entendió entonces que una revolución puede nacer de algo chiquito, que en esos años en Guatemala -en distintas partes del país- habían hombres y mujeres organizando la rabia, la cólera, para empezar de nuevo el camino hacia lo que les habían quitado. La Revolución del 44 había sido grande. Los poderes de siempre la tiraron, pero cuando cayó al piso se hizo pedazos y esos pedazos se volvieron luchas, se hicieron organizaciones regadas por distintos lugares del territorio.

Al final de su participación, don Gil dijo:

-Fue entonces que vino el Gran Problema, porque siempre que se busca que la gente deje de pasar hambre, que se le dé su lugar, vienen los de hasta arriba y tiran a matar... así empezaron otros dolores, otros sufrimientos.

-Pero lo que yo quiero es que las patojas y los patojos sepan esto, porque ahora es otro tipo de lucha pero contra los mismos males. Y si una lección nos dio a nosotros ese Gran Problema es que las luchas chiquitas de un montón de lugares se tienen que organizar y hacerse una sola, grandota, porque así sí calculo yo que somos más grandes que los que nos quitan tierras, agua y vida... -dijo doña Berta.

Esperanza sentía que se le alborotaba algo en el estómago cuando pidió la palabra. Le latía fuerte el corazón como un tambor, pero igual quería hablar. Levantó su mano, y uno de los señores le dio la palabra:

-Yo creo que la lucha por nuestro río fue una prueba grande, pero no ha sido lo más grande que vamos a lograr, porque la palma todavía está aquí y se trata de que la vida vuelva al plan original: al de la diversidad, la fuerza y la autonomía. Por eso esta cooperativa debe parecerse más a la vida, y no a los que nos quitan el río y las tierras para sembrar. Vamos a ser diferentes, con productos diferentes, pero juntos, como la vida misma.

Todos le aplaudieron a Esperanza, y ella todavía temblorosa y con la cara roja, sintió que tenía más claro el rumbo que había que tomar, porque ha sido mucho sufrimiento el de su comunidad -y el del país entero-, pero también han sido muchas las lecciones que ha dejado el pasado y todos las tenemos que poner en práctica.

Reflexionen juntas: ¿̇ué piensan del cuento que acabamos de escuchar? ¿̇Han sabido de alguna iniciativa parecida a los Círculos de la Memoria? ¿En su casa se habla de estas cosas? 


\section{Recuerda tener claro que:}

1. El origen del conflicto armado interno en Guatemala está muy relacionado con el cierre de opciones políticas de participación luego de la caída del presidente Árbenz.

2. La violencia desde el Estado hizo que muchas personas se decidieran por la lucha armada para cambiar las estructuras injustas del país.

3. Entre 1960 (año en que se da el primer alzamiento militar en contra del gobierno guatemalteco) hasta 1996, una serie de personas e instituciones se fueron sumando a la lucha, aportando desde sus espacios y sus capacidades, con la idea de buscar un país más justo para todas y todos. Esa lucha común fue reprimida con violencia desde las instituciones de gobierno.

\section{Hagamos algo juntas}

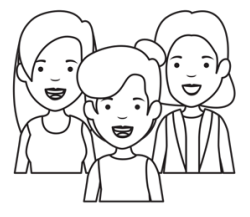

Con esta actividad pondremos en práctica una enseñanza que nos deja el Círculo de la Memoria del cuento que acabamos de escuchar: nuestras luchas se complementan y se apoyan unas a otras.

Comparte con las niñas las siguientes instrucciones:

1. Busquen un árbol frutal cercano al lugar donde se reúnen (si no hubiera un árbol frutal, trata de identificar alguna planta que produzca alimento, algún cultivo).

2. Colóquense en grupo a cierta distancia del árbol, y tomémonos todas de la mano.

3. Una de nosotras no podrá moverse de este punto, y tampoco nos podremos soltar. Pensemos juntas: ¿Cómo alcanzar el árbol sin soltarnos?

El grupo tendrá que encontrar la forma de coordinar sus movimientos para alcanzar el árbol, pero una niña no podrá moverse del punto de partida. La idea es que tracen una cadena, o una línea que les permita alcanzar el objetivo común, partiendo del lugar en que todas iniciaron.

Cuando lo alcancen, reflexiona con ellas sobre la necesidad de pensar juntas la mejor salida para nuestros problemas. Haz que noten cómo podemos tener mejores resultados si cada una aporta sus capacidades y sus talentos para enfrentar juntas los problemas que nos afectan.

\section{Oportunidades en casa}

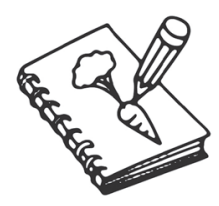

Antes de despedir esta sesión, pídele a las niñas que le pregunten a sus padres, a sus familiares mayores en casa, si saben algo del Gran Problema. ¿̇ivieron ellos el conflicto armado? ¿Lo recuerdan? Muchas veces no hablamos en nuestra casa de las cosas que hemos vivido en

$$
\text { Guia para mentoras de Abriendo Oportunidades }{ }^{(3)}
$$


el pasado. Por eso, es importante platicar. Índicale a las niñas que si sus papás preguntan por qué se están hablando estos temas, que les expliquen que la intención es conocer mejor la historia de la comunidad y de la familia. No se trata de recordar lo malo, lo violento o lo feo, sino cómo ha sido la vida en nuestros territorios.

Pídeles que anoten las respuestas de sus familiares, o que elaboren dibujos al respecto, a fin de que no se les olviden. Al inicio de la próxima sesión, todas compartiremos nuestra experiencia de trabajo en casa. 


\section{Sesión 15}

\section{La cumbre del Gran Problema}

Estamos acercándonos al presente, en nuestro recorrido por la historia de los territorios y las comunidades de Guatemala. Saluda a las niñas, conversa con ellas. ¿̇Qué sienten de toda esta experiencia de las últimas semanas? Resuelve sus dudas, comparte las tuyas, y gocen la posibilidad de aprender juntas.

\section{Hagamos memoria}

Para iniciar esta sesión, pondremos en común cómo vivieron nuestros familiares el Gran Problema. Pregúntales: ¿¿Qué resultados obtuvieron platicando respecto al conflicto armado interno en sus casas? ¿Pudieron obtener respuestas de sus familiares durante la semana?

\section{Nuestras grandes preguntas}

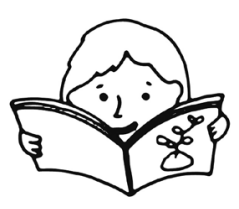

Muchas veces sentimos que los grandes temas históricos no tienen relación con nuestra propia vida. Sin embargo, las decisiones, los procesos, las luchas de nuestras comunidades determinan mucho de nuestro día a día, aunque no lo sepamos. Por eso, vale la pena preguntarnos:

- ¿Cómo se vivió el conflicto armado interno en nuestra comunidad?

- ¿QQué pasó aquí, en el lugar que habitamos, durante los años del Gran Problema?

Realiza una investigación en internet y platica con los ancianos de la comunidad para tener más y mejor información. Comparte tus hallazgos con las niñas durante esta sesión.

\section{Los relatos de Esperanza}

Hoy Esperanza conocerá una historia que la acompañará en su futuro. Es una historia dolorosa, pero a ella le dará mucha fuerza. Escuchemos con atención cómo las preguntas que nos hacemos en el presente son flores para ofrendar a la memoria de quienes han estado antes que nosotros: 


\section{Nuestras preguntas son flores}

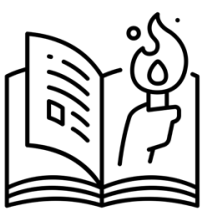

Cuando terminó la reunión de la cooperativa, Esperanza se quedó ayudando a Quetzalí, pues tenía que dejar el salón listo para el grupo de Abriendo Oportunidades que ocupaba el salón comunal todos los sábados. Mientras arreglaban todo, empezaron a platicar:

-Quetzalí, ¿̇tú sabías todo eso que pasó antes y que contaron hoy los viejitos?

-Sí, pero no siempre lo supe, porque a veces la gente prefiere callar lo que le ha causado más dolor. Eso no es bueno, pero también se entiende, porque una experiencia tan dura como el Gran Problema deja mucha tristeza.

- ¿̇El Gran Problema fue una guerra? -preguntó Esperanza.

-Pues digamos que sí. El Gran Problema fue un conflicto entre dos grupos: el ejército y la guerrilla. Los dos cometieron violaciones de derechos, pero la verdad es que el ejército mató muchísima gente sin razón, o por lo menos no con las razones que decían. Acá hay mucha gente que tiene memorias de la guerra, gente que no era de aquí pero que decidió moverse de su pueblo porque hubo alguna matanza.

Esa palabra -matanza- le puso frío el cuerpo a Esperanza.

"Matanza", repetía en su mente, y casi podía escuchar gritos y disparos. Sentía el corazón palpitando fuerte y algo como una angustia que la invadía. Quetzalí seguía ordenando las sillas, pero pudo notar la pena de Esperanza.

La niña volvió a preguntar:

- ¿̇Y conocés gente a la que le haya pasado algo en la guerra?

-Pues sí. Yo por ejemplo sé de mi tía María Luisa, que le mataron a su esposo en Panzós. Y también al pobre don Gil... Fue bien feo lo que le pasó.

Esperanza sabía que su abuelita Cándida había muerto cuando su mamá era bien chiquita. Supuso que algo tenía que ver la guerra con eso, porque la habían matado y su cuerpo estaba enterrado con más personas, pero su abuelito se ponía muy triste cuando salía el tema en alguna conversación. Además, su mamá casi no había vivido con ella porque tuvo que irse a trabajar a Estados Unidos, entonces realmente sabía muy poco de su abuela.

- ¿̇erá que a mi abuelita Cándida la mataron en la guerra?

-No soy yo quien te puede responder eso, Esperancita -le dijo su mentora-. ¿¿Qué te dice el corazón?

Poniéndose las manos en el pecho, Esperanza cerró sus ojos y vio el rostro de su abuela. Estaba llorando y abrazaba a su pequeña nenita, protegiéndola...

-Creo que sí.

-Es muy probable que así haya sido, pero ¿̇sabés una cosa? La gente que murió injustamente en la guerra florece en las preguntas de sus hijas, de sus nietas. Tu pegunta es una flor que nace de la memoria de tu abuela, Esperancita.

- ¿̇ esa guerra qué era lo que buscaba? ¿̇A quién estaba defendiendo?

-Aquí la gente se estaba defendiendo a sí misma, a la tierra, al agua, como siempre. Por otro lado, el ejército estaba defendiendo los intereses de los más ricos, de los que más tienen y no les basta, de los que le quieren quitar todo a la gente con tal de que su poder 
crezca más...

Esperanza sintió el enojo de Quetzalí. Vio que sus ojos querían llorar y su boca quería gritar. La abrazó entonces.

-Esto no va a ser siempre así, Quetzalí. Yo a veces escucho en mi cabeza cosas que pienso pero con voces que no conozco, y son muchas. Hablan todas juntas. ¿̇Y sabés qué pienso? Que son voces del futuro y del pasado que nos vienen a decir qué hacer.

Quetzalí se le quedó viendo y le dijo:

-Tenés algo, Esperanza: tenés imaginación y preguntas. Esas son dos grandes herramientas para hacer camino. Hay que ser valientes, hay que ser decididas, hay que pensar por el bien de toda la gente, de todos los árboles, de todos los ríos. Te voy a contar una historia: la historia de Mamá Maquín, una mujer que luchó por nuestra tierra, una defensora que amó su tierra y que la cuidó hasta las últimas consecuencias.

La niña y su mentora se sentaron en medio del salón, y Quetzalí le contó la historia de una mujer maya $Q^{\prime}$ eqchi', como ellas, que defendió a la tierra, el agua y a la vida misma. Se llamaba Adelina Caal, pero toda la gente le decía Mamá Maquín, quizá porque su forma de cuidar la tierra era tan fuerte y tan amorosa como el cuidado que le ponen las mamás a sus criaturas.

-Ella es un símbolo de todas las luchas que hemos tenido acá, de todas nuestras resistencias.

-¿̇Y todavía está viva?

-No. Y no está viva porque el ejército -junto con el alcalde de ese momento- dieron la orden de disparar cuando iba al frente de una manifestación. Tenía 67 años y se había dedicado a cuidar la vida, y para los que quieren tener tierra y poder, una persona como Mamá Maquín es una enemiga. Pero su memoria florece cuando nosotras defendemos lo mismo que ella defendió, porque cuando alguien ama la vida y la cuida, con su muerte se hace árbol, aire, agua, recuerdo, presencia. La gente que la mató tendrá poder, pero no es el símbolo, no es la guía.

Esperanza lloró, Iloró mucho al oír la historia de Mamá Maquín. Se abrazó a Quetzalí, pensó en la gente y sus dolores, en la memoria de la gente que amó y que murió en la guerra. Lloró por su abuelita Cándida, por la tristeza de su abuelo Lix, por la ausencia de su mamá que tuvo una vida difícil, tan difícil que debió salir a una tierra lejana a buscar un camino. Y entre el llanto pensó en Mamá Maquín. "Le prometo seguir su lucha y defender la vida y los territorios $Q^{\prime}$ eqchi' siempre, hasta que la dignidad regrese, hasta que todos estemos felices y contentos", pensó Esperanza, en medio de ese salón en el que habían resonado las historias tristes de los mayores, y en el que unas horas después se reunirían ella y las demás niñas para pensar, sentir y aprender juntas las formas de abrir nuevas oportunidades.

Pregúntale a las niñas: ¿Habían escuchado alguna vez la historia de Mamá Maquín? ¿Qué les hizo sentir lo que vivió Esperanza en este relato? 


\section{Recuerda tener claro que:}

1. La masacre de Panzós fue uno de los acontecimientos violentos más conocidos de los años 70. Sucedió el 29 de mayo de 1978, cuando un grupo de personas Q'eqchi' protestaron por los abusos de las empresas transnacionales y de los terratenientes locales en el valle del Polochic. El ejército disparó contra las personas y mató a más de cuarenta. Entre ellas estaba Mamá Maquín, símbolo de la lucha de las mujeres mayas en defensa de sus territorios.

2. Los años más violentos del conflicto armado interno en Guatemala abarcan de 1978 a 1983, cuando fueron jefes del Estado de Guatemala los militares Romeo Lucas García y Efraín Ríos Montt. En esos años se cometió la mayoría de masacres en distintas regiones del país, y muchísimas personas murieron, fueron desaparecidas o tuvieron que migrar.

\section{Hagamos algo juntas}

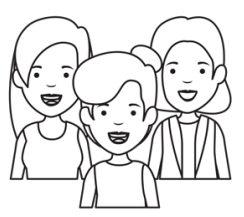

Para esta actividad, trata de conseguir alguna forma de que las niñas puedan ver este video. Puedes utilizar una pantalla, un proyector, o tu celular. Si resulta imposible, al menos es importante que puedan escuchar claramente la letra de la canción.

Hoy veremos "La llorona de los cafetales", una película de Jayro Bustamante, sobre una canción que canta Gaby Moreno. La encontrarás en el siguiente enlace:

https://www.youtube.com/watch?v=9FL7GmbNzK4

Luego de ver la película y escuchar con atención la letra de la canción, reflexionen juntas sobre lo que les hace sentir.

- ¿̇Tiene alguna relación con algo que hayamos sentido en carne propia?

- ¿Podemos identificarnos con algo de lo que dice la letra de canción?

\section{Las palabras que nos nombran}

Hoy conoceremos un poema de Sabino Esteban Francisco, un poeta maya Q'anjob'al que ahora vive en Ixcán, Quiché. No tiene aún 40 años, pero vivió en carne propia el Gran Problema, y lo recuerda así: 


\section{Otra vida \\ Sabino Esteban Francisco}

Después del bombardeo

resurgía la voz de las aves.

Como fuente dulce,

alegre, hecha canto de vida.

Desde la trinchera

germinaban nuestras risas.

Y salíamos

con retazos de carbón

y pedazos de tabla

a pintar otra vida

en el dorso de esa vida.

Pregúntale a las niñas: ¿̇Qué sensación les deja el poema? ¿Puede haber esperanza después de haber pasado por una experiencia triste y dolorosa? Reflexiona con ellas sobre la posibilidad que nos otorga la vida de trascender las experiencias tristes para sacar de ellas la fuerza necesaria para buscar otra vida, una vida mejor para todas.

\section{Ruta hacia un proyecto comunitario}

Estamos a pocas semanas de terminar nuestro proceso de aprendizaje. Por eso, debemos ir cerrando las tareas pendientes para el desarrollo de nuestro proyecto comunitario. Pregúntale a las niñas cómo van con sus responsabilidades, y ayúdales en lo que sea necesario. Recuérdales que faltan tres sesiones para que concluyamos nuestro ciclo, y que al final deberemos presentar juntas este proyecto a nuestra comunidad. Revisa tu cronograma, tu plan de trabajo, y trata de ir cerrando la preparación del proyecto. Pronto será el momento de presentarlo a la comunidad. Despide la sesión con alegría y deséales a las niñas que tengan buena semana.

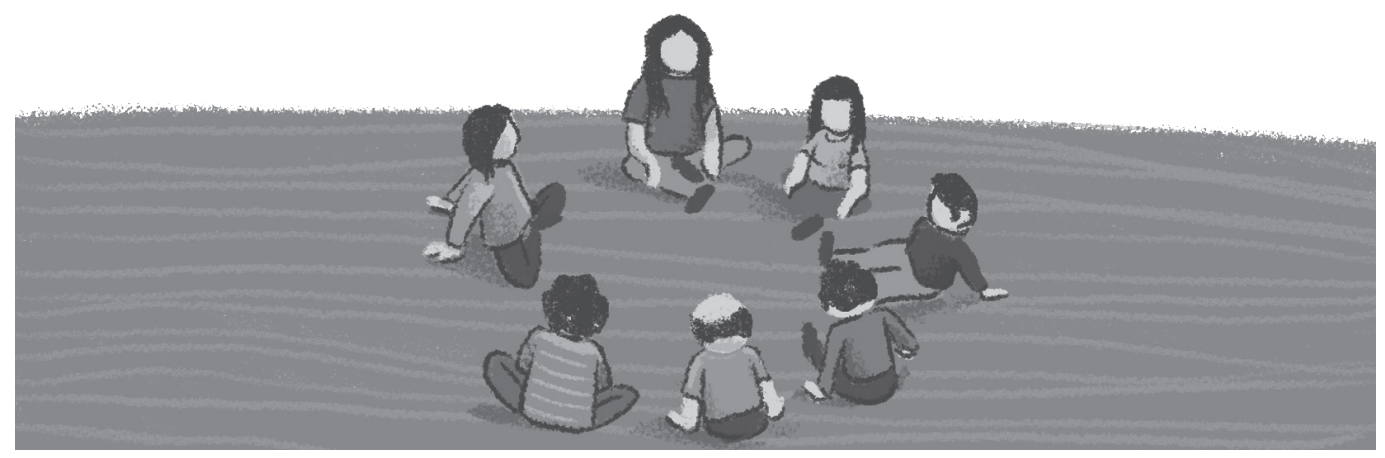

$$
\text { Guia para mentoras de Abriendo } O_{\text {portunidades }}{ }^{(8}
$$




\section{Sesión 16}

\section{La lucha también es mujer}

\section{Hagamos memoria}

Dale la bienvenida a todas las participantes. Invítalas a recordar los contenidos que compartieron la semana pasada. ¿̇Recuerdan a Mamá Maquín? ¿̇Qué podemos decir de ella? De ser posible, completa los datos de la sesión anterior con una investigación previa a la sesión, ya sea en internet o con las personas mayores de tu comunidad.

\section{Nuestras grandes preguntas}

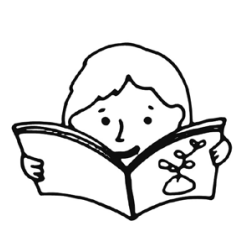

En esta sesión nos haremos una pregunta que todos los pueblos se han hecho, en cualquier momento y en cualquier lugar: $\dot{2}$ Es posible sanar las heridas de nuestro pasado?

Pregúntales su opinión a las niñas.

Déjales claro que siempre es posible retomar el hilo de nuestra historia y construir juntas un porvenir mejor. Sin embargo, para hacerlo es necesario reconocer el pasado que nos tiene hoy aquí y hablarlo con franqueza. Sólo la verdad y la justicia nos podrán enseñar las lecciones útiles de nuestra historia.

\section{Las palabras que nos nombran}

Hoy conoceremos un poema de Rosa Chávez. Ella nació en Chimaltenango en 1980, y ha escrito estas palabras que hablan de nuestra fuerza colectiva e individual, a pesar de todos los golpes que la historia nos ha dado:

Nos quitan la cabeza y el corazón

sigue latiendo

nos arrancan el pellejo y el corazón

sigue latiendo

nos parten a la mitad y el corazón

sigue latiendo

beben nuestra sangre y el corazón

sigue latiendo

estamos criados para latir sin descanso. 
Reflexionen juntas:

- ¿Recuerdan el significado de la palabra "resistir"?

- ¿Qué nos trata de decir este poema?

- ¿2Podemos sentir la fuerza de nuestros corazones?

\section{Los relatos de Esperanza}

Los Círculos de la Memoria le han servido mucho a Esperanza. Escuchemos con atención lo que le pasó a nuestra amiga:

\section{La tierra también es mujer}

Esperanza quedó muy entusiasmada con los Círculos de la Memoria que

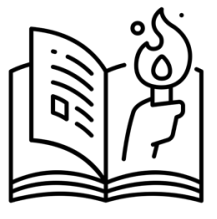
estaban organizando en la cooperativa de su comunidad, y las siguientes reuniones fueron muy importantes para ella. Parecía claro que todos necesitaban un espacio para poner su voz frente a las otras personas, para poder contar su dolor y su miedo, pero también la forma en que habían resistido a ese dolor y a ese miedo, la forma en que habían seguido vivos, con ilusiones y con esperanzas.

En esas reuniones, entre todos fueron tejiendo la memoria de su comunidad, entendiendo que eran parte de algo mayor, y que sobre todo se habían tenido que enfrentar siempre a las invasiones de sus territorios, porque incluso la guerra que habían atravesado tenía que ver con intereses de personas que querían utilizar la tierra, el agua y los recursos naturales para su beneficio.

Así conoció Esperanza lo relacionado a la Masacre de Panzós, que hizo que su abuelito Lix viniera a la que ahora es su comunidad, con sus dos hijos todavía pequeños. Su esposa - doña Cándida, la abuelita de Esperanza- era de Panzós, y después de casarse don Lix se había ido a vivir ahí con ella. Pero cuando la comunidad empezó a exigir que les devolvieran sus tierras, las cuales habían sido tomadas de forma deshonesta por personas que se convirtieron en terratenientes gracias al robo, empezaron los problemas y las amenazas.

Ese era el nudo de la historia de sus abuelos. Esperanza conoció más de cerca por qué a veces su abuelo se ponía triste, por qué el nombre de su abuela era recordado con dolor y llanto. A ella la habían matado en una masacre que el ejército hizo precisamente en Panzós. Mataron a casi cincuenta personas para dejarles claro que la tierra era de ellos, de los poderosos. Cincuenta vidas arrancadas, cincuenta historias de sangre. Y entre esas cincuenta estaba su abuelita Cándida.

Don Lix le dijo que lo perdonara por no hablar de eso, y le explicó que su corazón a veces sentía que no aguantaba con tanta tristeza junta.

-Pero no tengás pena, mija; yo a tu abuelita la veo en vos, la vi en Dolores, tu mamá, y sobre todo en tus preguntas, en tu forma de buscar. Ha sido linda la vida a pesar de todo, y es linda porque seguimos luchando, porque tenemos sueños, porque queremos la felicidad, porque la buscamos.

$$
\text { Guia para mentoras de Abriendo Oportunidades }{ }^{(3)}
$$


Así le dijo su abuelo, y Esperanza recordará siempre esa plática con él.

En sus reuniones de AO, Quetzalí les había empezado a hablar a las niñas de esos mismos hechos: de las masacres, de Mamá Maquín, de Panzós. Y entonces llegó el día en que la mentora y su amiga Débora -que también era mentora de un grupo cercano- les contaron una parte muy fuerte y muy triste que había dejado la guerra.

Esa tarde, Quetzalí les pidió que hicieran un círculo. Ella se puso al centro y muy seria les dijo que hablarían de su cuerpo, de su cuerpo de mujeres, de lo maravilloso que es ese cuerpo por el diálogo que tiene con la tierra, con la luna, con la naturaleza.

Sus palabras fueron claras:

-Este cuerpo es el primer territorio que habitamos y el primer territorio que tenemos que defender -les dijo.

Las niñas la miraban con atención.

Entonces, entre Débora y Quetzalí les contaron que además de las matanzas, en las guerras había existido muchísima violencia sexual contra las mujeres. Que los cuerpos de hombres y mujeres fueron violentados, pero que los de las mujeres-además- habían sido abusados, que había existido muchas violaciones sexuales.

-Y esto se los contamos para que sepan que las mujeres, a lo largo de la historia, han sufrido este tipo de violencia. $Y$ es por eso que estamos reunidas, aprendiendo y hablando, porque no está bien que eso se guarde en el silencio, porque si no se habla, es como si fuera algo normal, y no lo es: es una violencia espantosa la que se sufre, afecta la mente, el alma, y hace que la memoria duela -les dijo Débora.

- ¿̇Por qué han hecho eso con las mujeres? -se escuchó la voz de Mayra en el salón, compañera de Esperanza, en el salón.

-La historia ha sido dura para las mujeres en todo el mundo. En algún momento, la mujer-como la tierra-se empezó a ver como una propiedad, y si no se puede tener esa propiedad por las buenas, hay gente que busca tenerla por las malas. En el caso de la tierra, se hacen invasiones, se mata a la gente que vive ahí, se talan árboles, se mueven los ríos. En el caso de las mujeres, se las toma por la fuerza, se les obliga a quedarse en silencio, a hacer lo que no quieren...

$-\dot{i} \mathrm{O}$ sea que lo que siente la tierra con los palmeros o con las minas, es lo que han sentido las mujeres que han sido violadas? -se escuchó la voz de otra niña.

-Sí, es lo mismo: la tierra y la mujer tienen la misma energía. La tierra y la mujer son cuerpos de distintos tamaños, les crece la vida, la dan como sustento. Del mismo modo que la tierra es violentada con monocultivos, que es reventada por las minas, así muchas mujeres fueron violentadas por hombres durante la guerra.

Las niñas sintieron miedo, pero Quetzalí las fue calmando cuando les explicó que esto no era algo lindo de aprender, pero sí que era necesario, por el respeto a la memoria de las abuelas, y porque así podrían aprender a cuidarse entre sí y a crecer con sus amigos hombres de una manera más sana y normal.

Débora y Quetzalí les contaron que esos hechos que marcaron a tantas mujeres habían llegado a la justicia, que habían habido juicios; que las matanzas, las violaciones y las muertes injustas habían sido demasiadas, pero que la gente nunca había dejado de luchar, y algunos habían logrado llegar a juicios en la capital. De hecho, un grupo de mujeres que ahora eran abuelas habían llevado el caso de los abusos que habían sufrido, 
y habían logrado condenar a los culpables.

Siguieron platicando durante unos minutos, y después de hablar taparon las ventanas del salón para que no entrara luz. En una computadora que Débora llevaba, vieron una película chiquita, en donde salían las abuelas de Sepur Zarco contando su historia. Esas mujeres -ahora viejitas- habían logrado que se reconociera el daño que les habían hecho, y eran un símbolo de dignidad y de lo que no debían permitir que pasara de nuevo.

A pesar de que lo que vieron en la pequeña película era duro y triste, las niñas se quedaron felices de ver cómo la justicia le devolvió la sonrisa a las abuelas, cómo su memoria es ahora un símbolo, cómo su dolor se hizo chiquito a la par de la valentía que tuvieron para buscar y encontrar justicia.

"El cuerpo es mi primer territorio, el primero que defiendo. La tierra es el cuerpo inmenso en el que vivimos. Que no violen la tierra, que no invadan mi cuerpo, que no violen la tierra, que no invadan mi cuerpo..." Repitiendo estas palabras en su mente, Esperanza caminó a su casa, sintiéndose feliz -a pesar de todo- por ser hermana de la tierra.

\section{Hagamos algo juntas}

Hoy haremos un cine-foro, igualito al que Esperanza y sus amigas

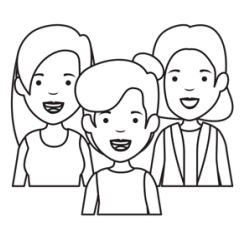
tuvieron en el relato que acabamos de escuchar. Trata de conseguir lo necesario para que todas puedan ver cómodamente este pequeño video sobre las Abuelas de Sepur Zarco. De ser posible, proyecta el video sobre un muro grande, para que lo vean con claridad. Si resulta complicado, comparte con las niñas en enlace y véanlo en parejas o pequeños grupos desde la pantalla de un celular.

La película se llama "La Abuelita Valiente", del director Ameno Córdova. Veámoslo con atención:

https://www.youtube.com/watch?v=7rlgU-65jłw

Al terminar de ver la película, reflexionen juntas sobre su experiencia a partir de las siguientes preguntas:

- ¿QQué les pareció?

- ¿̇Habían oído antes sobre Sepur Zarco?

- ¿Conocían la historia de las abuelas de Sepur Zarco?

- ¿Cómo se relaciona esta historia con todo lo que hemos aprendido en estas sesiones?

- ¿̇Conocemos algún caso parecido cerca de nuestra comunidad? 


\section{Oportunidades en casa}

Antes de despedir esta sesión, recuérdale a las niñas todo lo relacionado con el cierre de su proyecto comunitario. Pídeles que durante la semana, informen a sus familiares de dicho proyecto, de los avances, de lo que quieren lograr juntas con sus compañeras. Es importante que los familiares de todas se interesen por el proyecto comunitario del grupo, así que deberán platicar con ellos durante la semana para contarles sus planes y pedirles la ayuda que sea necesaria. 


\section{Sesión 17}

\section{Aquí está el milagro}

Hemos llegado a nuestra penúltima sesión. ¿Cómo nos ha parecido todo este proceso? Como Esperanza, żhemos aprendido algo sobre la historia de nuestros territorios y nuestras comunidades? Platica con las niñas e invítalas a participar con libertad y confianza.

\section{Hagamos memoria}

Durante las tres últimas semanas, hemos hablado del Gran Problema, del enfrentamiento que durante más de 30 años se vivió en Guatemala. Antes de la sesión, investiga un poco sobre los Acuerdos de Paz, y explícales a las niñas el proceso mediante el cual terminó la guerra en 1996.

Luego, realiza las siguientes preguntas e impulsa la conversación entre todas:

- ¿QQué acontecimientos importantes para nuestra comunidad recordamos haber vivido?

- ¿Cuáles son las cosas buenas, las cosas agradables que nuestra comunidad nos ha puesto en la memoria?

- ¿̇Qué momentos difíciles recordamos haber vivido en la comunidad?

En estas últimas sesiones, hablaremos del presente. Así que utiliza tu propia memoria para guiar la conversación.

\section{Nuestras grandes preguntas}

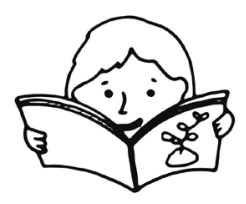

Se dice que en Guatemala la era democrática empezó en 1985, cuando entró en vigencia la actual Constitución Política de la República. ¿¿Qué quieren decir esos conceptos? Comparte con las niñas estas preguntas y traten de construir juntas una respuesta:

- ¿QQué significa la democracia?

- ¿Qué es la Constitución?

Recuerda que la democracia es un sistema político en que la soberanía reside en el pueblo, que la ejerce directamente o a través de representantes electos por medio del voto. En ella se reconoce la libertad y la igualdad de todos los ciudadanos ante la ley. Se basa en la participación popular para la toma de decisiones políticas.

$$
\text { Guia para mentoras de Abriendo Oportunidades }{ }^{(3)}
$$


Asimismo, la Constitución Política de la República es la ley suprema de Guatemala, en la cual se rige todo el Estado y sus demás leyes. Es importante porque recoge los derechos fundamentales de la población. Entró en vigencia en 1985. Es importante conocerla, porque en base a lo que dicen sus artículos podemos exigir que se cumplan nuestros derechos fundamentales.

Trata de vincular estas definiciones con la vida cotidiana desde la comunidad. ¿Qué significa la democracia, los derechos, las leyes, desde nuestro día a día?

\section{Los relatos de Esperanza}

A pesar de lo que estipulan las leyes vigentes del país, muchas características de nuestra vida cotidiana nos hacen sentir que las cosas no están bien. Por donde quiera que miremos, encontramos situaciones que nos afectan individual y colectivamente: la pobreza, la violencia, la falta de oportunidades, todo lo que dificulta nuestro desarrollo y nuestra relación sana con el entorno.

Acompañemos a Esperanza en este relato que tiene que ver con la actualidad de muchas personas en nuestro país:

\section{Aquí y ahora}

La gente que les había robado el río estaba muy enojada. Por lo menos una vez a la semana aparecían dos picops con gente armada. Intimidaban a la comunidad, pasaban enseñando sus armas, querían causar miedo para evitar que siguieran interrumpiendo el desarrollo de

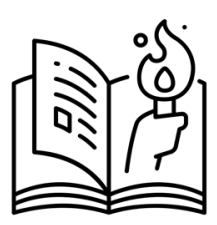
sus siembras, que eran de beneficio sólo para ellos. Porque para todos lo demás, el monocultivo era un sufrimiento. La primera en sufrir era la tierra, a la que le arrancaban sus bosques que durante muchísimo tiempo había hecho crecer; luego la llenaban de siembras que la dejaban seca, y después le cambiaban de lugar sus ríos para que esas nuevas plantaciones -inmensas, todas iguales- se acabaran el agua. $Y$ luego sufría la gente, porque la gente y la tierra no son dos cosas distintas, son una sola composición de la vida que necesita cuidarse entre sí.

También se había escuchado de una mina que se dedicaba a reventar la tierra, a escarbarla para sacar níquel, cobre, platino y otros nombres extraños.

-Como si lo más valioso que le nace a la tierra no fuera la vida que nos da -le decía don Lix a Esperanza cuando se oían cosas de las minas, porque además se iban árboles, animales, hasta los cerros se acababan por estar escarbándole sus entrañas a la tierra.

-Es que esas son cosas que no deberían ver la luz, son de la tierra, son sus secretos -decía enojado el abuelo.

Un día que venían de regreso de poner sus productos en el mercado de una comunidad 
cercana, la gente de la cooperativa se llevó un gran susto: la laguna hermosa que parecía un ojo grande que veía al cielo estaba amarilla, hecha casi lodo. Se estaba cerrando el ojo de agua.

Llorando, Doña Berta se acercó al poquito de agua que estaba como agonizando, y le dijo:

-i¿̨Qué te hicieron, agüita?! ¿Quién te enfermó? ¿QQuién te puso venenos y te fue matando?

Tristes y asustados regresaron todos a su aldea. Esperanza no podía creer cuánto daño le hacían a la vida, cuánto eran capaces de arrebatar. Le dijo a su abuelo que a veces le daban ganas de irse con sus papás, que no le gustaba estar en Guatemala, que todo estaba mal aquí. Su abuelo no le dijo gran cosa, porque ante todo quería que se calmara.

Esperanza sintió que de la esperanza sólo le quedaba el nombre. Ríos robados, lagunas muertas, mujeres abusadas, abuelas violentadas, guerras, invasiones, arrebatos... sentía cada una de esas palabras en su pecho y deseaba esconderse, irse lejos.

Un par de días después, su abuelo regresó de hablar con el fuego. Era un día Tzikin, y su abuelo decía que había que ir a buscar buenas noticias, que había que ir a hablar de fortuna y felicidad con el fuego. Al mismo tiempo que regresaba, llegó doña Irma, la vecina que tenía un hijo que trabajaba en la cabecera municipal, en un lugar donde recibían encomiendas del extranjero y remesas, dinero que mandaba gente que estaba trabajando en Estados Unidos.

Los papás de Esperanza mandaban dinero cada mes, pero ese día además de los billetes su mamá le había mandado una carta a Esperanza. Sin decir gran cosa, ella la recibió. Se fue a su huerto, encendió un foquito que iluminaba cerca de la pared, y con las manos temblorosas abrió la carta que estaba escrita con lapicero azul en unas hojas rayadas:

"Boston, Massachusetts, 21 de mayo de 2021.

Mijita:

Esperancita, disculpá que no te haya escrito antes una carta, pero estoy segura que mi papá te ha contado que siempre le preguntamos cómo estás, si te va bien en la escuela, qué tanto has crecido, si te acordás un poquito de nosotros, tus papás.

Te escribo porque siento que ya debés estar grande y quiero que a partir de ahora nos mandemos cartas. Y mejor así, escritas con la mano, aunque cueste que lleguen, porque así sé que esto que estoy tocando también lo van a tocar tus manitas, que cuando las toqué por última vez todavía eran muy chiquitas.

Mija, estar lejos es tan difícil para nosotros. Tenemos que trabajar mucho, tenemos que medio hablar en inglés con los jefes, tenemos que tramitar nuestros permisos para estar aquí trabajando y eso tarda años; eso sí, cuando todo se arregle nos vamos a ir a verte.

Te cuento que aquí vivimos en un edificio algo viejito, donde vive gente de otros países. Muchos hablan español, pero hay otros de lugares más lejanos. Cuando yo me levanto, miro para la ventana y pienso: "¿Será que para allá está Guatemala? ¿Será que si camino aquí recto llego con mi Esperanza?", y para qué te digo mentiras: me da una tristeza

$$
\text { Giva para mentoras de Abriendo Oportunidades }{ }^{\circledR}
$$


grande, pero sabés que todos los días pienso en el día que te vuelva a ver.

Nosotros nos venimos porque de verdad ya no se podía, ya no teníamos de dónde, y acá hemos encontrado trabajitos, y por lo menos nos alcanza para mandar lo necesario para tu vida y la de tu abuelito. Acá, como en todos lados, hay gente buena y gente que hace daño, hay mucha gente muy pobre, hay gente en la calle. Y uno que se imaginaba que esto era como el cielo... ide dónde!

Pero fijate que a veces pienso que aunque acá se supone que hay más oportunidad, allá en Guate hay cosas que todavía pueden nacer, que todavía están por verse. Aquí, en cambio, parece que la gente ya supiera cómo va a ser el final de la película y ya nada les interesa mucho. Pienso en lo que me ha contado mi papá de tu huerto, que dice que estás muy lista, que preguntás muchas cosas, que a veces te agarra la tristeza por las cosas malas que pasan o han pasado.

Mijita chula, no te angustiés, mirá que uno aquí lejos se da cuenta de lo lindo que es allá, un lugar lleno de gente buena, lleno de esperanza (por eso te quise poner así). Es cierto que la vida ha sido dura, mamita, pero los ratos de felicidad, pensar, imaginar, eso es lo más lindo de la vida. Te imagino cuidando tu huertito y siento que vas a poder hacer muchas cosas. Me contó tu abuelito que también estás yendo a un grupo, y que te han enseñado mucho. Qué bueno, mija. Mirá que allá hace falta gente que quiera hacer cosas por los otros, que conozca de nuestra historia, que la cuente...

Cuando te angustiés, sentí que el país en el que naciste todavía es chiquito, que hay que ayudarlo a crecer, que hay que curarle sus heridas. Acá lejos uno mira eso muy claro. Vieras las ganas que dan de estar allá. Y no sólo estar, dan ganas de estar luchando como lo han hecho ustedes, con el río, con la cooperativa, con los huertos... Pero que lo estés haciendo, Esperancita, es como que tu papá y yo lo estuviéramos haciendo con vos.

La próxima vez que te sintás angustiada, recordate que no estás sola, y que no hay lucha pequeña, toda lucha es grande, y que lo que estás haciendo ayuda a la tierra que querés, a la gente con la que vivís, a los arbolitos y los ríos que mirás.

Ya no sigo escribiendo porque van a creer que el sobre va lleno billetes y capaz se lo roban, sólo te quería decir que sos nuestra florecita en las montañas, nuestra risa, nuestras ganas de volver.

Te quiere mucho, Dolores, tu mamá.

Esperanza dobló la carta, se la llevó al pecho y sintió que le había nacido algo nuevo adentro. Aunque su mamá estaba lejos, no sentía las ganas de irse corriendo: sentía ganas de cuidar su lugar, su tierra, su vida, para que cuando sus papás algún día regresaran vieran que éste era un mejor lugar que el que dejaron.

\section{Reflexionen juntas:}

- ¿Qué piensan de lo que le sucedió hoy a nuestra amiga Esperanza?

- íla carta que le envió su mamá dice algo que nosotras podamos aplicar a nuestra propia vida? 
- ¿Creen que el Gran Problema tiene algo que ver con la falta de justicia en la actualidad?

- ¿Qué impacto tiene nuestra historia reciente en la cantidad de personas que migran a Estados Unidos?

- ¿̇Conocen casos cercanos, de familiares o amigos, que han tenido que migrar fuera del país?

\section{Las palabras que nos nombran}

Hoy nos acompañan las palabras de un poeta guatemalteco llamado Maurice Echeverría. Este poema fue escrito hace unos cinco años, y habla de nuestro presente, de lo que él y muchas personas más han sentido al trabajar todos los días para construir una realidad mejor. Escuchémoslo con atención:

\section{Aquí está el milagro \\ (fragmento) \\ Maurice Echeverría}

Aquí es.

Aquí está el milagro.

Verán: dentro

de tanta sangre negra

hay cosas inexplicables de la vida.

Hierbas

humildes

que nacen

en la banqueta

donde quedó el último muerto.

$\dot{2}$ No es de veras

extraordinario

cómo seguimos

germinando

y pariendo

y regalando semillas

resucitadas

a los ángeles?

¿̇lrme, pues, a dónde? 
Aquí está el auténtico trabajo.

Aquí es donde hay que trabajar.

Aquí son las venas rotas

sintiendo, desesperadas, la vida.

Reflexionen juntas: ¿̇ué nos hace sentir el poema? ¿Alguna vez hemos pensado algo parecido? ¿Vale la pena luchar por el lugar en el que vivimos, por la gente que nos rodea?

\section{Hagamos algo juntas}

En esta actividad trataremos de pensar juntas en nuestra comunidad.

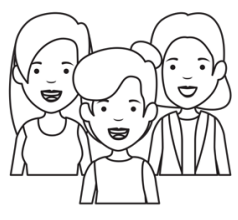
Pídele a las niñas que se integren en parejas, y que platiquen sobre las siguientes preguntas:

- ¿QQué oportunidades nos brinda nuestra comunidad?

- ¿Qué necesita nuestra comunidad de nosotras?

- ¿Cómo podemos trabajar para que nuestra comunidad sea mejor?

Estando en parejas, traten de responder esas preguntas. Para hacerlo, pueden realizar dibujos o hacer un listado de las ideas que compartan. Luego de un tiempo prudencial, reúnanse nuevamente y pongan en común lo que pensaron.

\section{Oportunidades en casa}

Estamos a punto de concluir nuestro ciclo de aprendizaje. Y para esta

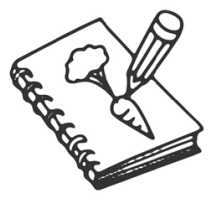
semana les dejarás una tarea que será muy importante en la próxima sesión: pídele a las niñas que averigüen sobre los movimientos - redes de mujeres que existen en la comunidad. Diles que pregunten a las autoridades comunitarias, que dialoguen con sus familiares y con las personas mayores de la comunidad, para responder las siguientes preguntas:

- $\dot{2}$ Existen redes de mujeres en la comunidad?

- ¿A qué se dedican?

- ¿̇ómo es la vida de las mujeres en nuestra comunidad?

Tomen nota, hagan dibujos y recuerden las respuestas, pues será lo primero que platicaremos la próxima semana, en nuestra última sesión. 


\section{Ruta hacia un proyecto comunitario}

Antes de despedir esta sesión, pídele a las niñas que organicen el cierre de su proyecto comunitario. A estas alturas, las actividades que le correspondían a cada una deben haberse cumplido. Por eso, ahora nos corresponde pensar qué actividades y qué recursos necesitaremos para presentar a nuestra comunidad el proyecto que hemos estado trabajando durante todas estas semanas.

Platiquen juntas al respecto, y organicen las tareas que sean necesarias para la presentación. Recuerda que deberás invitar a los miembros de la comunidad y pensar en una dinámica atractiva para exponerles lo que han preparado juntas durante estas semanas.

La creatividad y el trabajo en equipo serán tus mejores herramientas. Motiva a las niñas a utilizarlas para cerrar de la mejor manera el proyecto comunitario de tu grupo de Abriendo Oportunidades ${ }^{\circledR}$.

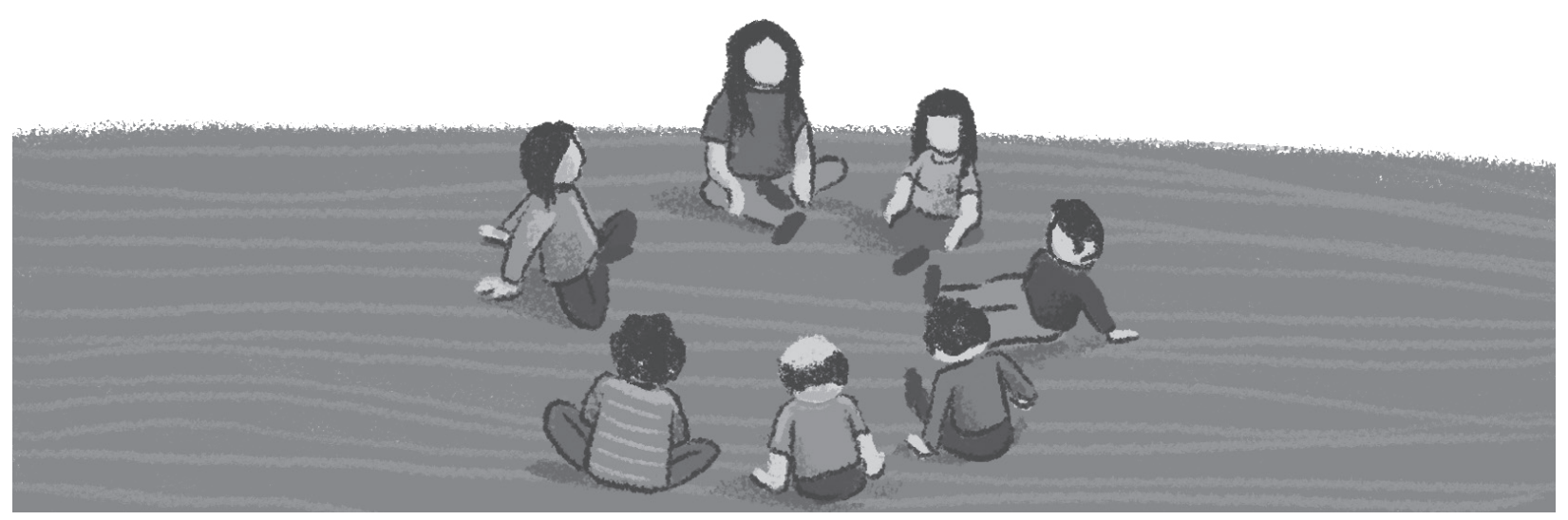




\section{Sesión 18}

\section{Nosotras también somos historia}

Hoy es un gran día para todas las que hemos formado parte de este grupo de Abriendo Oportunidades ${ }^{\circledR}$. Luego de 18 semanas, hemos podido recorrer la historia de nuestros territorios y nuestras comunidades, aprendiendo juntas con Esperanza. Cuando las niñas empiecen a llegar al lugar de reunión, recíbelas con alegría y platiquen sobre todo este proceso que hemos transitado.

\section{Hagamos memoria}

¿Verdad que las mujeres hemos sido siempre una fuerza fundamental dentro de nuestras comunidades? Pídele a las niñas que nos cuenten su experiencia de trabajo en casa durante la semana, investigando sobre las redes y movimientos de mujeres que han existido en nuestra comunidad. ¿Qué tal les fue averiguando al respecto?

Las preguntas que planteaste la semana pasada, y que ahora deben responder juntas, son las siguientes:

- ¿Existen redes de mujeres en la comunidad?

- ¿̇A qué se dedican?

- ¿Cómo es la vida de las mujeres en nuestra comunidad?

Las niñas podrán compartir las notas, los dibujos, los hallazgos que hayan tenido durante su investigación; y tú podrás compartir con ellas la información que hayas reunido. Es importante que todas reconozcamos y valoremos el trabajo que a lo largo del tiempo y en la actualidad realizan nuestras compañeras en el espacio más cercano.

\section{Las palabras que nos nombran}

Durante muchas sesiones, hemos conocido una pequeña muestra de los poemas y los relatos de distintos escritores guatemaltecos. En esta ocasión, nos acercaremos a un poema fundamental de nuestra poesía. Se llama Madre, nosotros también somos historia, y lo escribió Francisco Morales Santos (La Antigua Guatemala, 1940). En el poema, Francisco recuerda a su mamá, y le dedica estas palabras:

¡Cuán espléndida has sido todo el tiempo amparándome en el diáfano cielo de tus ojos!

Los días ordinarios los has hecho mejores 
hasta parecer de cumpleaños.

Siempre has sido igualita a ti misma;

tu riqueza provino de la tierra al igual que tu hermosura.

Lástima grande que no pueda grabar en el poema tus palabras, pero tengo el placer ilimitado de guardar su eco,

la suerte de apoyar mi corazón sobre ellas.

He cantado tu presencia entre plática y plática

mientras unas estrellas aparecen y otras ceden el sitio

a tu memoria. Colocando los pies sobre la tierra

he tomado tus grandes sentimientos para arrostrar el tiempo.

Quiérase o no, tus actos han sido la argamasa con que se edifica

este país carajo; país hecho de actos sencillos y humanos simples

que, al cabo, es lo que cuenta,

porque nosotros, madre, también somos historia.

Pregúntales: ¿QQué piensan de estas últimas palabras del poema? ¿̇Nosotras también nos sentimos parte de la historia?

\section{Los relatos de Esperanza}

Algo importante pasará hoy en la vida de Esperanza y sus de sus compañeras. ¿̇erá que algo parecido nos puede pasar a nosotras? Escuchemos con atención:

\section{Alzar el vuelo}

Estaba caminando descalza. Sentía la tierra, la grama, el lodo, las ramas. Aunque no iba angustiada, avanzaba muy rápido. Tenía que encontrarse

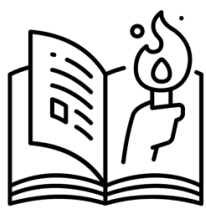
con alguien en la orilla del río. Esperanza vio la luz del sol y las sombras con forma de ramas y hojas sobre su piel. Se quedó viendo un rato el detalle de la vida que se marcaba en la superficie de sus brazos. Cuando levantó la vista, ya estaba en la orilla del río; sin caminar había llegado. Una mujer mayor la esperaba sentada sobre una piedra. El canto de los pájaros se escuchaba fuerte, y entre el rumor del río la voz de la mujer empezó a hablarle:

-Ch'ona'. Chan ru wankat.

En ese momento, Esperanza supo que la señora era su abuela Cándida. Quiso hablarle, pero no podía. Sentía que hablaba y no le salían palabras.

-Lo que me querrás decir, decíselo al aire. Si me querés abrazar, cuidá la tierra. Si me querés ver, mirate en el reflejo del río. Si me querés preguntar, preguntale al fuego.

Esperanza le quería ver la cara, pero ella estaba sentada de frente al río y no se volteaba. La abuela Cándida siguió hablando:

$$
\text { Evia para mentoras de Abriendo } O_{\text {portunidades }}{ }^{(2}
$$


-Vine a decirte que te vamos a necesitar, también a tus amigas y a toda la gente de la aldea. La vida necesita que la cuiden. Yo ya no estoy en la vida, pero mientras alguien me recuerde, tengo la obligación de guiar a esa persona hacia los días buenos. Vamos a necesitarte porque con tus preguntas has abierto caminos, porque con tu memoria vas a alimentar a los otros, porque con tu fuerza pueden pasar cosas buenas...

Su abuela seguía hablando, pero Esperanza casi no podía entenderle. Su voz se hizo rumor de río, su cuerpo se hizo paisaje. Esperanza se limpió los ojos para tratar de verla, pero cuando los abrió estaba en su cama. Un día nuevo empezaba.

Los miembros de la Cooperativa había llegado a un acuerdo: como las siembras de la palma africana estaban rodeándolos, con el dinero que iban reuniendo comprarían pequeños pedazos de tierra para recuperar la vida que tenían antes, para volver a sembrar árboles y hacer huertos más grandes. Aunque no había sido nada fácil, poco a poco lograron comprar un primer trozo de tierra.

El día que les dieron los papeles de la propiedad, don Lix hizo un fuego grande para agradecer pero también para pedir que la tierra sanara, que volviera a nacerle todo tipo de vida, que se le quitara la enfermedad de la palma. Casi toda la comunidad fue a la ceremonia, y aunque no dejaron de tenerle miedo a los hombres de la palmera que los intimidaban con sus armas, estaban muy felices.

Después de hablar con el fuego, todos fueron al salón comunal para celebrar con comida de sus huertos; pusieron pino, bailaron. En medio de la fiesta, Esperanza seguía escuchando la voz de su abuela, a la que nunca conoció, pero que le dio ese mensaje tan claro cuando la soñó pocas noches antes. Le contó a sus amigas el sueño:

-Yo siempre he sentido que tengo que hacer algo -dijo Gloria-, porque ya viste todo lo que nos han contado los viejitos en el Círculo de la Memoria. Yo sí creo que luchar está en nuestra sangre, y es que si no lo hacemos la gente va a seguir naciendo aquí en la comunidad ya con el montón de trabajo, el poco dinero y la falta de todo.

Esperanza la escuchó y sintió que tal vez ya se estaban haciendo grandes, que todavía eran niñas pero que estaban cambiando.

Esa tarde hablaron de lo que querían ser en el futuro. Una iba a ser maestra, otra arqueóloga, otra doctora, otra pintora... Esperanza seguía pensando que quería ser arqueóloga, porque todo lo que le había dicho el fuego aquella tarde sobre su pasado y las ciudades antiguas le daba unas ganas inmensas de buscar el camino de regreso a esos días, en los que la gente construyó montañas, en los que se hablaba con las estrellas.

Quetzalí las pasó saludando, y les dijo que tenía un plan para hacer en sus próximas reuniones de $\mathrm{AO}$ : iban a ir a una excursión, y les pidió que preparan su mente, su cuerpo y su espíritu para hacerlo, porque iban a subir una montaña.

Los días pasaron, y cuando llegó el momento de la excursión se reunieron todas bajo el árbol grande que está frente al salón. Esperanza llegó con su abuelito, que llevaba una carga de candelas, copal, pom, azúcar y flores. Ellas también llevaban sus ofrendas. Quetzalí las reunió y les dijo: 
-Hoy vamos a imaginar que ese cerro es la vida. Ahorita que empezamos a caminar es como si acabáramos de nacer, cuando lleguemos a la cima será la mitad de la vida, y al bajar será el final.

Aún estaba oscuro cuando empezaron a andar. Se metieron a una vereda que está atrás de la escuela. Iban una tras otra, y Quetzalí les iba diciendo que recordaran su vida, que pensaran en su recuerdo más lejano, o incluso en lo que sus papás les habían contado de lo que ellas ya no recordaban. Esperanza veía sus pies sobre la vereda y recordaba a lo lejos a su mamá dándole comida, a su papá llamándola desde afuera, a su abuelito más joven, y el río que se veía más grande, tal vez como del tamaño del mar.

-Piensen -les decía Quetzalí- en los momentos más importantes de su vida, no sólo los alegres, también los tristes.

Y Esperanza se recordó llorando mucho la noche que se fueron sus papás con una mochila en la espalda. También se acordó de su primer día de escuela, del día que pudo escribir su nombre, de su abuelito trabajando y ella haciendo su tarea, de las flores que nacían en mayo, de los partidos de fútbol con sus amigas, del día que la tierra le contó la historia de la gente que vino de muy lejos, de las canciones que le gustaban, del dolor de ver a su río seco, de la vez que en Cobán hicieron su altar cívico, de la vez que habló con el fuego...

-Ahora piensen cómo eso que han vivido les dice qué deben hacer en el futuro -les decía la mentora, mientras avanzaban-. ¿QQué les dice su camino? ¿Para dónde tienen qué andar? ¿̇Cómo se imaginan su vida en el futuro, pero también cómo imaginan la vida de la gente que quieren, de la comunidad, del país, del mundo?

A través de los árboles, Esperanza veía el color del cielo que ya había cambiado: ya era azul y no negro, porque la luz del día ya estaba a punto de llenarlo todo.

Despuecito llegaron a una cima. Ahí había un espacio sin árboles. Todas se asomaron a ver su aldea. Ahí estaba: chiquitita, parecía como dormida, con un color parecido celeste que la cubría, con los humitos saliendo de las casas.

-Piensen -les dijo Quetzalí- en el lugar en el que nacieron, ese que ven ahí abajo; preguntenle a su corazón qué sienten por ese lugar.

Y Esperanza sintió que quería abrazar a su aldea, a su río, a cada persona que estaba ahí abajo. Se sintió como si ella fuera un pedacito de esa aldea.

Su abuelo había permanecido callado, escuchando las palabras de la mentora, pensando él también lo que Quetzalí le pedía a las niñas. Mientras tanto, había puesto las candelas, el azúcar, los copales, las flores. Cuando todo estuvo listo, Quetzalí les dijo que hicieran un círculo y que con lo último que pensaron y sintieron saludaran el día y vieran la llegada del fuego.

Era un día Kawok, un día de reunión y de comunidad. Saludaron a la existencia toda desde ahí, saludaron al aire, al cielo. A la tierra y sus raíces, a todas las criaturas, a todas las plantas, a las estrellas y los lugares que no alcanzan a ver con la vista, a los vivos y a los muertos, a los que no han nacido, a la gente que no conocen.

El fuego creció, creció mucho. Les mostró con sus formas la vida que debían defender, los rostros de la gente que había estado antes que ellas, y que habían cuidado sus tierras. El fuego -con su voz de llama- les dijo a las niñas que la vida que venía iba a ser buena si ellas se cuidaban, si aprendían, si escuchaban las voces de otros tiempos y las palabras

$$
\text { Guia para mentoras de Abriendo Oportunidades }{ }^{(3)}
$$


dormidas de los que no hablan pero nos cuidan, como los cerros, como los mares, como los animales.

Todas estaban muy atentas, y así pasaron un largo tiempo, cada una con sus preguntas, cada una con sus miedos, con sus esperanzas. Don Lix, que había contado cada día, cada energía, iba dejando que el fuego se fuera durmiendo.

Para ese momento, ya era una mañana soleada y brillante.

-Vean de nuevo para allá -les dijo Quetzalí-. Y véanse ustedes: sus manos, sus pies, tóquense el rostro, imagínense grandes.

Las niñas estaban conmovidas. Todas habían escuchado al fuego, todas había hecho memoria de sus años más lejanos, todas veían su pequeña aldea y el movimiento de la gente que la habita. Esperanza lo sabía: todo estaba conectado, el pasado con el futuro y con ese momento exacto. El fuego, las estrellas, el agua. La tierra, su abuela, las flores. Su huerto, sus sueños, sus tristezas.

$Y$ ahí, desde ese cerro, viendo otros cerros, imaginando la vida de otras aldeas, de otros pueblos y de otras gentes, Esperanza, tomada de la mano de sus amigas y de Quetzalí -mientras su abuelo seguía contando el tiempo- se vio alzando el vuelo, llegando a otras cimas, curando la tierra herida, liberando las aguas secuestradas, diciéndole sus nombres a los muertos escondidos, habitando ciudades que no estaban llenas de edificios sino de montañas, cuidando la vida que nacía...

\section{Nuestras grandes preguntas}

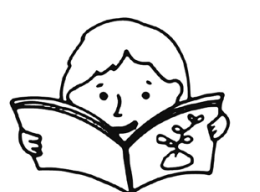

Todo proceso de aprendizaje nos deja muchas preguntas en la cabeza. Eso es bueno, eso hace que siempre necesitemos buscar más respuestas, más pláticas, más ideas que nos ayuden a entender lo que nos rodea.

Comparte esa reflexión con las niñas, y rétalas con las siguientes preguntas:

- ¿Qué nos queda de todo este recorrido por la historia de nuestros territorios y nuestras comunidades?

- Todo el conocimiento que hemos adquirido, żnos servirá para enfrentar el futuro?

Todos los relatos sobre lo que ha conocido Esperanza y lo que le ha pasado a ella, a su mentora, a su abuelito y a su comunidad, nos enseñan que hemos atravesado dolores y penas, pero hemos salido de ellas siendo más fuertes. Además, no estamos solas: hombres y mujeres de todos los tiempos nos acompañan, nuestras luchas de hoy expresan la misma fuerza que ellos expresaron antes y que otras personas expresarán después, cuando nosotras ya no estemos. ¿QQué nos hace sentir sabernos parte esta comunidad que atraviesa el tiempo y nos hace más fuertes? 


\section{Hagamos algo juntas}

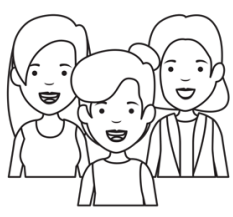

Estamos a punto de cerrar nuestro ciclo, y queremos que este cierre sea una celebración. ¿QQué celebraremos? La oportunidad que tuvimos de aprender juntas, de conocernos, de hacernos amigas y de compartir durante todo este tiempo. Celebraremos también las ideas y las preguntas que todas estas sesiones han dejado en nosotras. Celebraremos que somos una comunidad más grande, más unida y más fuerte.

Para esta última actividad colectiva, dirígete con las niñas a un lugar abierto, cómodo, seguro, donde puedan estar rodeadas de naturaleza y tranquilidad. De ser posible, suban a un cerro cercano o vayan a un parque rodeado de árboles.

Cuando estén ahí, reúnanse formando un círculo y pídele a todas que cierren un momento sus ojos. Que respiren hondo. Que sientan los ruidos que las rodean, que sientan el aire, que pongan en blanco su mente. Respira con ellas, relájate con ellas y diles palabras que las hagan sentir bien, que les trasladen lo que tú piensas de toda esta experiencia que están a punto de cerrar.

Luego de unos minutos, pídeles que abran los ojos y siéntense. De ser posible, sería magnífico que puedan compartir una pequeña refacción, algo sencillo y que no se complique mucho. En tu celular, o en alguna pequeña bocina, podrás reproducir estas y otras canciones, para que entre todas puedan escuchar sus letras, sentir los ritmos y bailar juntas para cerrar el grupo con una celebración.

Te recomendamos estas canciones, pero tú puedes agregar las que consideres pertinentes:

"Ojalá que llueva café en el campo", de Juan Luis Guerra

(República Dominicana).

https://www.youtube.com/watch? $v=8 b M D+A A D M 48$

"Semilla nativa", de Aterciopelados (Colombia).

https://www.youtube.com/watch? $v=y / r s P w d 3 h E I$

"El castigador", de Rita Indiana (República Dominicana).

https://www.youtube.com/watch?v=iD76WvNz9U8

"Las flores", de Café Tacuba (México).

https://www.youtube.com/watch?v=zJvMwTgWcP0

"La tierra del olvido", de Carlos Vives (Colombia). https://www.youtube.com/watch?v=-QkmEVNA-fo 
"El aguante", de Calle 13 (Puerto Rico).

https://www.youtube.com/watch?v=LUk73pUe9i4

"Alma mestiza", de Rebeca Lane (Guatemala).

https://www.youtube.com/watch?v=P8YOBB7kh2c

"Hasta la raíz", de Natalia Lafourcade (México, cantada por artistas de todo el continente).

https://www.youtube.com/watch?v=cUaKBGnn2DQ

Durante la convivencia, durante la fiesta y el baile, toma fotos con tu celular. Serán recuerdos que después podrás compartir con todas las participantes. De ser posible, tómense una foto grupal que sirva como un marcador de la memoria, que les recordará todo lo que han vivido y aprendido durante estas semanas.

\section{Presentemos nuestro proyecto comunitario}

A pesar de que hoy es nuestra última sesión, nuestro aprendizaje y nuestro compromiso con la comunidad de la que formamos parte no termina aquí. La última tarea pendiente es poner al servicio de la comunidad el proyecto que hemos venido trabajando durante todo este tiempo. Por eso, motiva a las niñas en esta última etapa para que la presentación de su proyecto sea un éxito. Demuestren juntas lo importante que es para la comunidad que sus niñas se reúnan para aprender y formar lazos más fuertes.

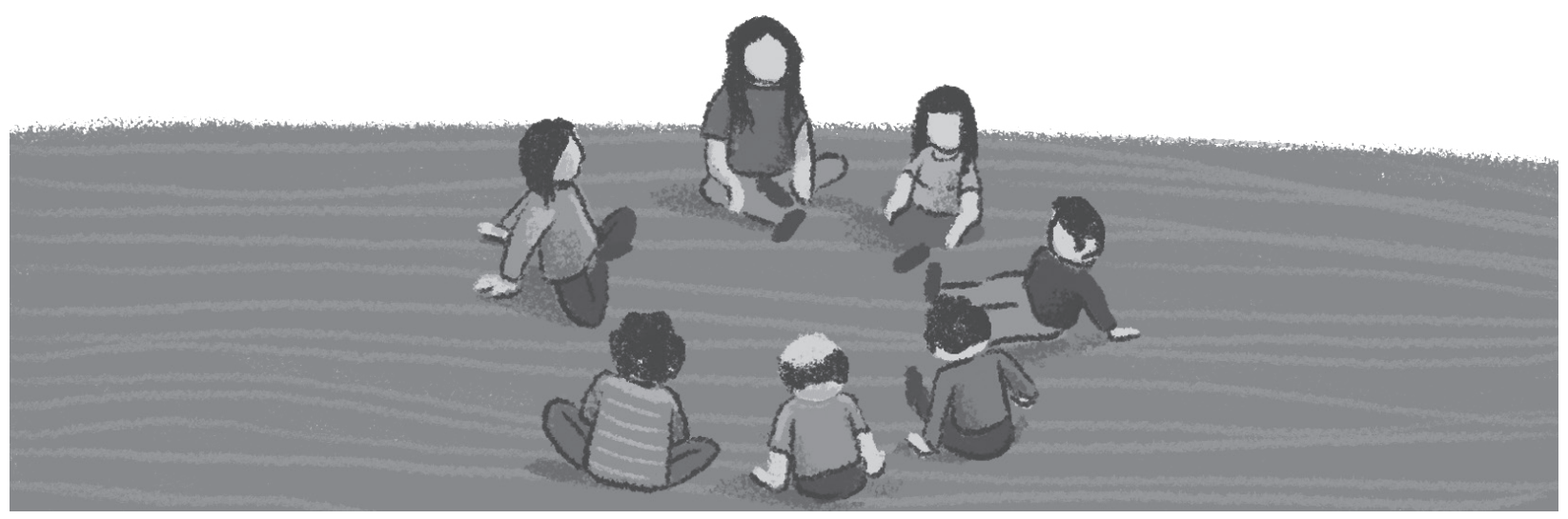




\section{Algunas palabras}

\section{que nos será útil aprender}

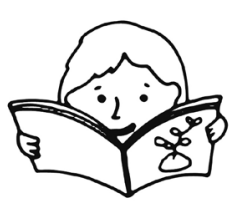

Dentro del orden colonial español en territorio americano, una capitanía es un territorio de segunda categoría en relación un virreinato. Está dirigida por un capitán general, y nuestro territoro fue parte de la Capitanía General de Guatemala, conformada por el sur de méxico y los actuales países de Centroamérica.

Los procesos de invasión no son solamente una batalla: son un largo proceso de lucha. Quienes son invadidos resisten; sin embargo, el hecho de ganar batallas y de imponer una forma nueva de ver el mundo significa que los territorios están conquistados, que ahora son diferentes, y que deben ser como el invasor quiere que sean. Es importante que tengas claro que una conquista no significa que no haya resistencias.

La cultura está conformada por todos esos pensamientos, conocimentos y formas que un pueblo ha creado a lo largo de su historia, tomando los elementos de su contexto, de su espacio y mezclándolos con otros conocimientos. No hay una cultura definida e inalterable, porque la cultura está viva, y la forma en que hablamos, en que contamos, lo que comemos, lo que aprendemos, está estrechamente ligado a la cultura, que es la que nos cuenta cómo vemos el mundo dependiendo del pueblo, la colectividad, el país y el continente en que hayamos nacido.

La democracia es un sistema político en que la soberanía reside en el pueblo, que la ejerce directamente o a través de representantes electos por medio del voto. En ella se reconoce la libertad y la igualdad de todos los ciudadanos ante la ley. Se basa en la participación popular para la toma de decisiones políticas.

Cuando algo que se poesee o es parte de los bienes coelctivos de una comunidad es arrebatado por la violencia, se denomina despojo. Regularmente en una batalla, en una invasión, la tierrra y los bienes culturales son arrebatodos, es decir despojados por quienes vencen en esa invasión.

Una dictadura es una forma autoritaria de gobierno, en el que un solo líder ejerce formas violentas de control sobre la sociedad que dirige. En una dictadura las personas no pueden elegir quién las gobierna, solo deben aceptar las reglas del dicator. Por ello, la mejor forma de terminar una dictadura es con un movimiento social, con una revolución.

Se le llama discriminación al trato diferente que se da a una persona por motivos de origen, sexo, ideas políticas, religión, etc. Este trato regularmente afecta de manera negativa a quién lo recibe.

$$
\text { Guia para mentoras de Abriendo Oportunidades }{ }^{(3)}
$$


El conjunto de rasgos que nos definen, lo que nos hace ser quienes somos, es nuestra identidad. La forma de hablar, lo que recordamos, lo que nos importa, lo que creemos que es bueno o malo, la forma en que nos vestimos... Una identidad puede ser individual pero es también colectiva, y en esa identidad colectiva están marcados los rasgos de nuestra cultura. La identidad es un conjunto de rasgos compartidos, que nos definen frente a los demás. Estos rasgos se van formando con el tiempo, y por eso tienen que ver con la historia.

Una invasión se refiere al ingreso por la fuerza a un territorio de un grupo de personas que llevan fuerzas militares, armas e ideas diferentes que se imponen. Esto se hace buscando el poder y tomando las tierras y los bienes sin estar de acuerdo las dos partes. Una invasión es violenta, no solamente por las armas, si no por las ideas y las estructuras sociales que se forman para los invadidos.

Una organización social es un grupo de personas que se relacionan entre sí, y que juntos cumplen con ciertos objetivos. Por ejemplo, gente que se organiza por la educación, los gobiernos, las familias mismas, los grupos religiosos, etc. Se trata de la vida colectiva, de la organización y el orden que esa vida produce, de lo que se busca estando juntos en un mismo espacio o en un mismo objetivo.

Un país es un territorio, un conjunto de leyes y una población que conforman una unidad política. En ese sentido, los países no son fijos, no son parte de la naturaleza: son creaciones, invenciones, formas que adoptamos para la vida social.

Cuando se piensa que un tipo de persona o una cultura es superior a otra se llama racismo, y esta dinámica crea una diferencia de vida para las personas que se supone son inferiores. El racismo es un error y es un hecho violento. No hay culturas o etnias que sean superiores a otras, solo son diferentes, y eso lejos de ser un problema es una gran fortaleza.

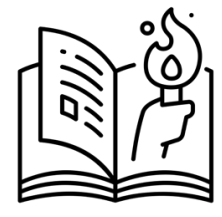

Una revolución es un cambio profundo, y generalmente violento, en las estructuras políticas y económicas de una sociedad. A veces, cuando los pueblos participan en ellas, esos cambios pueden ayudarles a mejorar sus condiciones de vida. Pero cuando eso no sucede, las cosas pueden empeorar. La palabra revolución también tiene que ver con el movimiento. El diccionario nos enseña que una revolución también es un giro, una vuelta sobre nuestro propio eje. Así funcionan los motores, las bicicletas, los molinos: sus piezas giran, se mueven y permiten avanzar. ¿̇Y qué queremos nosotras, como comunidad? Precisamente eso: avanzar, movernos, transformarnos y vivir mejor. 
Los seres humanos vivimos en espacios compartidos, de lo más pequeño a lo mayor, y esa vida conjunta se llama sociedad. En una sociedad hay cierto orden y reglas que hacen que sea una sola. También hay ciertos rasgos que se comparten, como las estructuras de gobierno, las organizaciones comunitarias, pero sobre todo el espacio geográfico que ocupa; un espacio compartido en el que las personas atraviesan la historia, el orden y los gestos culturales.

Un triunvirato es cuando tres personas gobiernan un país. En Guatemala los ha habido de forma dictatorial, y también como medida inmediata cuando algo muy grande a sacudido las formas de gobierno, como una revolución.

Un virreinato es una división territorial que es parte de un reino, pero que se encuentra lejos de ese reino, por lo que es gobernado por un virrey, quien es el representante del rey. Un virreinato es el mismo reino pero con cierta distancia geográfica y también con ciertas autonomías. El virreinato más cercano que tuvimos durante la época colonial en Guatemala fue el Virreinato de la Nueva España, cuya sede estuvo en la actual Ciudad de México. 


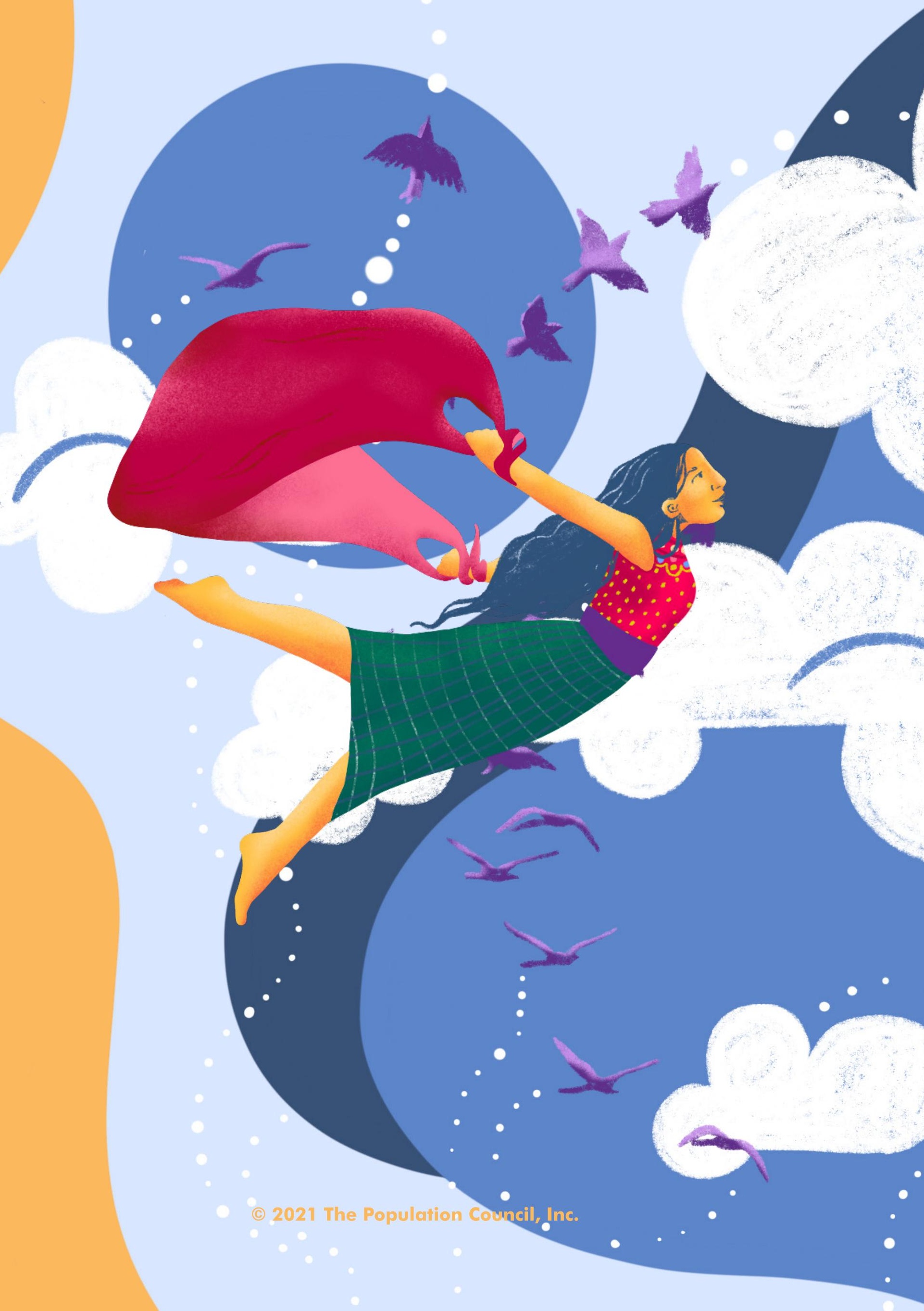

